\title{
Temporal Variability in the Quality of Produced Water from Wells Tapping the Ozark Aquifer of Southeast Kansas
}

\author{
P. Allen Macfarlane \\ Kansas Geological Survey
}

\begin{abstract}
State and local agencies have become concerned that the available water supply from the Ozark aquifer in the Tri-state region of southeast Kansas, southwest Missouri, and northeastern Oklahoma may become unusable or require additional water treatment because of deteriorating quality resulting from overdevelopment. Many southwest Missouri and southeast Kansas water supplies withdraw water from a 30-60-mi (48-96-km)-wide transition zone in the Ozark aquifer that separates calcium, magnesium-bicarbonate ground water with low dissolved solids to the east from sodium-chloride brines to the west. Water-quality deterioration within the transition zone could potentially come about as a result of eastward migration or upward movement from deeper horizons of saline water. This study assessed variability in the quality of water produced from wells within the transition zone in southeast Kansas across a variety of time scales. Water samples were collected monthly from nine wells located in the transition zone over a two-year period and frequently during two $50+$ hr chemicalquality pumping tests of Pittsburg well 8. The samples were analyzed for conductance and $\mathrm{pH}$, and all major and selected minor dissolved inorganic constituents. Mixing curves of chloride versus bicarbonate/chloride ratio and chloride versus sodium/chloride ratio demonstrate that the produced water from Ozark aquifer wells is a mixture of low dissolved solids, calcium, magnesium-bicarbonate ground waters and sodium-chloride brines. Produced water from wells tapping sources in the Ozark and the overlying Springfield Plateau aquifers is a blend of waters from these sources, although the data suggest that the contribution from the Springfield is small relative to the Ozark aquifer. Fluctuations in the quality of the produced water during pumping most likely result from complex mixing of waters of differing quality from different parts of the Ozark aquifer within the well bore. This is borne out by bicarbonate/chloride ratio versus chloride concentration mixing curves and the dissolved constituent ratios indicative of bicarbonate and sodium in excess of that required to balance calcium + magnesium and chloride, respectively. Comparison of the 1979-1980 data with the 2006-08 data from this project indicates that the chloride concentration in some of the sampled supplies has increased. Based on extrapolation of the maximum estimated rate of chloride concentration increase, the earliest that water from Pittsburg wells 8 and 10 would exceed the recommended drinking water limit for chloride is estimated to be by the years 2045 and 2060, respectively, assuming continuation of the present rates of pumping.
\end{abstract}

\section{Introduction}

The Ozark aquifer is the single most important source of water in the Tri-state region of southeast Kansas, southwest Missouri, and northeast Oklahoma. Kansas water agencies and the Tri-State Coalition (a multi-state, nongovernmental organization consisting of water-related interest groups) are concerned that the available supply from the Ozark may become inadequate, rendered unusable, or require additional water treatment in the near future because of water-quality degradation. Many southeast Kansas and southwest Missouri water supplies withdraw water from wells that tap a 30-60-mi (48-96-km)-wide transition zone in the Ozark aquifer separating calcium-bicarbonate type ground waters with low dissolved solids to the east from sodium-chloride brines to the west (fig. 1).

Two earlier regional studies indicated significant short- and long-term changes in the chemical quality of produced water from wells within or near the Ozark aquifer transition zone. Darr (1978) used 1966-1976 chloride data collected from public water supplies to infer the eastward movement of brackish water into Barton, Vernon, and Bates counties in southwestern Missouri. Macfarlane and Hathaway (1987) noted increases in the concentrations of sodium and chloride in the water produced from well 1 of the now defunct Crawford County RWD 7 between 1972 and 1980. Long-term pumping from the confined aquifer has significantly reduced and in some areas has reversed the hydraulic head gradient, which is generally from east to west across the water-quality transition zone in the Ozark aquifer. Development has produced coalesced cones of depression on the potentiometric surface within or near the transition zone in the Pittsburg, Kansas, and Miami, Oklahoma, areas (fig. 2; Macfarlane and Hathaway, 1987; Gillip et al., 2007). Macfarlane and Hathaway 


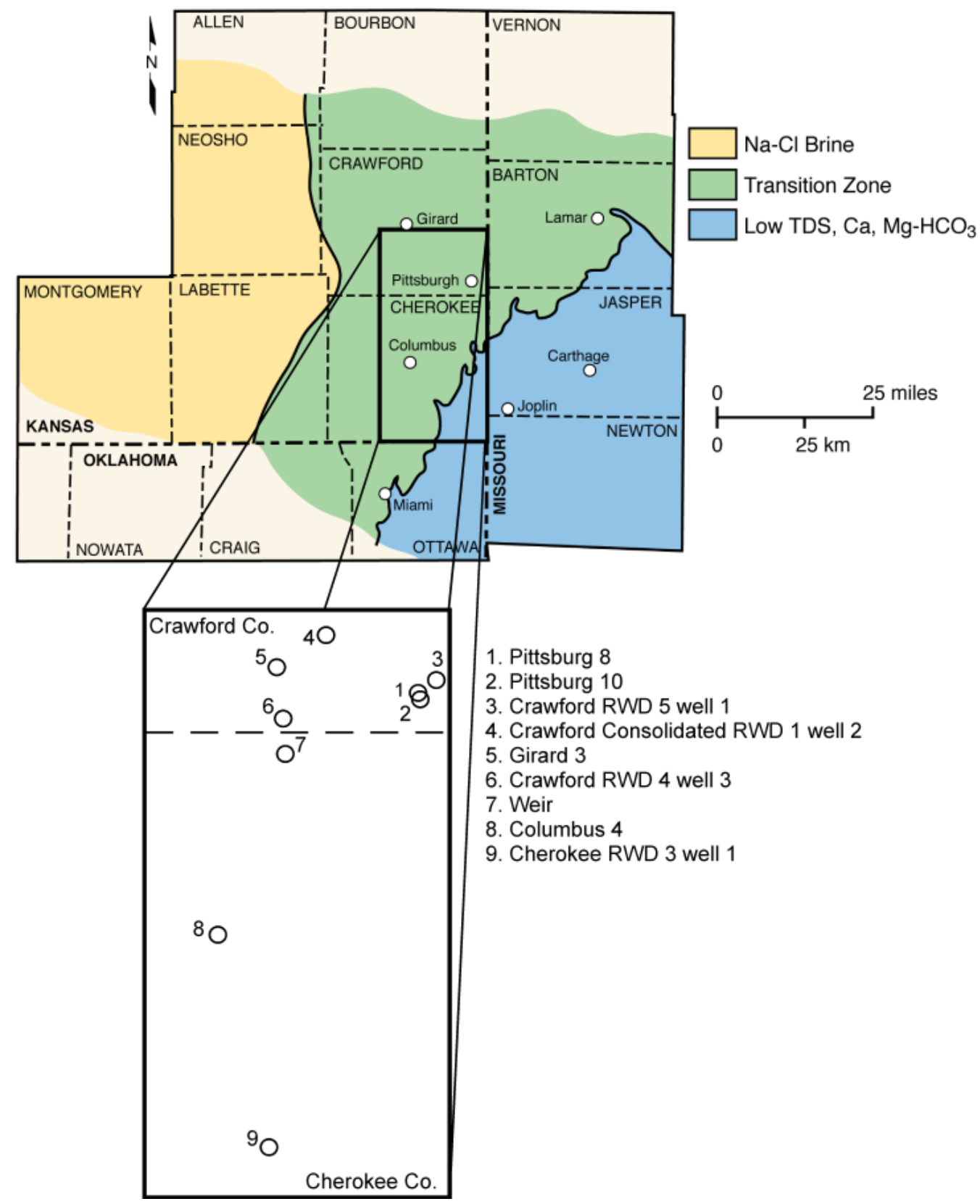

FIGURE 1-Location of the nine supply wells included in this project and Ozark aquifer water-quality provinces within the Tri-state region. The boundary separating the $\mathrm{Na}-\mathrm{Cl}$ brine from the transition zone represents a chloride concentration of 2,500 mg/L, and the line separating the transition zone from the low TDS water is the Pennsylvanian-Mississippian boundary outcrop (Macfarlane and Hathaway, 1987).

(1987) suggested that hydraulic head gradient reversals and increases in the vertical hydraulic head gradient could potentially induce the reported increases in chloride.

To better understand the impact of pumping on water quality, a project was initiated in 2006 that focused on nine public supply wells that withdraw water from the transition zone within the Ozark aquifer in southeast Kansas (fig. 1; table 1). Historic water-quality data were available for six of the nine wells from regional surveys reported in Macfarlane and Hathaway (1987; table 2).
The objectives of the project were to 1 ) characterize the magnitude of fluctuations in the geochemistry of produced water from these wells based on samples collected monthly and repeatedly during the extended pumping of a single well, 2) assess long-term changes in the geochemistry of produced water from these wells since 1979-1980, and 3) use the results to better understand the causes of the shortand long-term changes in the geochemistry of the waters produced from these wells. 


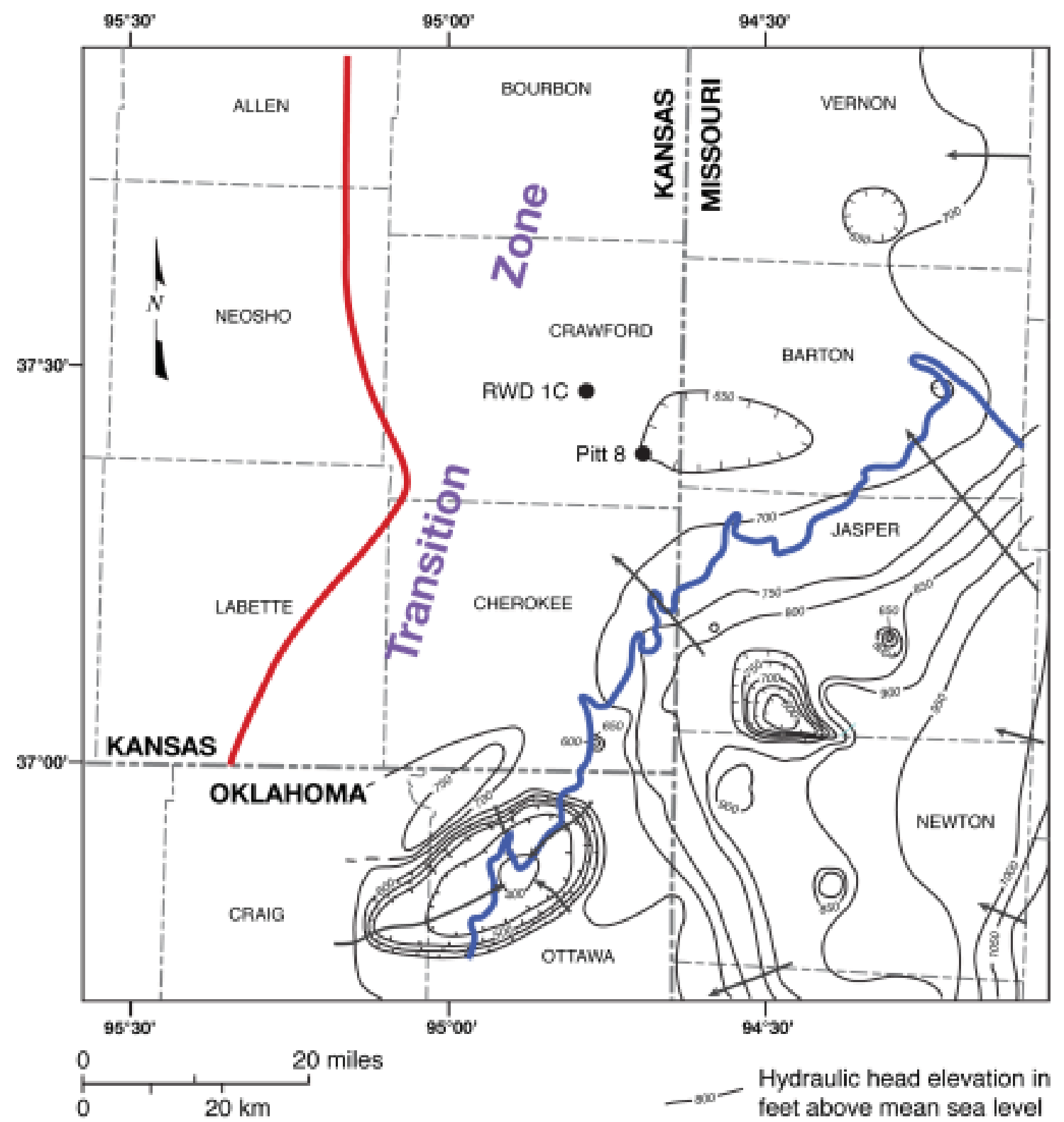

FIGURE 2-The 2006 Ozark aquifer potentiometric surface map of the Tri-state region with the water-quality transition zone in southeast Kansas and southwest Missouri. The heavy red and blue lines define the area of the saltwater to freshwater transition zone. The black dots labeled RWD 1C and Pittsburg 8 are the approximate locations of Crawford Consolidated RWD 1 well 2 and Pittsburg well 8, respectively. From Macfarlane and Hathaway (1987) and Gillip et al. (2007).

\section{Regional Hydrogeology}

The Tri-state region is located astride the boundary between the Ozark Dome in Missouri and the Cherokee basin in Kansas. The bedrock units generally dip westward at approximately $20 \mathrm{ft} / \mathrm{mi}$ (3.75 m/km; figs. 3-4; Macfarlane and Hathaway, 1987). The Ozark Plateaus aquifer system in southeast Kansas and western Missouri consists of karstic and fractured Mississippian, Lower Ordovician, and Upper Cambrian carbonate rock units and has been subdivided into the Springfield Plateau, Ozark, and St. Francois regional aquifers (Jorgensen et al.,
1993; Macfarlane, 2000; table 3). The Springfield Plateau aquifer framework consists of Mississippian limestones and dolomitic limestone, whereas the Ozark consists primarily of Lower Ordovician and Upper Cambrian dolostones with quartzose sandstones most prominently developed within the Roubidoux Formation and at the base of the Gasconade Dolomite. Sandstones of the Roubidoux Formation rest on a regional unconformity developed at the top of the Gasconade Dolomite (Jorgensen et al., 1993). The rocks of the Roubidoux, Gasconade Dolomite, and 
TABLE 1-Water-supply wells sampled in this project.

\begin{tabular}{|c|c|c|c|c|}
\hline Well Name & PLS Location $^{1}$ & $\begin{array}{c}\text { Well Depth } \\
\text { (ft [m]) }\end{array}$ & $\begin{array}{l}\text { Ozark Aquifer } \\
\text { Thickness } \\
\text { Penetrated (ft } \\
\text { [m]) }\end{array}$ & $\begin{array}{c}\text { Source(s) } \\
\text { Tapped }^{2} \\
\end{array}$ \\
\hline Cherokee RWD 3 well 1 & SWSWSE sec. 17, T. 34 S., R. 24 E. & $1,050(320)$ & $530(162)$ & $\mathrm{O}$ \\
\hline Columbus 4 & NENENW sec. 13, T. 32 S., R. 23 E. & $1,785(544)$ & 747 (228) & $\mathrm{S}, \mathrm{O}, \mathrm{SF}$ \\
\hline Crawford Cons. RWD 1 well 2 & SESESE sec. 2, T. 30 S., R. 24 E. & $1,013(309)$ & $348(106)$ & $\mathrm{O}$ \\
\hline Crawford RWD 4 well 3 & NENENE sec. 16, T. 31 S., R. 24 E. & $970(296)$ & $342(104)$ & $\mathrm{O}$ \\
\hline Crawford RWD 5 well 1 & SESWSW sec. 23, T. 30 S., R. 25 E. & 1,045 (319) & 615 (187) & $\mathrm{S}, \mathrm{O}$ \\
\hline Girard 3 & NESENE sec. 21, T. 30 S., R. 24 E. & $1,165(355)$ & 445 (136) & $\mathrm{O}$ \\
\hline Pittsburg 8 & NENESE sec. 28, T. 30 S., R. 25 E. & $1,050(320)$ & $550(168)$ & $\mathrm{O}$ \\
\hline Pittsburg 10 & NESESE sec. 28, T. 30 S., R. 25 E. & $1,052(321)$ & $550(168)$ & $\mathrm{O}$ \\
\hline Weir & SWSESW sec. 27, T. 31 S., R. 24 E. & $920(280)$ & $300(91)$ & $\mathrm{P}, \mathrm{S}, \mathrm{O}$ \\
\hline
\end{tabular}

${ }^{1}$ Public Land Survey

${ }^{2}$ Aquifers sourced by the supply wells: $\mathrm{P}=$ Pennsylvanian, $\mathrm{S}=$ Springfield Plateau, $\mathrm{O}=$ Ozark, and $\mathrm{SF}=\mathrm{St}$. Francois

TABLE 2-Chemical analyses of water samples collected in 1979-1980 from water-supply wells included in this project.

\begin{tabular}{|c|c|c|c|c|c|c|c|c|c|c|}
\hline Well Name & $\begin{array}{c}\text { Date } \\
\text { Sampled }\end{array}$ & $\begin{array}{c}\text { TDS } \\
(\mathrm{mg} / \mathrm{L})\end{array}$ & $\begin{array}{c}\mathrm{Ca} \\
(\mathrm{mg} / \mathrm{L})\end{array}$ & $\begin{array}{c}\mathrm{Mg} \\
(\mathrm{mg} / \mathrm{L})\end{array}$ & $\begin{array}{c}\mathrm{Na} \\
(\mathrm{mg} / \mathrm{L})\end{array}$ & $\begin{array}{c}\mathrm{K} \\
(\mathrm{mg} / \mathrm{L})\end{array}$ & $\begin{array}{c}\mathrm{Sr} \\
(\mathrm{mg} / \mathrm{L})\end{array}$ & $\begin{array}{l}\mathrm{HCO}_{3} \\
(\mathrm{mg} / \mathrm{L})\end{array}$ & $\begin{array}{c}\mathrm{SO}_{4} \\
(\mathrm{mg} / \mathrm{L})\end{array}$ & $\begin{array}{c}\mathrm{Cl} \\
(\mathrm{mg} / \mathrm{L})\end{array}$ \\
\hline \multirow[t]{3}{*}{ Pittsburg 10} & $4 / 18 / 79$ & 577 & 65 & 27 & 48 & 5.0 & 0.79 & 325 & 68 & 38 \\
\hline & 9/26/79 & 601 & 69 & 28 & 54 & 4.1 & 0.73 & 324 & 80 & 41 \\
\hline & $5 / 15 / 80$ & 446 & 62 & 31 & 55 & 4.6 & 0.85 & 326 & 81 & 41 \\
\hline \multirow[t]{3}{*}{ Crawford RWD 5 well 1} & 4/18/79 & 468 & 42 & 19 & 58 & 3.6 & 0.51 & 265 & 21 & 58 \\
\hline & 9/26/79 & 487 & 45 & 19 & 61 & 3.1 & 0.52 & 271 & 27 & 60 \\
\hline & $5 / 14 / 80$ & 365 & 46 & 22 & 62 & 3.8 & 0.56 & 275 & 26 & 58 \\
\hline $\begin{array}{l}\text { Crawford Cons. RWD } 1 \text { well } 2 \\
\text { (Formerly Crawford RWD } 7 \\
\text { well 2) }\end{array}$ & $10 / 7 / 80$ & 625 & 71 & 32 & 111 & 8.9 & 1.37 & 341 & 87 & 135 \\
\hline \multirow[t]{3}{*}{ Weir } & $4 / 19 / 79$ & 546 & 60 & 27 & 43 & 6.0 & 0.95 & 318 & 53 & 37 \\
\hline & 9/24/79 & 567 & 62 & 28 & 51 & 5.0 & 0.86 & 319 & 63 & 37 \\
\hline & $5 / 12 / 80$ & 417 & 58 & 32 & 50 & 5.7 & 1.01 & 319 & 65 & 38 \\
\hline Columbus 4 & 9/25/79 & 743 & 56 & 28 & 123 & 7.3 & 1.42 & 329 & 78 & 119 \\
\hline \multirow[t]{3}{*}{ Cherokee RWD 3 well 1} & 4/19/79 & 594 & 44 & 20 & 115 & 5.5 & 1.07 & 189 & 28 & 191 \\
\hline & 9/20/79 & 644 & 48 & 24 & 126 & 6.1 & 1.19 & 195 & 39 & 204 \\
\hline & $5 / 13 / 80$ & 544 & 46 & 24 & 122 & 6.4 & 1.20 & 195 & 38 & 200 \\
\hline
\end{tabular}

Potosi formations are considered to be the most productive sources of water (Imes and Emmett, 1994). Most of the supply wells sampled in this project withdraw water from only the upper $600 \mathrm{ft}(183 \mathrm{~m})$ of the aquifer and do not extend below the Gasconade (table 1). Dissolution along fractures and bedding planes is the primary process by which secondary permeability has developed in the carbonate rocks, whereas sandstone-matrix permeability depends on the size, sorting, and degree of cementation of the grains (Imes and Emmett, 1994). As a result of these factors, the permeability of the Ozark aquifer is likely to vary over several orders of magnitude across its thickness (Doveton, 1986). Wells in southeast Kansas do not use the St. Francois aquifer as a source of water and as a result very little is known about it.
Ozark Plateaus aquifer system thickness ranges from 1,735 $\mathrm{ft}$ (529 m) in the Joplin, Missouri, area to 1,390 ft (424 m) at Parsons, Kansas (Macfarlane and Hathaway, 1987). The average thickness of the Ozark and Springfield Plateau aquifers is close to $1,000 \mathrm{ft}(305 \mathrm{~m})$ and $350 \mathrm{ft}$ (114 $\mathrm{m}$ ), respectively, within the study area (Imes and Emmett, 1994). The Springfield Plateau aquifer is unconfined across much of southwest Missouri and the southeast corner of Cherokee County, Kansas. Elsewhere, the Ozark Plateaus aquifer system is confined above by a sequence of Carboniferous (Pennsylvanian) shales and limestones and below by rocks of Precambrian age (fig. 4). One or more low-permeability units separate the Springfield Plateau from the Ozark aquifer in southern Crawford and Cherokee counties. Confining-layer thickness is generally less than 


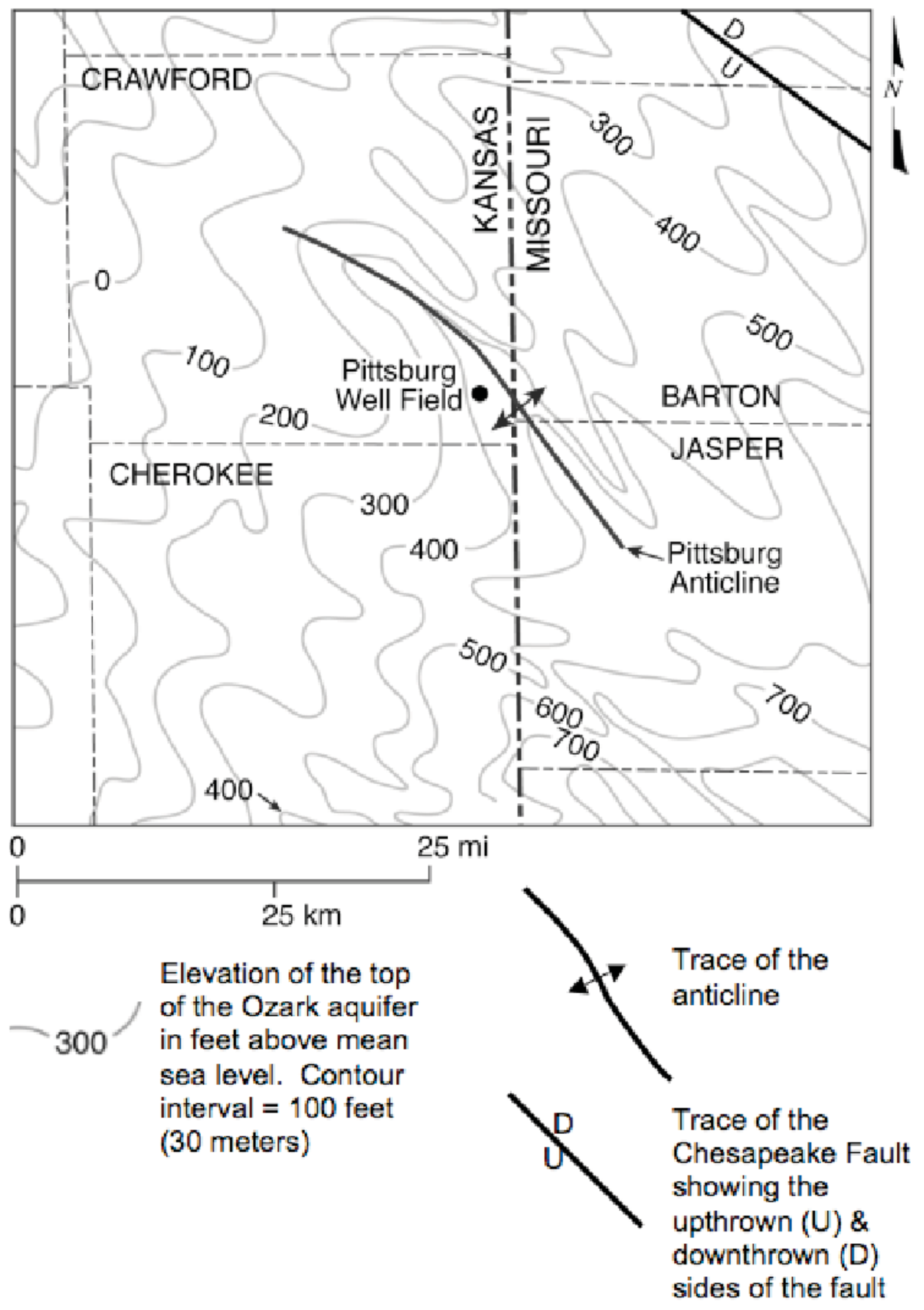

FIGURE 3-Contour map of the elevation of the top of the Ozark aquifer in parts of southeast Kansas and adjacent southwest Missouri showing the location of the Pittsburg well field on the crest of the Pittsburg anticline (from Macfarlane and Hathaway, 1987).

$20 \mathrm{ft}$ (6.1 m) in these counties (Macfarlane and Hathaway, 1987).

Pre-development ground-water flow in both aquifers is generally in a northwesterly direction from southwest Missouri into the southeast Kansas study area (Macfarlane et al., 1981; Imes and Emmett, 1994). Recharge to the confined Ozark aquifer comes primarily from leakage moving downward from the Springfield Plateau aquifer across the confining layer (Imes and Emmett, 1994). Localized concentrations of high-yielding supply wells in northeast Oklahoma, southwest Missouri, and southeast Kansas, including the Pittsburg area, have produced extensive cones of depression in the Ozark aquifer potentiometric surface (fig. 2; Macfarlane et al., 1981; Macfarlane and Hathaway, 1987; Gillip et al., 2007). Declines in the Ozark aquifer potentiometric surface since pre-development exceed $150 \mathrm{ft}(45.7 \mathrm{~m})$ at some locations in the Pittsburg area (Stramel, 1957; Macfarlane and Hathaway, 1987; Gillip et al., 2007). 

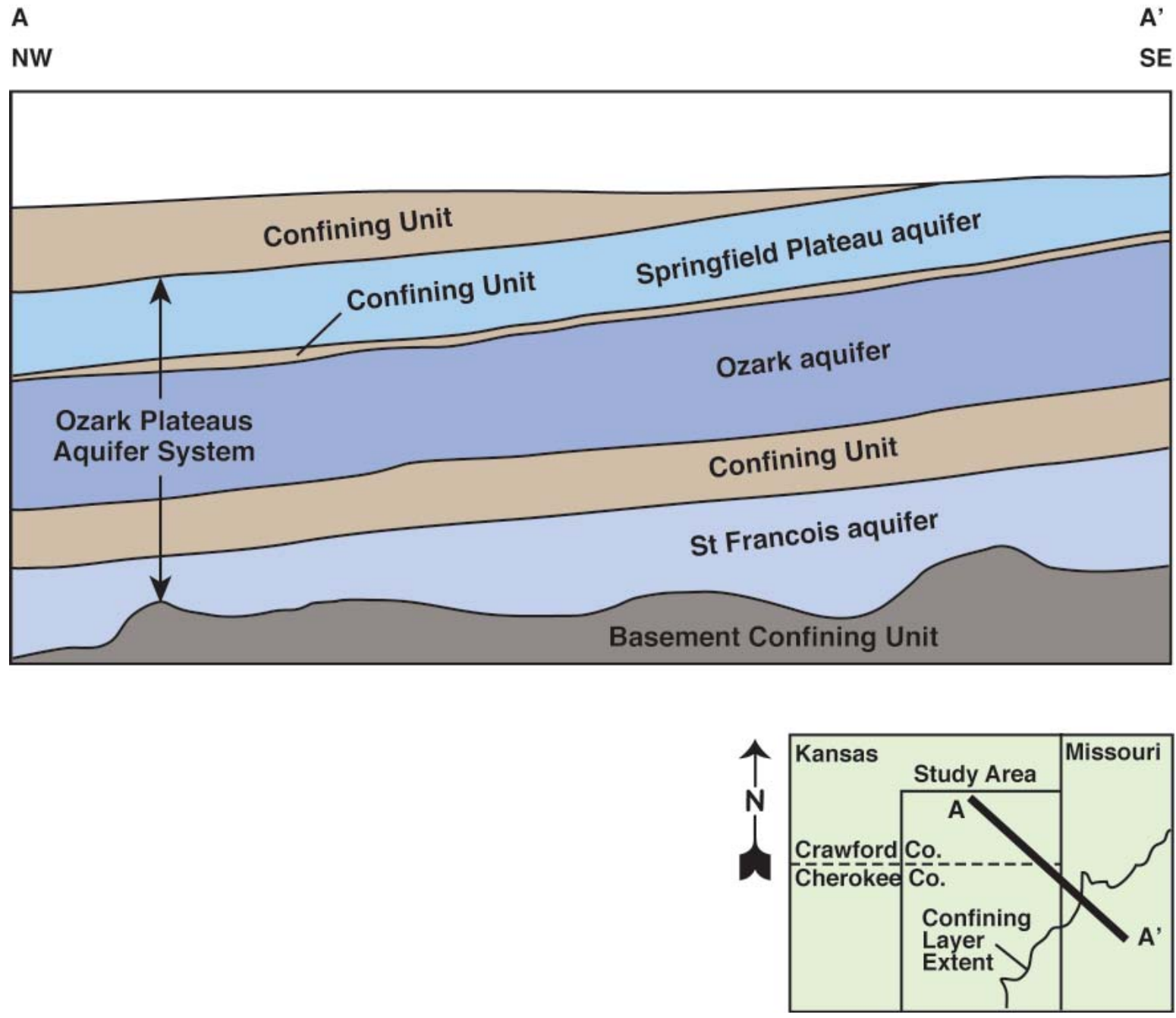

FIGURE 4-Schematic northwest to southeast cross section of the subsurface from southeast Kansas into southwestern Missouri generalized from Macfarlane and Hathaway (1987) showing the arrangement of aquifers and confining units in the Ozark Plateaus aquifer system based on well-log data. The freshwater-transition zone boundary is shown along the top of the figure.

\section{Regional Water Quality}

Where the Springfield Plateau aquifer is unconfined, ground-water quality in the underlying Ozark aquifer varies from calcium-bicarbonate to a mixed cation-bicarbonate type with a total dissolved solids (TDS) concentration of generally less than $500 \mathrm{mg} / \mathrm{L}$ (fig. 1; Macfarlane and Hathaway, 1987). Calcium/magnesium equivalent ratios in Ozark aquifer ground waters are typically $1-2$, consistent with the predominantly dolomitic composition of the aquifer. Ratio values near 3 in water from wells located where the Springfield Plateau is the near-surface aquifer suggest leakage from the limestones of the overlying Springfield Plateau aquifer. The calcium/magnesium equivalent ratio range is from 0.66 to 4.00 with a median value of 1.19 in water from wells in areas of southwestern Missouri where the Springfield Plateau aquifer is overlain by Pennsylvanian strata (Darr, 1978). Water type in the
Springfield Plateau aquifer is generally calcium-bicarbonate with dissolved solids concentrations less than $1,000 \mathrm{mg} / \mathrm{L}$ where the aquifer is unconfined, but changes to a sodiumbicarbonate with dissolved solids concentrations ranging up to several thousand $\mathrm{mg} / \mathrm{L}$ or more where the aquifer is confined by overlying Pennsylvanian strata (Macfarlane and Hathaway, 1987; Feder et al., 1969; Darr, 1978). Dissolved hydrogen sulfide levels are less than $0.2 \mathrm{mg} / \mathrm{L}$.

To the west in the Cherokee basin of southeast Kansas and northeast Oklahoma, the Ozark Plateaus aquifer system is in the deep subsurface and isolated hydraulically from the near-surface sources of freshwater recharge. Here, the ground water in the Ozark aquifer is a sodium-chloride brine with a high TDS concentration that generally exceeds $10,000 \mathrm{mg} / \mathrm{L}$ (fig. 1). The brine environment is chemically reducing and the dissolved hydrogen sulfide concentration 
ranges up to $100 \mathrm{mg} / \mathrm{L}$ where some of the brines are associated with oil fields (Macfarlane and Hathaway, 1987).

Within the transition zone that separates the saline from freshwater in the Ozark aquifer, the ground-water type changes laterally from calcium, magnesium-bicarbonate, and mixed cation-bicarbonate on the east to sodiumchloride on the west (fig. 1). Macfarlane and Hathaway (1987) noted that water samples from wells tapping the Ozark aquifer near the updip edge of the Pennsylvanian outcrop belt exhibited many of the geochemical changes associated with the transition from freshwater to brine. Hence, they set the freshwater-transition zone boundary in the Ozark aquifer to coincide with the updip edge of the Pennsylvanian outcrop belt. The brine/transition zone boundary shown in figs. 1 and 2 was set arbitrarily as the $10,000 \mathrm{mg} / \mathrm{L}$ TDS isocon, the limit that defines usable water in Kansas. Data are not available to determine the vertical variability in water quality from top to bottom within the Ozark aquifer in the transition zone. Based on a review of the data from the drilling of shallower Ozark wells, Macfarlane and Hathaway (1987) concluded that the complexity of the aquifer framework and the regional and local structural fabric probably precludes a simple picture of increasingly saline water with depth within the transition zone.

Water pumped from wells completed in the Ozark aquifer transition zone contains measurable amounts of hydrogen sulfide ranging from trace amounts near the eastern side up to $40 \mathrm{mg} / \mathrm{L}$ near the western side, and sulfate concentrations from $110 \mathrm{mg} / \mathrm{L}$ near the eastern edge to $3 \mathrm{mg} / \mathrm{L}$ near the western edge. The simultaneous occurrence of these constituents in produced water indicates either that 1) a state of chemical equilibrium exists, 2) a very slow transition is occurring in the oxidation state of sulfur in the aquifer, or 3) pumping has produced a disequilibrium blend of waters from different parts of the aquifer (Macfarlane and Hathaway, 1987). Macfarlane et al. (1981) suggested that mixing different amounts of the water from the freshwater and brine sources could approximate the chemistries of water samples from the transition zone of the Ozark aquifer.

\section{Methodology}

Water samples were collected monthly from nine public water-supply wells located within the transition zone in Crawford and Cherokee counties in southeast Kansas (fig. 1; table 1). Newer wells tapping supplies in the Ozark Plateaus aquifer system are steel-cased through the Pennsylvanian to prevent fluids and natural gas from entering the well in the upper part of the boreholes. Below the casing and down to total depth, wells are completed as open boreholes from which water is produced. Five of the monitored wells tap supplies in the Ozark aquifer, and three tap supplies in both the Springfield Plateau and the Ozark aquifers (referred to in this paper as multi-aquifer wells). Of the three multi-aquifer wells, the older Weir city well potentially taps minor sources of water in the overlying Pennsylvanian rocks in addition to the Springfield Plateau and Ozark aquifers.

Water samples were collected in 500-mL polyethylene bottles after the well had been pumped for at least 15 minutes, or after the specific conductance and temperature had stabilized. If the well was running on arrival at the site, the water-supply operator was queried to obtain an estimate of how long the well had been pumping. Most of the time the well had been running for at least one hour prior to sampling. Some of the wells could not be sampled every month because of restrictions on the amount of water that could be pumped or mechanical problems.

Temperature, $\mathrm{pH}$, and specific conductance were measured at the time of sampling. Samples were kept in an ice-chest after collection and later transferred to a refrigerator in the Analytical Services laboratory at the Kansas Geological Survey (KGS).
Water-quality pumping tests were conducted to assess changes in the chemistry of produced water over a single pumping period. Well 8 in the Pittsburg well field was selected for testing because it had been sampled monthly in the previous phase of this research. It is located on the western side of the regional cone of depression in the Ozark aquifer potentiometric surface (fig. 2) and structurally near the crest of the Pittsburg anticline (fig. 3; Macfarlane and Hathaway, 1987). Well 8 is cased through the overlying Springfield Plateau aquifer and was completed as an open borehole from the Jefferson City Dolomite into the upper part of the Gasconade Dolomite (table 3). Water is produced from the well by a turbine pump at the rate 1,875 gal/minute (118 L/second).

In 2008, tests were conducted in late June near the beginning of what is normally a period of high water demand and in early September just after the time of peak demand. The monitoring well hydrograph in fig. 5 shows that the elevation of the potentiometric surface is generally higher during low pumping-stress periods than it is during high pumping-stress conditions. The June test duration was 50.7 hours, during which 26 water samples were collected, and the September test duration was 51.8 hours, during which 28 samples were collected. The interval between samplings varied from 15 minutes to 8.8 hours in the June test and from 30 minutes to 3 hours in the September test.

Samples were refrigerated until processed in the KGS laboratory. Specific conductance and $\mathrm{pH}$ were measured after the samples had equilibrated to room temperature. Samples were then analyzed for calcium, magnesium, strontium, sodium, potassium, bicarbonate, 
TABLE 3-Bedrock and hydrostratigraphic units in the study area modified from Jorgensen et al. (1993).

\begin{tabular}{|c|c|c|c|c|}
\hline System/Subsystem & Series & Rock Unit & \multicolumn{2}{|r|}{ Hydrostratigraphic Unit } \\
\hline Pennsylvanian & Middle Pennsylvanian & $\begin{array}{l}\text { Marmaton Group } \\
\text { Cherokee Group }\end{array}$ & \multicolumn{2}{|r|}{ confining unit } \\
\hline \multirow[b]{2}{*}{ Mississippian } & \multirow[b]{2}{*}{ Undifferentiated } & - & \multirow{6}{*}{ 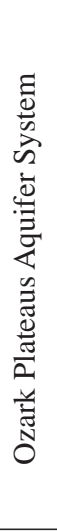 } & Springfield Plateau aquifer \\
\hline & & $\begin{array}{l}\text { Northview Shale } \\
\text { Compton Limestone }\end{array}$ & & confining unit \\
\hline Ordovician & Lower Ordovician & $\begin{array}{l}\text { Jefferson City Dolomite } \\
\text { Roubidoux Formation } \\
\text { Gasconade Dolomite }\end{array}$ & & \multirow{2}{*}{ Ozark aquifer } \\
\hline \multirow{3}{*}{ Cambrian } & \multirow{3}{*}{ Upper Cambrian } & \multirow{3}{*}{$\begin{array}{c}\text { Derby and Doe Run Dolomites } \\
\text { Bonneterre Dolomite } \\
\text { Lamotte Sandstone }\end{array}$} & & \\
\hline & & & & confining unit \\
\hline & & & & St. Francois aquifer \\
\hline Precambrian & - & - & & confining unit \\
\hline
\end{tabular}

sulfate, and chloride. Anion analyses were performed using ion chromatography with a Dionex ICS-3000 and cation concentrations were measured using a Jarrel-Ash ICP. Prior to analysis, samples processed for the Dionex and the Jarrel-Ash were passed through 0.2-micron and 0.45-micron filters, respectively. Bicarbonate was determined using an automated titrimeter. Most of the analytical results are within $2 \%$ of electrical balance based on milliequivalent/liter (meq/L) values, and all of the analyses are within $5 \%$ of balance. TDS concentration was calculated by summing the major and minor constituent concentrations. In the TDS calculation, the bicarbonate concentration was multiplied by $49.17 \%$ to approximate the amount of carbonate that would be left in the residual solids after evaporating to dryness. The analytical results are in tables 4-15. Water-type classification is based on whether the percent meq/L contributions of individual dissolved cations and anions exceed 50\% of the total meq/L concentration of cations or anions. Waters in which none of the constituent concentrations exceed $50 \%$ of the total cations or anions were classified as mixed.

Graphical displays of the concentration data were used to explore spatial and temporal relationships and develop mixing relationships between constituents and constituent ratios that represent the contributions of end-member ground waters of differing chemistry to the produced waters sampled in this project. The diamond-shaped field of the Piper diagram (Piper, 1944) was modified by rotation of the coordinate axes $90^{\circ}$ to allow for easier plotting and display of the monthly sample data from spreadsheets.

Mixing curves are useful for testing the hypothesis that a given water is a mixture of two end-member waters of differing chemistry based on their dissolved constituents. In the case of two end-member mixtures, the relationship between relative amounts and observed end-member concentrations and the mix in a water sample can be expressed as a mass balance equation (Hem, 1985):

$$
C_{1} V_{1}+C_{2} V_{2}=C_{3}\left(V_{1}+V_{2}\right)
$$

where $C_{1}$ and $C_{2}$, and $V_{1}$ and $V_{2}$, are the constituent concentrations and the volumes from sources 1 and 2, respectively, and $C_{3}$ and $\left(V_{1}+V_{2}\right)$ are the constituent concentration and the volume of water produced at the well. In the case of relative contributions, the quantity $\left(V_{1}+\right.$ $V_{2}$ ) is equal to 1 , and $V_{1}$ and $V_{2}$ are volume fractions.

Monthly pumpage data could not be obtained for most of the wells sampled because of the manner in which water withdrawals are tabulated by the water utilities. Some of the utilities rely on sources of both ground water from the Ozark Plateau aquifer system and surface water from Bone Creek Reservoir in Crawford County. Thus, it is difficult to quantify withdrawals from individual wells. However, on the basis of the types of pumps, the pumping rate, and frequency of use information, it is likely that Pittsburg 8 and Girard 3 are used more heavily than any of the other wells in this study. 
A.

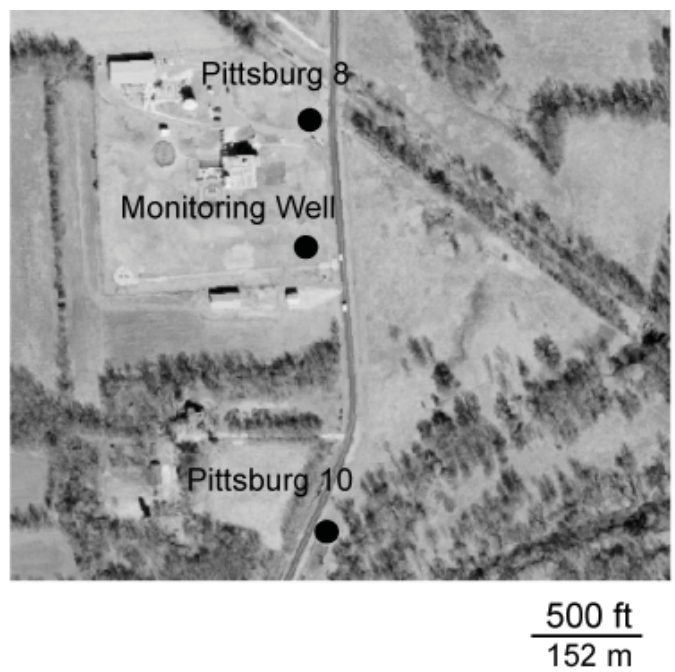

B.

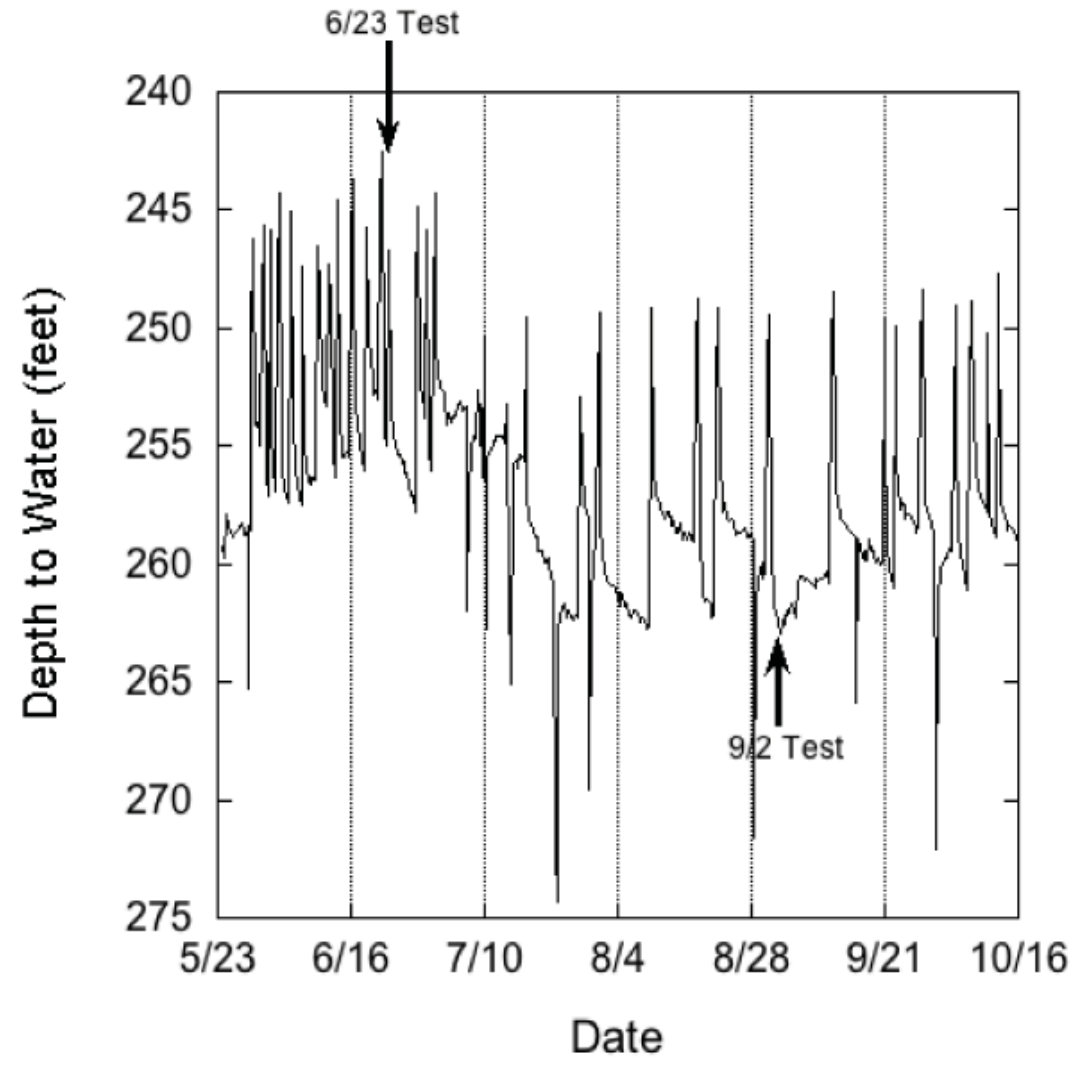

FIGURE 5-(A) Aerial photograph showing the location of the observation well (from which the hydrograph in B was generated) in relation to wells 8 and 10 in the city of Pittsburg, Kansas, field. (B) Hydrograph of the monitoring well completed in the Ozark aquifer in the Pittsburg well field showing depth to water from land surface. The arrows indicate the approximate start time of each chemical-quality pumping test. 


\section{Results}

\section{Monthly Sampling}

The overall trend in the 2006-08 monthly samples from the Ozark and multi-aquifer wells collected during the study reflects spatial and temporal changes in water type across the Ozark transition zone described in Macfarlane and Hathaway (1987) from the 1979-1980 sampling events in the Tri-state region (tables 2, 4-13; fig. 6). Water samples from Pittsburg 8 and 10 and Crawford RWD 4 well 3 in the Ozark aquifer are a mixed cation-bicarbonate type with a TDS range of 478-551 mg/L. In contrast, water samples from the Cherokee County RWD 3 well 1 in the Ozark aquifer are a sodium-chloride type with a TDS range of 541-644 mg/L. In between these chemistries, water samples from Crawford Consolidated RWD 1 well 2 and Girard 3 fall into the mixed cation-mixed anion classification. TDS concentration ranges from 639-674 $\mathrm{mg} / \mathrm{L}$ and 663-721 $\mathrm{mg} / \mathrm{L}$ for the samples collected from Girard 3 and Crawford Consolidated RWD 1 well 2, respectively. The Crawford RWD 5 well 1 and the Weir city well are both multi-aquifer wells. Samples from Crawford RWD 5 well 1 are a mixed cation-bicarbonate type with a TDS range of 516-566 mg/L. Samples from the Weir city well are a mixed cation-bicarbonate type and range from more sodium rich to more calcium and magnesium rich with a TDS range of 396-497 mg/L. In contrast, the water type in the samples from another multi-aquifer well, Columbus 4, varies from a mixed cation-bicarbonate to a sodium-bicarbonate type with a TDS range of 466-617 $\mathrm{mg} / \mathrm{L}$. However, points on fig. 6 for the Columbus well 4 samples with higher bicarbonate and lower sulfate and chloride percentages fall within the ranges of bicarbonate and sulfate and chloride percentages for the other two multi-aquifer wells.

Some of the monthly data sets exhibit linear trends on the modified Piper diagram in fig. 6, while others do not. Vertical trends in the data on fig. 6 for Pittsburg well 8, Crawford Consolidated RWD 1 well 2, and Crawford RWD 4 well 3 indicate that fluctuations in water quality could be primarily attributed to changes in the relative proportions of bicarbonate to sulfate + chloride concentrations in the water from one monthly sampling to the next. The linear trend in the data for Columbus well 4 indicates fluctuations in the relative proportions of both cations and anions, and the horizontal trend in the data for the Weir city well indicates primarily variations in the relative proportions of calcium + magnesium to sodium + potassium. Calcium/magnesium equivalent ratios of waters from all the monitored wells range from about 1.2 to 1.4 .

\section{Changes in Water Quality 1979-1980 to 2006-08}

Six wells that were sampled for water quality in 1979-1980 (table 2) were included in the 2006-08 monthly sampling events (figs. 7-10). Comparison of the Crawford County water analyses from the 2006-08 events with those from 1979-1980 indicates significant changes in the quality and chloride concentrations of water produced by Pittsburg well 10 and Crawford Consolidated RWD No. 1 well 2. These wells are located within a regional cone of depression in the Ozark aquifer potentiometric surface (fig. 2; Macfarlane and Hathaway, 1987; Gillip et al., 2007).

TABLE 4-Water type and TDS concentration range for each of the nine wells sampled monthly from 2006-08.

\begin{tabular}{lccc}
\hline \hline Water Supply Well & Water Type & $\begin{array}{c}\text { TDS Concentration } \\
\text { Range (mg/L) }\end{array}$ & Number of Samples \\
\hline $\begin{array}{l}\text { Cherokee RWD 3 } \\
\text { well 1 } \\
\text { Columbus well 4 }\end{array}$ & Sodium-chloride & $541-644$ & 20 \\
$\begin{array}{l}\text { Crawford Consolidated } \\
\text { RWD 1 well 2 } \\
\text { Crawford RWD 4 } \\
\text { well 3 }\end{array}$ & $\begin{array}{c}\text { Mixed cation-mixed anion } \\
\text { brawford RWD 5 }\end{array}$ & $466-617$ & 19 \\
well 1 & Mixed cation-bicarbonate & $663-721$ & 20 \\
Girard 3 & Mixed cation-bicarbonate & $478-534$ & 20 \\
Pittsburg 8 & Mixed cation-mixed anion & $516-566$ & 20 \\
Pittsburg 10 & Mixed cation-bicarbonate & $639-674$ & 20 \\
Weir & Mixed cation-bicarbonate & $481-551$ & 16 \\
\hline
\end{tabular}




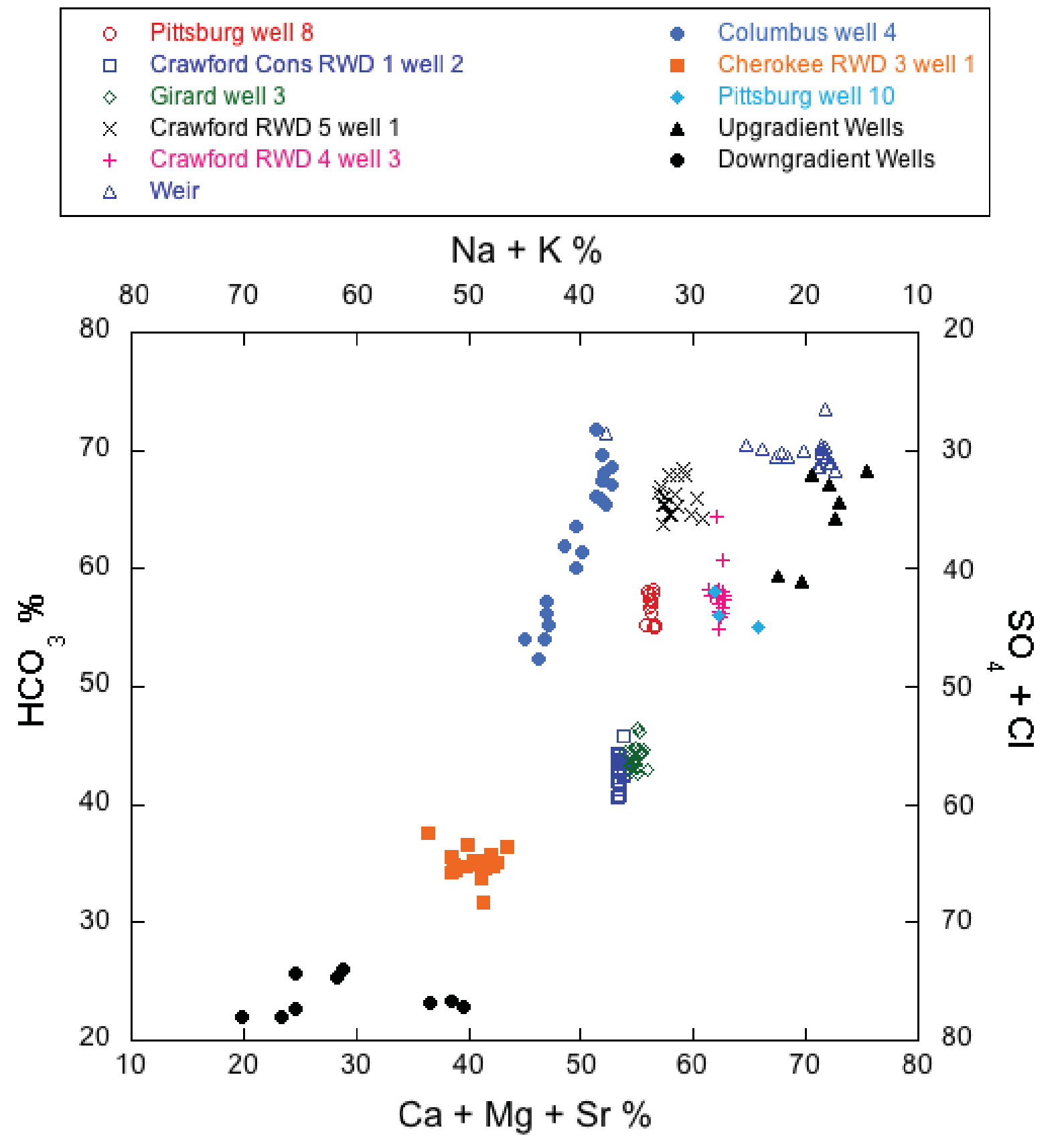

FIGURE 6-Plot of chemical data for the 2006-08 monthly series of water sampling events from the nine wells and for samples from downgradient wells with $>500 \mathrm{mg} / \mathrm{L}$ chloride concentration and for upgradient and downgradient wells sampled in 1980 from Crawford and Cherokee counties on a modified Piper diagram. See Appendix 3 in Macfarlane and Hathaway (1987) for a complete tabulation of the sample analysis data from the upgradient and downgradient wells.

The analyses of water from the Crawford County Consolidated RWD No. 1 well 2 and Pittsburg well 10 (fig. 7) reveal slight changes in the relative amounts of calcium + magnesium + strontium and sodium + potassium but an increase in the relative amount of sulfate + chloride that is more pronounced. In all cases the chloride generally increased more than the sulfate concentration (fig. 9). The average chloride concentration increased by about $50 \mathrm{mg} / \mathrm{L}$ from 1979-1980 to 2006-08 in water from both wells (from 40 to $90.7 \mathrm{mg} / \mathrm{L}$ for Pittsburg well 10 and $135 \mathrm{mg} / \mathrm{L}$ for a single sample from Crawford Consolidated RWD 1 well 2 in 1980 to $180 \mathrm{mg} / \mathrm{L}$ in 2006-08; fig. 9). However, this increase represented a doubling of chloride for the Pittsburg well but only about a 37\% increase for the RWD 


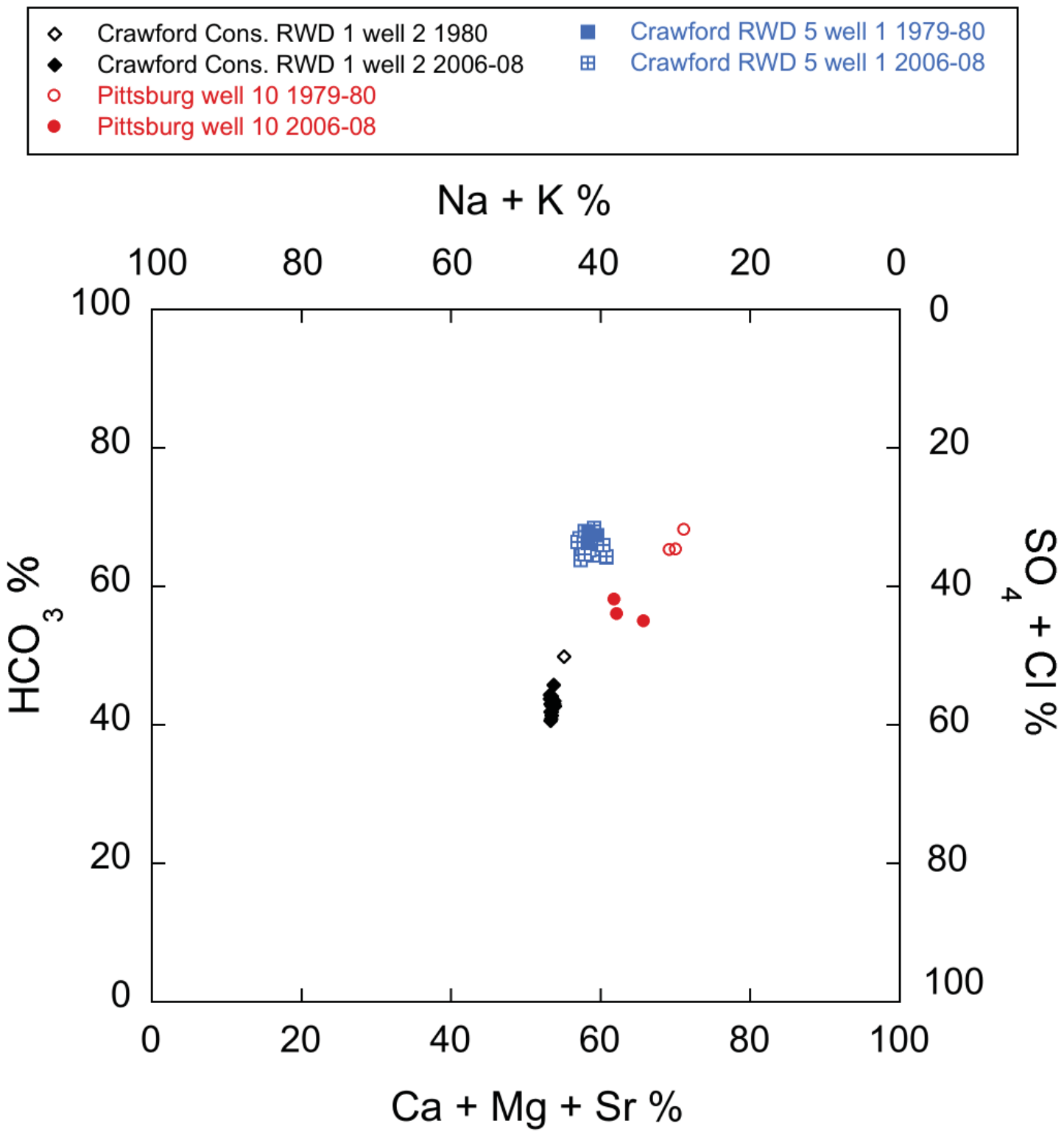

FIGURE 7-Plot of chemical data for the 1979-1980 and 2006-08 monthly series of water sampling events from Crawford County wells on a modified Piper diagram.

well. The average chloride increased for Crawford RWD 5 well 1 by about $11 \mathrm{mg} / \mathrm{L}$ from 1979-1980 to 2006-08 (from an average of $59 \mathrm{mg} / \mathrm{L}$ in 1979-1980 to $68 \mathrm{mg} / \mathrm{L}$ in 200608; fig. 9). The average sulfate concentration apparently did not change from 1979-1980 to 2006-08 for Crawford RWD 5 well 1 and Pittsburg well 10 (from an average of $76 \mathrm{mg} / \mathrm{L}$ in 1979-1980 to $78 \mathrm{mg} / \mathrm{L}$ in 2006-08 in Pittsburg well 10 and from $25 \mathrm{mg} / \mathrm{L}$ to $27 \mathrm{mg} / \mathrm{L}$ in Crawford RWD 5 well 1; fig. 9). Sulfate increased by $9 \mathrm{mg} / \mathrm{L}$ in water from Crawford Consolidated RWD 1 well 2 from 1980 to 2006-08 (from 87 mg/L in a single sample from 1980 to an average of $96 \mathrm{mg} / \mathrm{L}$ in samples from 2006-08; fig. 9).

TDS concentration remained unchanged but the range was narrower for the 2006-08 water samples than for the 1979-1980 samples from Pittsburg well 10 (from 446-601 $\mathrm{mg} / \mathrm{L}$ in 1979-1980 to 516-545 mg/L in 2006-08; fig. 9). The TDS content increased from 365-487 mg/L in 19791980 to 516-566 mg/L in 2006-08 in water from Crawford RWD 5 well 1; fig. 9). The average TDS concentration in water from Crawford Consolidated RWD 1 well 2 is almost $60 \mathrm{mg} / \mathrm{L}$ higher in the 2006-08 water samples than the single sample collected in 1980 (686 mg/L in 2006-08 and $625 \mathrm{mg} / \mathrm{L}$ in 1980 for the single sample; fig. 9).

In Cherokee County, the overall chemical quality of the water from the Weir city well and Cherokee RWD 3 well 1 apparently did not change significantly between 1979-1980 and 2006-08 (fig. 10). Assessment of change in the produced water from Columbus well 4 between 1979-1980 and 2006-08 is difficult because comparisons are being made between a single 1979-1980 analysis 
TABLE 5-Chemical analyses of the monthly 2006-08 samples collected from Cherokee RWD 3 well 1.

\begin{tabular}{|c|c|c|c|c|c|c|c|c|c|c|c|}
\hline $\begin{array}{c}\text { Date } \\
\text { Sampled }\end{array}$ & $\begin{array}{l}\text { Sp. Con. } \\
(\mu S / c m)\end{array}$ & pH & $\begin{array}{c}\text { TDS } \\
\text { (mg/L) }\end{array}$ & $\begin{array}{c}\mathrm{Ca} \\
(\mathrm{mg} / \mathrm{L})\end{array}$ & $\begin{array}{c}\mathrm{Mg} \\
(\mathrm{mg} / \mathrm{L})\end{array}$ & $\begin{array}{c}\mathrm{Na} \\
(\mathrm{mg} / \mathrm{L})\end{array}$ & $\begin{array}{c}\mathrm{K} \\
(\mathrm{mg} / \mathrm{L})\end{array}$ & $\begin{array}{c}\mathrm{Sr} \\
(\mathrm{mg} / \mathrm{L})\end{array}$ & $\begin{array}{l}\mathrm{HCO}_{3} \\
\text { (mg/L) }\end{array}$ & $\begin{array}{c}\mathrm{SO}_{4} \\
(\mathrm{mg} / \mathrm{L})\end{array}$ & $\begin{array}{c}\mathrm{Cl} \\
(\mathrm{mg} / \mathrm{L})\end{array}$ \\
\hline $4 / 13 / 06$ & 1081 & 7.60 & 590 & 44.4 & 21.9 & 136 & 7.5 & 1.32 & 220 & 39.6 & 211 \\
\hline $5 / 15 / 06$ & 1040 & 7.40 & 572 & 46.3 & 22.2 & 134 & 6.4 & 1.26 & 216 & 45.5 & 199 \\
\hline 6/15/06 & 1010 & 7.45 & 559 & 45.9 & 22.3 & 130 & 6.2 & 1.21 & 212 & 43.2 & 195 \\
\hline 7/13/06 & 1067 & 7.83 & 578 & 45.5 & 22.2 & 136 & 6.8 & 1.32 & 221 & 36.8 & 209 \\
\hline 8/15/06 & 1140 & 8.00 & 592 & 44.1 & 21.8 & 142 & 8.3 & 1.38 & 224 & 42.7 & 210 \\
\hline 9/19/06 & 1052 & 8.10 & 570 & 45.7 & 22.1 & 129 & 5.6 & 1.19 & 219 & 44.8 & 203 \\
\hline 10/16/06 & 1021 & 7.52 & 562 & 46.8 & 22.5 & 133 & 6.0 & 1.31 & 209 & 40.0 & 198 \\
\hline 11/21/06 & 1051 & 7.80 & 583 & 46.1 & 22.7 & 134 & 6.3 & 1.27 & 214 & 46.8 & 209 \\
\hline 12/19/06 & 1011 & 8.00 & 564 & 46.5 & 22.6 & 129 & 5.8 & 1.19 & 213 & 42.9 & 200 \\
\hline 1/26/07 & 1072 & 7.80 & 598 & 45.3 & 22.1 & 144 & 7.1 & 1.36 & 223 & 38.4 & 219 \\
\hline $3 / 20 / 07$ & 1137 & 7.90 & 618 & 46.0 & 22.5 & 149 & 6.7 & 1.30 & 239 & 47.2 & 217 \\
\hline $4 / 1 / 07$ & 1159 & 7.80 & 641 & 44.5 & 22.3 & 161 & 7.2 & 1.44 & 263 & 42.8 & 222 \\
\hline $5 / 15 / 07$ & 1163 & 7.95 & 644 & 47.2 & 22.8 & 152 & 7.3 & 1.50 & 243 & 47.5 & 235 \\
\hline $6 / 1 / 07$ & 1036 & 7.80 & 573 & 46.8 & 22.3 & 133 & 6.1 & 1.28 & 215 & 43.4 & 205 \\
\hline $8 / 1 / 07$ & 1031 & 7.34 & 558 & 47.8 & 22.8 & 129 & 6.0 & 1.24 & 210 & 44.5 & 193 \\
\hline 10/1/07 & 1085 & 7.65 & 591 & 47.5 & 22.5 & 137 & 6.8 & 1.37 & 224 & 42.7 & 211 \\
\hline $12 / 1 / 07$ & 1145 & 7.90 & 545 & 49.5 & 23.4 & 129 & 6.0 & 1.23 & 211 & 31.9 & 189. \\
\hline $1 / 04 / 08$ & 931 & 7.40 & 585 & 45.3 & 21.9 & 138 & 6.6 & 1.33 & 233 & 47.3 & 200 \\
\hline $1 / 25 / 08$ & 1015 & 7.41 & 571 & 46.8 & 22.7 & 131 & 6.1 & 1.25 & 222 & 41.9 & 201 \\
\hline 2/28/08 & 1044 & 7.29 & 541 & 47.6 & 22.7 & 136 & 6.4 & 1.32 & 176 & 34.2 & 195 \\
\hline
\end{tabular}

TABLE 6-Chemical analyses of the monthly 2006-08 samples collected from Columbus well 4.

\begin{tabular}{|c|c|c|c|c|c|c|c|c|c|c|c|}
\hline $\begin{array}{c}\text { Date } \\
\text { Sampled } \\
\end{array}$ & $\begin{array}{l}\text { Sp. Con. } \\
(\mu \mathrm{S} / \mathrm{cm})\end{array}$ & pH & $\begin{array}{c}\text { TDS } \\
\text { (mg/L) }\end{array}$ & $\begin{array}{c}\mathrm{Ca} \\
(\mathrm{mg} / \mathrm{L})\end{array}$ & $\begin{array}{c}\mathrm{Mg} \\
(\mathrm{mg} / \mathrm{L})\end{array}$ & $\begin{array}{c}\mathrm{Na} \\
(\mathrm{mg} / \mathrm{L})\end{array}$ & $\begin{array}{c}\mathrm{K} \\
(\mathrm{mg} / \mathrm{L}) \\
\end{array}$ & $\begin{array}{c}\mathrm{Sr} \\
(\mathrm{mg} / \mathrm{L})\end{array}$ & $\begin{array}{l}\mathrm{HCO}_{3} \\
(\mathrm{mg} / \mathrm{L})\end{array}$ & $\begin{array}{c}\mathrm{SO}_{4} \\
(\mathrm{mg} / \mathrm{L})\end{array}$ & $\begin{array}{c}\mathrm{Cl} \\
(\mathrm{mg} / \mathrm{L})\end{array}$ \\
\hline 4/13/06 & 828 & 7.73 & 487 & 48.3 & 24.6 & 93.5 & 6.6 & 1.37 & 356 & 57.6 & 63.2 \\
\hline $5 / 15 / 06$ & 796 & 7.62 & 491 & 49.1 & 24.8 & 91.8 & 5.7 & 1.35 & 361 & 69.7 & 59.1 \\
\hline 6/15/06 & 789 & 7.66 & 477 & 48.5 & 24.2 & 91.4 & 6.0 & 1.36 & 362 & 53.3 & 62.5 \\
\hline 8/15/06 & 966 & 8.00 & 574 & 53.3 & 26.9 & 122 & 7.3 & 1.50 & 350 & 52.6 & 126 \\
\hline 9/19/06 & 872 & 7.85 & 519 & 50.6 & 24.9 & 102 & 5.8 & 1.45 & 357 & 61.8 & 85.1 \\
\hline 10/16/06 & 904 & 7.52 & 536 & 53.2 & 26.3 & 110 & 6.2 & 1.53 & 354 & 59.1 & 93.2 \\
\hline 11/21/06 & 982 & 7.70 & 579 & 52.8 & 26.4 & 122 & 7.0 & 1.49 & 361 & 62.7 & 117 \\
\hline $12 / 19 / 06$ & 726 & 7.65 & 473 & 47.9 & 25.0 & 91.8 & 5.5 & 1.32 & 363 & 46.9 & 64.4 \\
\hline $1 / 26 / 07$ & 866 & 7.85 & 512 & 50.5 & 25.1 & 104 & 6.5 & 1.40 & 364 & 46.5 & 86.5 \\
\hline 3/19/07 & 886 & 7.95 & 496 & 51.5 & 24.9 & 97 & 5.7 & 1.30 & 366 & 55.5 & 69.1 \\
\hline $4 / 1 / 07$ & 1037 & 7.80 & 594 & 54.8 & 27.0 & 127 & 6.6 & 1.59 & 356 & 54.5 & 136 \\
\hline $6 / 1 / 07$ & 815 & 7.70 & 470 & 50.1 & 24.9 & 91.0 & 5.2 & 1.38 & 362 & 47.0 & 61.4 \\
\hline $8 / 1 / 07$ & 980 & 7.20 & 573 & 53.6 & 25.7 & 121 & 7.0 & 1.54 & 361 & 66.3 & 108 \\
\hline 10/1/07 & 1096 & 7.56 & 617 & 57.4 & 27.5 & 134 & 7.6 & 1.65 & 353 & 62.3 & 141 \\
\hline $12 / 1 / 07$ & 1102 & 7.58 & 612 & 55.0 & 27.2 & 137 & 7.0 & 1.59 & 364 & 54.6 & 140 \\
\hline $1 / 04 / 08$ & 787 & 7.45 & 530 & 52.0 & 25.4 & 111 & 6.8 & 1.48 & 362 & 54.7 & 88.8 \\
\hline 1/25/08 & 776 & 7.62 & 466 & 48.7 & 24.6 & 94.4 & 5.7 & 1.37 & 374 & 39.3 & 56.0 \\
\hline 2/28/08 & 806 & 7.42 & 469 & 50.8 & 24.8 & 94.9 & 6.2 & 1.44 & 359 & 43.0 & 59.4 \\
\hline 5/15/08 & 829 & 7.75 & 484 & 51.6 & 25.3 & 93.3 & 5.4 & 1.41 & 361 & 55.1 & 62.3 \\
\hline
\end{tabular}




\begin{tabular}{|llll|}
\hline$\diamond$ & Weir city well 1979-80 & $\circ$ & Cherokee RWD 3 well 1 1979-80 \\
$\bullet$ & Weir city well 2006-08 & $\bullet$ & Cherokee RWD 3 well 1 2006-08 \\
$\square$ & Columbus well 4 1979-80 & & \\
$\square$ & Columbus well 4 2006-08 & & \\
\hline
\end{tabular}

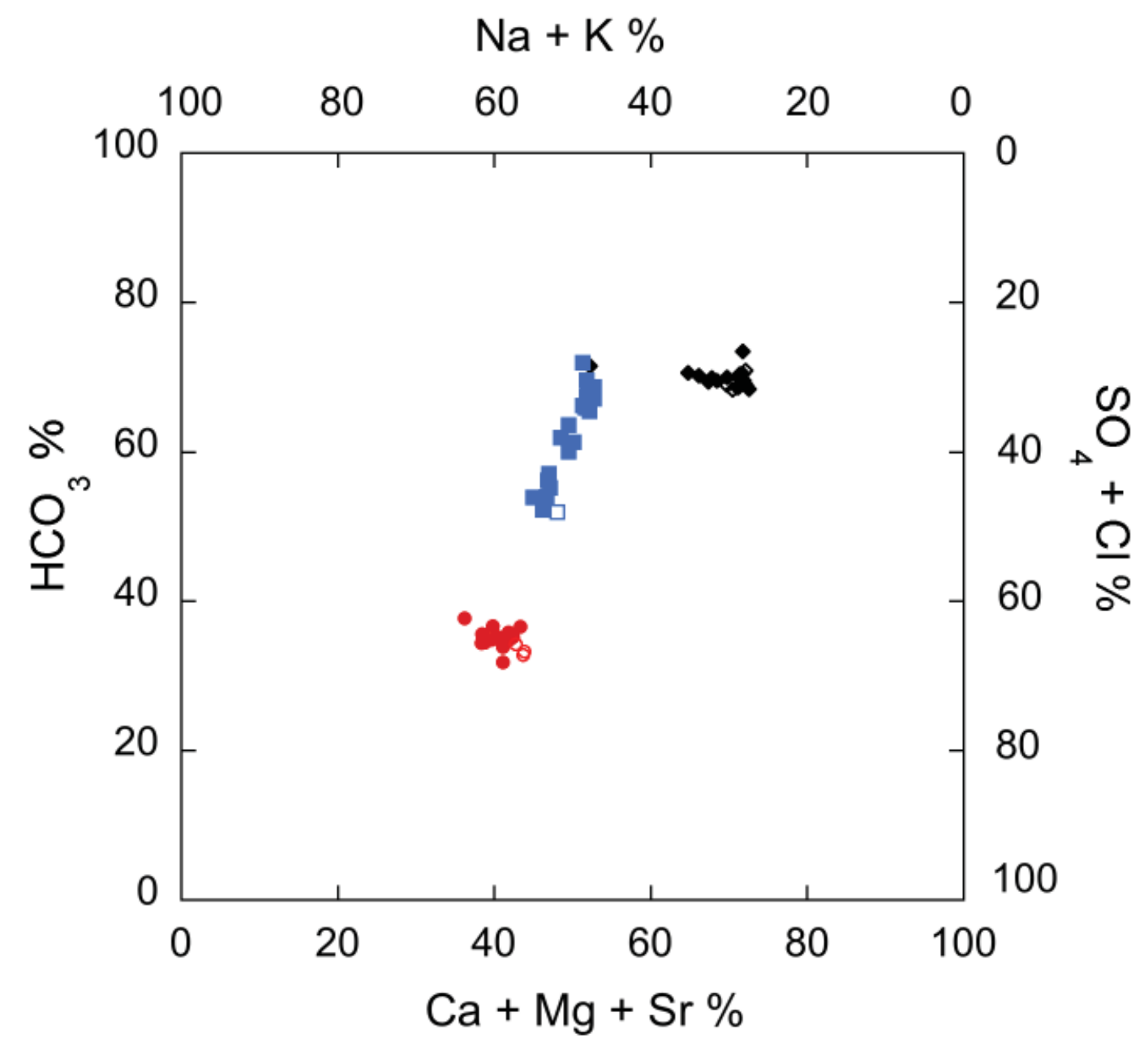

FIGURE 8-Plot of chemical data for the 1979-1980 and 2006-08 monthly series of water sampling events from Cherokee County wells on a modified Piper diagram.

and many 2006-08 analyses that exhibit wide month-tomonth variability in dissolved constituent composition. However, based on the average chloride concentration in 2006-08 for water samples from Columbus well 4, the chloride apparently decreased from the 1979-1980 concentration level (from $119 \mathrm{mg} / \mathrm{L}$ for a single sample in 1979 to an average value of $88.3 \mathrm{mg} / \mathrm{L}$ in 2006-08; fig. $10)$. The change in the average chloride concentration in water from the Weir city well is within analytical error (from $37.3 \mathrm{mg} / \mathrm{L}$ in $1979-1980$ to $38.5 \mathrm{mg} / \mathrm{L}$ in 2006-08; fig. 10). The average chloride concentration in water from Cherokee RWD 3 well 1 increased slightly from 198 mg/L in 1979-1980 to $206 \mathrm{mg} / \mathrm{L}$ in 2006-08 (about 4\%; fig. 10). The largest change in the average sulfate concentration occurred in Columbus well 4 where it decreased about 30\% from $78 \mathrm{mg} / \mathrm{L}$ in a single sample in 1979 to an average concentration of $54.9 \mathrm{mg} / \mathrm{L}$ (fig. 10). The change in the average sulfate concentration in water from the Weir city well is within analytical error (from $60 \mathrm{mg} / \mathrm{L}$ in 1979-1980 to $61.4 \mathrm{mg} / \mathrm{L}$ in 2006-08; fig. 10). However, the average sulfate concentration in water from Cherokee RWD 3 well 1 increased from $35 \mathrm{mg} / \mathrm{L}$ in 1979-1980 to $42.2 \mathrm{mg} / \mathrm{L}$ in 2006-08 (about 20\%; fig. 10).

Average TDS concentrations decreased in water from all Cherokee County wells, with the largest average decrease of about 30\% in Columbus well 4 (from 743 $\mathrm{mg} / \mathrm{L}$ in a single sample collected in 1979 to an average concentration of $524 \mathrm{mg} / \mathrm{L}$ in the 2006-08 samples; fig. 10). The average TDS concentration in water from the Weir city well decreased by about $16 \%$ between the 1979-1980 and 2006-08 series of sampling events (from $510 \mathrm{mg} / \mathrm{L}$ in 1979-1980 to $426 \mathrm{mg} / \mathrm{L}$ in 2006-08; fig. 10). A much 
TABLE 7-Chemical analyses of the monthly 2006-08 samples collected from Crawford RWD 4 well 3.

\begin{tabular}{|c|c|c|c|c|c|c|c|c|c|c|c|}
\hline $\begin{array}{c}\text { Date } \\
\text { Sampled }\end{array}$ & $\begin{array}{l}\text { Sp. Con. } \\
(\mu \mathrm{S} / \mathrm{cm})\end{array}$ & pH & $\begin{array}{c}\text { TDS } \\
(\mathrm{mg} / \mathrm{L})\end{array}$ & $\begin{array}{c}\mathrm{Ca} \\
(\mathrm{mg} / \mathrm{L})\end{array}$ & $\begin{array}{c}\mathrm{Mg} \\
(\mathrm{mg} / \mathrm{L})\end{array}$ & $\begin{array}{c}\mathrm{Na} \\
(\mathrm{mg} / \mathrm{L})\end{array}$ & $\begin{array}{c}\mathrm{K} \\
(\mathrm{mg} / \mathrm{L})\end{array}$ & $\begin{array}{c}\mathrm{Sr} \\
(\mathrm{mg} / \mathrm{L})\end{array}$ & $\begin{array}{l}\mathrm{HCO}_{3} \\
\text { (mg/L) }\end{array}$ & $\begin{array}{c}\mathrm{SO}_{4} \\
(\mathrm{mg} / \mathrm{L})\end{array}$ & $\begin{array}{c}\mathrm{Cl} \\
(\mathrm{mg} / \mathrm{L})\end{array}$ \\
\hline $4 / 13 / 06$ & 917 & 7.32 & 511 & 64.9 & 31.0 & 78.1 & 9.9 & 1.15 & 337 & 72.9 & 86.2 \\
\hline $5 / 15 / 06$ & 907 & 7.41 & 534 & 68.4 & 32.2 & 80.6 & 7.7 & 1.22 & 332 & 80.2 & 99.3 \\
\hline 6/15/06 & 886 & 7.25 & 508 & 67.8 & 31.7 & 79.9 & 6.7 & 1.20 & 329 & 80.0 & 78.4 \\
\hline 7/13/06 & 905 & 7.46 & 506 & 64.0 & 30.5 & 76.0 & 7.1 & 1.13 & 335 & 79.8 & 82.0 \\
\hline 8/15/06 & 910 & 7.75 & 514 & 65.7 & 32.1 & 78.0 & 6.6 & 1.14 & 329 & 83.2 & 84.8 \\
\hline 9/19/06 & 919 & 7.95 & 522 & 66.5 & 31.6 & 78.5 & 5.7 & 1.17 & 333 & 88.8 & 85.1 \\
\hline 10/16/06 & 892 & 7.53 & 505 & 67.6 & 31.9 & 79.5 & 5.6 & 1.19 & 327 & 76.6 & 80.9 \\
\hline 11/20/06 & 918 & 7.45 & 524 & 66.2 & 31.5 & 78.4 & 5.7 & 1.17 & 333 & 88.7 & 87.7 \\
\hline $12 / 18 / 06$ & 912 & 7.55 & 518 & 67.2 & 33.0 & 79.2 & 6.3 & 1.17 & 335 & 81.9 & 83.7 \\
\hline $1 / 25 / 07$ & 901 & 7.45 & 517 & 68.3 & 31.9 & 80.5 & 6.5 & 1.19 & 330 & 79.5 & 85.6 \\
\hline 3/19/07 & 916 & 7.60 & 519 & 68.1 & 31.2 & 79.6 & 6.4 & 1.10 & 334 & 80.9 & 86.8 \\
\hline $4 / 1 / 07$ & 914 & 7.50 & 511 & 66.8 & 31.5 & 77.8 & 6.0 & 1.21 & 334 & 75.5 & 86.7 \\
\hline $5 / 14 / 07$ & 958 & 7.45 & 512 & 67.7 & 31.5 & 78.8 & 6.2 & 1.22 & 331 & 77.2 & 85.4 \\
\hline $6 / 1 / 07$ & 908 & 7.45 & 519 & 67.3 & 30.8 & 78.7 & 6.3 & 1.19 & 331 & 85.5 & 85.6 \\
\hline $8 / 1 / 07$ & 907 & 6.97 & 518 & 68.3 & 31.5 & 80.5 & 6.7 & 1.22 & 334 & 83.0 & 81.5 \\
\hline $10 / 1 / 07$ & 1319 & 7.26 & 517 & 68.2 & 31.4 & 80.4 & 6.6 & 1.21 & 337 & 79.4 & 83.1 \\
\hline $12 / 1 / 07$ & 925 & 7.21 & 504 & 71.2 & 33.6 & 83.2 & 6.7 & 1.26 & 336 & 60.8 & 81.4 \\
\hline $1 / 04 / 08$ & 773 & 7.13 & 515 & 68.0 & 29.7 & 80.1 & 6.5 & 1.18 & 334 & 83.6 & 80.4 \\
\hline $1 / 25 / 08$ & 875 & 7.16 & 513 & 67.8 & 31.0 & 80.1 & 6.5 & 1.20 & 331 & 77.8 & 84.5 \\
\hline $2 / 27 / 08$ & 893 & 6.82 & 478 & 67.9 & 31.5 & 80.4 & 6.7 & 1.21 & 337 & 58.9 & 64.7 \\
\hline
\end{tabular}

TABLE 8-Chemical analyses of the monthly 2006-08 samples collected from Crawford RWD 5 well 1.

\begin{tabular}{|c|c|c|c|c|c|c|c|c|c|c|c|}
\hline $\begin{array}{c}\text { Date } \\
\text { Sampled } \\
\end{array}$ & $\begin{array}{l}\text { Sp. Con. } \\
(\mu \mathrm{S} / \mathrm{cm})\end{array}$ & $\mathbf{p H}$ & $\begin{array}{c}\text { TDS } \\
(\mathrm{mg} / \mathrm{L})\end{array}$ & $\begin{array}{c}\mathrm{Ca} \\
(\mathrm{mg} / \mathrm{L})\end{array}$ & $\begin{array}{c}\mathrm{Mg} \\
(\mathrm{mg} / \mathrm{L})\end{array}$ & $\begin{array}{c}\mathrm{Na} \\
(\mathrm{mg} / \mathrm{L})\end{array}$ & $\begin{array}{c}\mathrm{K} \\
(\mathrm{mg} / \mathrm{L})\end{array}$ & $\begin{array}{c}\mathrm{Sr} \\
(\mathrm{mg} / \mathrm{L})\end{array}$ & $\begin{array}{l}\mathrm{HCO}_{3} \\
(\mathrm{mg} / \mathrm{L})\end{array}$ & $\begin{array}{c}\mathrm{SO}_{4} \\
(\mathrm{mg} / \mathrm{L})\end{array}$ & $\begin{array}{c}\mathrm{Cl} \\
(\mathrm{mg} / \mathrm{L})\end{array}$ \\
\hline $4 / 13 / 06$ & 680 & 7.62 & 545 & 46.9 & 21.0 & 66.7 & 4.3 & 0.64 & 291 & 26.7 & 69.7 \\
\hline 5/15/06 & 665 & 7.54 & 531 & 47.1 & 20.8 & 63.7 & 4.3 & 0.63 & 287 & 32.1 & 65.0 \\
\hline 6/15/06 & 660 & 7.40 & 538 & 46.9 & 21.0 & 65.5 & 4.0 & 0.64 & 290 & 26.1 & 73.4 \\
\hline 7/13/06 & 680 & 7.70 & 516 & 48.4 & 21.3 & 59.7 & 3.8 & 0.62 & 275 & 29.4 & 67.3 \\
\hline 8/15/06 & 651 & 7.90 & 520 & 47.1 & 21.2 & 61.0 & 4.2 & 0.61 & 279 & 27.9 & 68.5 \\
\hline 9/19/06 & 709 & 7.95 & 538 & 47.0 & 20.7 & 64.2 & 3.4 & 0.63 & 293 & 32.0 & 67.1 \\
\hline 10/16/06 & 662 & 7.42 & 523 & 49.4 & 21.5 & 61.1 & 3.2 & 0.63 & 279 & 31.3 & 66.8 \\
\hline $11 / 20 / 06$ & 692 & 7.60 & 556 & 48.0 & 21.6 & 69.3 & 3.9 & 0.66 & 296 & 30.8 & 74.7 \\
\hline 12/18/06 & 682 & 7.80 & 540 & 46.4 & 21.0 & 66.9 & 4.0 & 0.64 & 295 & 29.2 & 66.3 \\
\hline $1 / 25 / 07$ & 684 & 7.65 & 544 & 47.0 & 21.7 & 68.5 & 4.0 & 0.64 & 296 & 18.6 & 77.2 \\
\hline 3/19/07 & 691 & 7.80 & 541 & 47.1 & 20.9 & 66.8 & 4.1 & 0.60 & 293 & 31.4 & 66.8 \\
\hline $4 / 1 / 07$ & 675 & 7.60 & 525 & 49.0 & 21.9 & 62.3 & 3.6 & 0.64 & 286 & 22.4 & 69.0 \\
\hline $5 / 14 / 07$ & 705 & 7.75 & 535 & 48.4 & 21.2 & 67.6 & 3.9 & 0.67 & 285 & 31.1 & 67.6 \\
\hline $6 / 1 / 07$ & 694 & 8.00 & 541 & 49.2 & 21.6 & 70.7 & 4.0 & 0.69 & 296 & 19.2 & 70.6 \\
\hline $8 / 1 / 07$ & 685 & 7.16 & 546 & 48.0 & 21.1 & 69.6 & 4.2 & 0.68 & 297 & 31.1 & 64.2 \\
\hline $10 / 1 / 07$ & 686 & 7.45 & 566 & 48.9 & 22.4 & 65.9 & 3.9 & 0.64 & 319 & 29.5 & 65.6 \\
\hline $12 / 1 / 07$ & 692 & 7.51 & 534 & 49.7 & 21.7 & 69.3 & 4.1 & 0.68 & 293 & 22.5 & 63.4 \\
\hline $1 / 04 / 08$ & 579 & 7.22 & 525 & 48.0 & 20.9 & 65.7 & 3.8 & 0.65 & 285 & 29.1 & 62.9 \\
\hline $1 / 25 / 08$ & 654 & 7.28 & 527 & 48.5 & 21.4 & 65.8 & 3.8 & 0.66 & 292 & 22.9 & 63.4 \\
\hline $2 / 27 / 08$ & 660 & 7.10 & 522 & 48.4 & 21.3 & 64.0 & 4.0 & 0.64 & 290 & 22.8 & 60.9 \\
\hline
\end{tabular}

Current Research in Earth Sciences, Bulletin 258, part 3 (http://www.kgs.ku.edu/Current/2010/Macfarlane/index.html) 
A
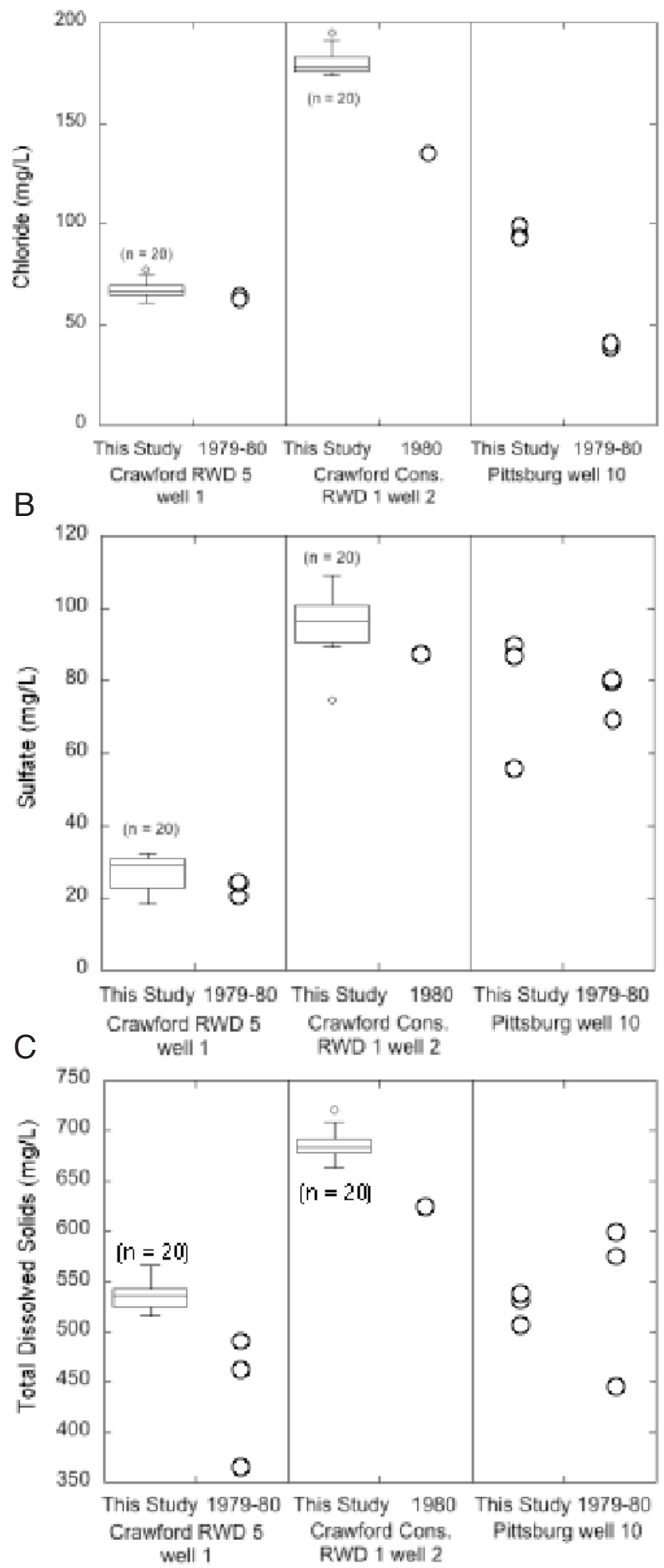

FIGURE 9-Box plot comparing the chloride, sulfate, and TDS concentrations of the 1979-1980 and 2006-08 water samples from wells in Crawford County. smaller decrease in TDS concentration occurred in water from Cherokee RWD 3 well 1 from 594 mg/L in 19791980 to 582 mg/L from 2006-08 (fig. 10).

In general, the temporal chemical variations in water from individual wells represented on figs. 6-8 are smaller than the spatial chemical differences in water from the various wells. The grouping of all of the Ozark aquifer wells in southeast Kansas for which points are plotted on these figures is substantially different from the grouping of the sodium-bicarbonate type waters for wells in the Springfield Plateaus aquifer and of the sodium-chloride brines just to the west. Figure 6 includes points for waters from the Ozark Plateaus aquifer in Crawford and Cherokee counties that contained $>500 \mathrm{mg} / \mathrm{L}$ when sampled during 1980; these points illustrate the trend towards lower bicarbonate and combined divalent cation (calcium, magnesium, and strontium) percentages and higher chloride and sulfate and monovalent cation (sodium and potassium) percentages. The points for these saline waters, Cherokee RWD 3 well 1, and Columbus 4 form a trend representing the mixing of ground water substantially affected by the Na-Cl type brine with freshwater of mixed cationbicarbonate type. The group of points for the other wells in fig. 6 sampled in 2006-08 form a general trend of mixed cation-bicarbonate type waters with generally decreasing sodium and chloride concentrations that parallels the trend for the saline ground waters to Cherokee RWD 3 well 1 and Columbus well 4 freshwaters, but that is shifted to higher divalent cation percentages.

\section{Chemical Quality Pumping Tests}

Calcium, magnesium, sodium, and potassium concentrations decreased slowly with time in the June and September 2008 chemical-quality pumping tests for Pittsburg well 8 (fig. 11). In about the first 10 hours of both tests, the calcium/magnesium equivalent ratio fluctuated and then stabilized at approximately 1.34 until the end of the test. The bicarbonate concentration remained around $319 \mathrm{mg} / \mathrm{L} \pm 6 \mathrm{mg} / \mathrm{L}$ and $318 \mathrm{mg} / \mathrm{L} \pm 2 \mathrm{mg} / \mathrm{L}$ throughout the June and September tests, respectively. In the June test, the chloride and sulfate concentrations both generally decreased rapidly in the early part and then more gradually later in the test. In the September test, the chloride decreased during the first 10 hours of pumping and then leveled off at approximately $105 \mathrm{mg} / \mathrm{L}$ with some small fluctuation for the remainder of the test, while sulfate decreased slowly throughout the test. In both tests, the sulfate/chloride mass ratio trended towards lower values over time (fig. 12). In the June test, the sulfate/chloride ratio was in the range of 0.5 at the beginning of the test, but, in the September test, that ratio was somewhat less than 0.5 for most of the early part of that test. The bicarbonate/chloride mass ratio increased throughout the pumping period in the June test, but, in the September test, the ratio increased only during the first 10 hours and then 
TABLE 9-Chemical analyses of the monthly 2006-08 samples collected from Crawford Consolidated RWD 1 well 2.

\begin{tabular}{|c|c|c|c|c|c|c|c|c|c|c|c|}
\hline $\begin{array}{c}\text { Date } \\
\text { Sampled } \\
\end{array}$ & $\begin{array}{l}\text { Sp. Con. } \\
(\mu \mathrm{S} / \mathrm{cm})\end{array}$ & pH & $\begin{array}{c}\text { TDS } \\
(\mathrm{mg} / \mathrm{L})\end{array}$ & $\begin{array}{c}\mathrm{Ca} \\
(\mathrm{mg} / \mathrm{L})\end{array}$ & $\begin{array}{c}\mathrm{Mg} \\
(\mathrm{mg} / \mathrm{L})\end{array}$ & $\begin{array}{c}\mathrm{Na} \\
(\mathrm{mg} / \mathrm{L})\end{array}$ & $\begin{array}{c}\mathrm{K} \\
(\mathrm{mg} / \mathrm{L}) \\
\end{array}$ & $\begin{array}{c}\mathrm{Sr} \\
(\mathrm{mg} / \mathrm{L})\end{array}$ & $\begin{array}{c}\mathrm{HCO}_{3} \\
\text { (mg/L) }\end{array}$ & $\begin{array}{c}\mathrm{SO}_{4} \\
(\mathrm{mg} / \mathrm{L})\end{array}$ & $\begin{array}{c}\mathrm{Cl} \\
(\mathrm{mg} / \mathrm{L})\end{array}$ \\
\hline $4 / 13 / 06$ & 1247 & 6.97 & 684 & 74.8 & 34.8 & 130 & 6.1 & 1.51 & 331 & 97.6 & 176 \\
\hline $5 / 15 / 06$ & 1247 & 7.06 & 686 & 76.1 & 35.2 & 128 & 7.4 & 1.48 & 323 & 99.9 & 178 \\
\hline 6/15/06 & 1248 & 7.24 & 663 & 75.8 & 35.3 & 130 & 7.9 & 1.49 & 291 & 89.8 & 179 \\
\hline 7/13/06 & 1233 & 7.31 & 689 & 75.3 & 35.2 & 129 & 7.5 & 1.48 & 334 & 91.1 & 184 \\
\hline 8/15/06 & 1188 & 7.50 & 677 & 75.3 & 34.6 & 128 & 6.8 & 1.47 & 326 & 89.3 & 181 \\
\hline 9/19/06 & 1229 & 7.50 & 688 & 74.3 & 34.8 & 127 & 6.7 & 1.46 & 325 & 106 & 177 \\
\hline 10/16/06 & 1211 & 7.24 & 676 & 75.8 & 35.5 & 129 & 6.8 & 1.49 & 323 & 92.1 & 176 \\
\hline $11 / 20 / 06$ & 1250 & 7.30 & 679 & 74.0 & 34.5 & 127 & 6.9 & 1.45 & 326 & 96.5 & 178 \\
\hline 12/18/06 & 1136 & 7.45 & 708 & 76.6 & 35.4 & 131 & 7.0 & 1.50 & 330 & 102 & 191 \\
\hline $1 / 25 / 07$ & 1223 & 7.30 & 682 & 75.6 & 34.6 & 130 & 7.4 & 1.45 & 324 & 90.5 & 183 \\
\hline 3/19/07 & 1239 & 7.45 & 684 & 77.0 & 34.3 & 130 & 7.2 & 1.50 & 330 & 97.0 & 174 \\
\hline $4 / 1 / 07$ & 1255 & 7.20 & 721 & 77.0 & 35.3 & 131 & 7.1 & 1.54 & 334 & 109 & 195 \\
\hline $5 / 14 / 07$ & 1270 & 7.35 & 694 & 76.7 & 35.3 & 132 & 7.0 & 1.55 & 321 & 92.9 & 190 \\
\hline $6 / 1 / 07$ & 1137 & 7.35 & 680 & 77.6 & 35.1 & 132 & 7.1 & 1.56 & 328 & 89.4 & 176 \\
\hline 8/1/07 & 1225 & 6.87 & 695 & 77.6 & 35.0 & 132 & 7.4 & 1.57 & 334 & 101 & 175 \\
\hline $10 / 1 / 07$ & 1245 & 6.93 & 681 & 74.6 & 34.1 & 125 & 7.0 & 1.49 & 327 & 97.8 & 180 \\
\hline $12 / 1 / 07$ & 1261 & 7.18 & 672 & 78.2 & 36.0 & 132 & 7.4 & 1.57 & 336 & 74.7 & 176 \\
\hline 1/04/08 & 1055 & 7.09 & 676 & 77.6 & 35.6 & 133 & 7.5 & 1.56 & 294 & 101 & 175 \\
\hline 1/25/08 & 1195 & 7.06 & 704 & 77.6 & 35.5 & 132 & 7.1 & 1.55 & 332 & 102 & 183 \\
\hline 2/27/08 & 1221 & 6.60 & 690 & 77.8 & 35.4 & 133 & 7.5 & 1.56 & 335 & 95.9 & 174 \\
\hline
\end{tabular}

TABLE 10—Chemical analyses of the monthly 2006-08 and other samples collected from Girard well 3.

\begin{tabular}{|c|c|c|c|c|c|c|c|c|c|c|c|}
\hline $\begin{array}{c}\text { Date } \\
\text { Sampled }\end{array}$ & $\begin{array}{l}\text { Sp. Con. } \\
(\mu \mathrm{S} / \mathrm{cm})\end{array}$ & pH & $\begin{array}{c}\text { TDS } \\
(\mathrm{mg} / \mathrm{L})\end{array}$ & $\begin{array}{c}\mathrm{Ca} \\
(\mathrm{mg} / \mathrm{L})\end{array}$ & $\begin{array}{c}\mathrm{Mg} \\
(\mathrm{mg} / \mathrm{L})\end{array}$ & $\begin{array}{c}\mathrm{Na} \\
(\mathrm{mg} / \mathrm{L})\end{array}$ & $\begin{array}{c}\mathrm{K} \\
(\mathrm{mg} / \mathrm{L})\end{array}$ & $\begin{array}{c}\mathrm{Sr} \\
(\mathrm{mg} / \mathrm{L})\end{array}$ & $\begin{array}{l}\mathrm{HCO}_{3} \\
(\mathrm{mg} / \mathrm{L})\end{array}$ & $\begin{array}{c}\mathrm{SO}_{4} \\
(\mathrm{mg} / \mathrm{L})\end{array}$ & $\begin{array}{c}\mathrm{Cl} \\
(\mathrm{mg} / \mathrm{L})\end{array}$ \\
\hline $4 / 13 / 06$ & 1157 & 7.34 & 639 & 71.0 & 33.0 & 113 & 7.4 & 1.33 & 323 & 90.0 & 153 \\
\hline $5 / 15 / 06$ & 1165 & 7.48 & 654 & 69.9 & 33.1 & 118 & 7.4 & 1.31 & 315 & 88.4 & 163 \\
\hline 6/15/06 & 1112 & 7.30 & 674 & 72.9 & 32.9 & 113 & 7.3 & 1.36 & 314 & 99.0 & 153 \\
\hline 7/13/06 & 1171 & 7.47 & 661 & 74.7 & 34.1 & 120 & 7.5 & 1.34 & 324 & 90.7 & 164 \\
\hline 8/15/06 & 1108 & 7.65 & 656 & 72.3 & 33.2 & 115 & 7.2 & 1.33 & 313 & 98.9 & 155 \\
\hline 9/19/06 & 1183 & 7.19 & 672 & 75.9 & 35.2 & 118 & 7.0 & 1.45 & 320 & 101 & 172 \\
\hline 10/16/06 & 1144 & 7.62 & 651 & 74.4 & 33.9 & 118 & 6.3 & 1.35 & 313 & 95.2 & 155 \\
\hline $11 / 20 / 06$ & 1189 & 7.45 & 655 & 74.0 & 33.6 & 120 & 6.6 & 1.33 & 318 & 92.8 & 169 \\
\hline $12 / 18 / 06$ & 1145 & 7.65 & 656 & 75.4 & 34.9 & 121 & 7.0 & 1.38 & 320 & 97.2 & 179 \\
\hline $1 / 25 / 07$ & 1184 & 7.60 & 661 & 75.5 & 33.2 & 122 & 6.9 & 1.33 & 314 & 92.1 & 175 \\
\hline 3/19/07 & 1181 & 7.80 & 673 & 75.7 & 33.1 & 120 & 6.8 & 1.30 & 320 & 95.6 & 165 \\
\hline $4 / 1 / 07$ & 1164 & 7.45 & 663 & 77.6 & 34.0 & 122 & 7.1 & 1.43 & 319 & 109 & 164 \\
\hline $5 / 14 / 07$ & 1221 & 7.60 & 639 & 75.3 & 34.1 & 123 & 6.5 & 1.39 & 309 & 90.2 & 168 \\
\hline $6 / 1 / 07$ & 1176 & 7.60 & 654 & 76.2 & 33.6 & 121 & 6.7 & 1.39 & 315 & 94.5 & 165 \\
\hline $8 / 1 / 07$ & 1162 & 6.95 & 654 & 76.1 & 34.1 & 122 & 7.0 & 1.43 & 320 & 96.9 & 160 \\
\hline $10 / 1 / 07$ & 1199 & 7.14 & 656 & 75.0 & 33.3 & 119 & 6.7 & 1.35 & 321 & 95.2 & 172 \\
\hline $10 / 1 / 07$ & 1204 & 7.20 & 639 & 76.5 & 34.3 & 124 & 6.9 & 1.39 & 322 & 96.5 & 174 \\
\hline 10/1/07 & 1157 & 7.09 & 654 & 77.0 & 34.1 & 119 & 7.1 & 1.44 & 326 & 102 & 161 \\
\hline $12 / 1 / 07$ & 1203 & 7.33 & 674 & 78.9 & 35.2 & 124 & 7.0 & 1.43 & 321 & 68.9 & 164 \\
\hline $1 / 04 / 08$ & 991 & 7.30 & 661 & 76.4 & 34.0 & 120 & 7.0 & 1.40 & 319 & 99.3 & 159 \\
\hline $1 / 25 / 08$ & 1116 & 7.28 & 656 & 74.9 & 33.7 & 117 & 6.8 & 1.40 & 321 & 101 & 160 \\
\hline 2/27/08 & 1164 & 6.97 & 672 & 76.1 & 33.7 & 123 & 7.0 & 1.39 & 321 & 94.7 & 161 \\
\hline
\end{tabular}


TABLE 11—Chemical analyses of the monthly 2006-08 and other samples collected from Pittsburg well 8.

\begin{tabular}{|c|c|c|c|c|c|c|c|c|c|c|c|}
\hline $\begin{array}{c}\text { Date } \\
\text { Sampled }\end{array}$ & $\begin{array}{l}\text { Sp. Con. } \\
(\mu \mathrm{S} / \mathrm{cm})\end{array}$ & pH & $\begin{array}{c}\text { TDS } \\
(\mathrm{mg} / \mathrm{L})\end{array}$ & $\begin{array}{c}\mathrm{Ca} \\
(\mathrm{mg} / \mathrm{L})\end{array}$ & $\begin{array}{c}\mathrm{Mg} \\
(\mathrm{mg} / \mathrm{L})\end{array}$ & $\begin{array}{c}\mathrm{Na} \\
(\mathrm{mg} / \mathrm{L})\end{array}$ & $\begin{array}{c}\mathrm{K} \\
(\mathrm{mg} / \mathrm{L})\end{array}$ & $\begin{array}{c}\mathrm{Sr} \\
(\mathrm{mg} / \mathrm{L})\end{array}$ & $\begin{array}{l}\mathrm{HCO}_{3} \\
(\mathrm{mg} / \mathrm{L})\end{array}$ & $\begin{array}{c}\mathrm{SO}_{4} \\
(\mathrm{mg} / \mathrm{L})\end{array}$ & $\begin{array}{c}\mathrm{Cl} \\
(\mathrm{mg} / \mathrm{L})\end{array}$ \\
\hline 4/13/06 & 875 & 7.41 & 499 & 57.4 & 26.1 & 87.4 & 5.2 & 0.95 & 318 & 50.1 & 97.5 \\
\hline 5/15/06 & 911 & 7.43 & 517 & 61.4 & 27.9 & 90.7 & 6.6 & 0.97 & 315 & 56.1 & 107 \\
\hline 6/15/06 & 857 & 7.42 & 495 & 58.3 & 26.5 & 88.9 & 5.3 & 0.95 & 316 & 45.8 & 103 \\
\hline 7/13/06 & 897 & 7.47 & 509 & 59.1 & 26.9 & 88.8 & 6.1 & 0.95 & 322 & 47.0 & 111 \\
\hline 8/15/06 & 854 & 7.80 & 503 & 58.5 & 27.2 & 90.0 & 5.5 & 0.94 & 311 & 42.3 & 115 \\
\hline 9/19/06 & 913 & 7.75 & 516 & 59.2 & 27.0 & 88.9 & 4.6 & 0.95 & 319 & 57.9 & 109 \\
\hline 11/20/06 & 965 & 7.15 & 551 & 64.6 & 30.5 & 98.0 & 5.7 & 1.02 & 318 & 61.6 & 122 \\
\hline $12 / 18 / 06$ & 907 & 7.75 & 514 & 59.3 & 27.5 & 90.3 & 5.0 & 0.95 & 319 & 46.4 & 117 \\
\hline $1 / 25 / 07$ & 894 & 7.60 & 512 & 59.2 & 26.9 & 91.4 & 5.1 & 0.95 & 316 & 49.6 & 112 \\
\hline 3/19/07 & 900 & 7.60 & 515 & 59.7 & 26.5 & 89.1 & 5.2 & 0.90 & 319 & 55.2 & 110 \\
\hline 3/20/07 & 883 & 7.95 & 498 & 59.0 & 26.2 & 88.5 & 4.9 & 0.90 & 319 & 47.2 & 103 \\
\hline 3/20/07 & 882 & 7.80 & 506 & 58.6 & 26.0 & 87.7 & 5.0 & 0.90 & 318 & 54.4 & 106 \\
\hline $4 / 1 / 07$ & 889 & 7.50 & 484 & 56.1 & 25.7 & 85.0 & 4.7 & 0.93 & 319 & 38.6 & 106 \\
\hline $5 / 14 / 07$ & 904 & 7.60 & 494 & 58.7 & 26.2 & 88.1 & 4.9 & 0.96 & 315 & 42.6 & 107 \\
\hline $10 / 1 / 07$ & 955 & 7.72 & 542 & 74.8 & 32.0 & 78.1 & 6.0 & 1.07 & 335 & 82.2 & 92.4 \\
\hline $12 / 1 / 07$ & 991 & 7.24 & 535 & 65.6 & 29.9 & 92.6 & 5.2 & 1.01 & 319 & 49.2 & 125 \\
\hline $12 / 1 / 07$ & 958 & 7.26 & 519 & 63.5 & 28.9 & 92.4 & 5.2 & 1.01 & 319 & 44.7 & 116 \\
\hline $12 / 1 / 07$ & 933 & 7.31 & 510 & 62.0 & 28.4 & 91.3 & 5.1 & 0.99 & 320 & 42.9 & 112 \\
\hline $12 / 1 / 07$ & 918 & 7.31 & 506 & 62.6 & 28.2 & 92.6 & 5.2 & 1.00 & 319 & 41.0 & 108 \\
\hline $12 / 1 / 07$ & 903 & 7.35 & 498 & 61.1 & 27.6 & 91.6 & 5.3 & 0.99 & 320 & 38.9 & 104 \\
\hline $1 / 25 / 08$ & 754 & 7.17 & 503 & 59.4 & 26.0 & 89.8 & 5.2 & 0.97 & 314 & 53.2 & 103 \\
\hline $1 / 25 / 08$ & 858 & 7.31 & 500 & 58.7 & 26.0 & 88.5 & 4.9 & 0.96 & 319 & 48.0 & 106 \\
\hline 2/27/08 & 873 & 7.13 & 481 & 57.8 & 26.0 & 87.7 & 5.1 & 0.95 & 321 & 37.5 & 97.2 \\
\hline 2/27/08 & 874 & 7.17 & 495 & 57.9 & 26.3 & 88.3 & 5.2 & 0.96 & 323 & 45.3 & 101 \\
\hline 2/27/08 & 875 & 7.21 & 493 & 58.3 & 26.6 & 89.2 & 5.2 & 0.97 & 321 & 44.8 & 98.9 \\
\hline 2/27/08 & 875 & 7.13 & 506 & 58.8 & 26.7 & 89.9 & 5.2 & 0.98 & 322 & 53.2 & 102 \\
\hline 2/27/08 & 872 & 7.16 & 495 & 58.6 & 26.5 & 89.4 & 5.1 & 0.97 & 322 & 45.5 & 99.4 \\
\hline 2/27/08 & 875 & 7.18 & 502 & 60.2 & 27.3 & 91.8 & 5.3 & 1.00 & 322 & 45.5 & 102 \\
\hline 2/27/08 & 874 & 7.16 & 488 & 57.5 & 26.2 & 88.0 & 5.2 & 0.96 & 318 & 45.0 & 98.3 \\
\hline $2 / 28 / 08$ & 869 & 7.16 & 495 & 58.7 & 26.5 & 89.7 & 5.3 & 0.98 & 320 & 45.7 & 100 \\
\hline 2/28/08 & 874 & 7.16 & 498 & 59.0 & 26.7 & 90.3 & 5.3 & 0.98 & 321 & 45.5 & 101 \\
\hline 2/28/08 & 873 & 7.20 & 494 & 58.2 & 26.4 & 88.9 & 5.2 & 0.97 & 322 & 45.4 & 99.5 \\
\hline 2/28/08 & 873 & 7.18 & 499 & 59.3 & 26.8 & 91.0 & 5.3 & 0.99 & 321 & 45.2 & 101 \\
\hline
\end{tabular}

TABLE 12 - Chemical analyses of the monthly 2006-07 samples collected from Pittsburg well 10. Water from this well was sampled when Pittsburg well 8 was unavailable.

\begin{tabular}{rccccccccrrr}
\hline \hline $\begin{array}{c}\text { Date } \\
\text { Sampled }\end{array}$ & $\begin{array}{c}\text { Sp. Con. } \\
(\mu \mathrm{S} / \mathbf{c m})\end{array}$ & $\mathbf{p H}$ & $\begin{array}{c}\text { TDS } \\
(\mathbf{m g} / \mathbf{L})\end{array}$ & $\begin{array}{c}\mathbf{C a} \\
(\mathbf{m g} / \mathbf{L})\end{array}$ & $\begin{array}{c}\mathbf{M g} \\
(\mathbf{m g} / \mathbf{L})\end{array}$ & $\begin{array}{c}\mathbf{N a} \\
(\mathbf{m g} / \mathbf{L})\end{array}$ & $\begin{array}{c}\mathbf{K} \\
(\mathbf{m g} / \mathbf{L})\end{array}$ & $\begin{array}{c}\text { Sr } \\
(\mathbf{m g} / \mathbf{L})\end{array}$ & $\begin{array}{c}\mathbf{H C O}_{3} \\
(\mathbf{m g} / \mathbf{L})\end{array}$ & $\begin{array}{c}\mathbf{S O}_{4} \\
(\mathbf{m g} / \mathbf{L})\end{array}$ & $\begin{array}{c}\mathbf{C l} \\
(\mathbf{m g} / \mathbf{L})\end{array}$ \\
\hline $10 / 16 / 06$ & 873 & 7.23 & 516 & 59.2 & 27.0 & 88.9 & 4.6 & 0.95 & 319 & 57.9 & 109 \\
$6 / 1 / 07$ & 910 & 7.40 & 537 & 75.0 & 32.3 & 73.3 & 5.6 & 0.99 & 327 & 90.3 & 88.9 \\
$8 / 1 / 07$ & 934 & 6.96 & 545 & 75.2 & 32.4 & 78.4 & 6.0 & 1.07 & 333 & 86.3 & 90.8 \\
\hline
\end{tabular}


A.

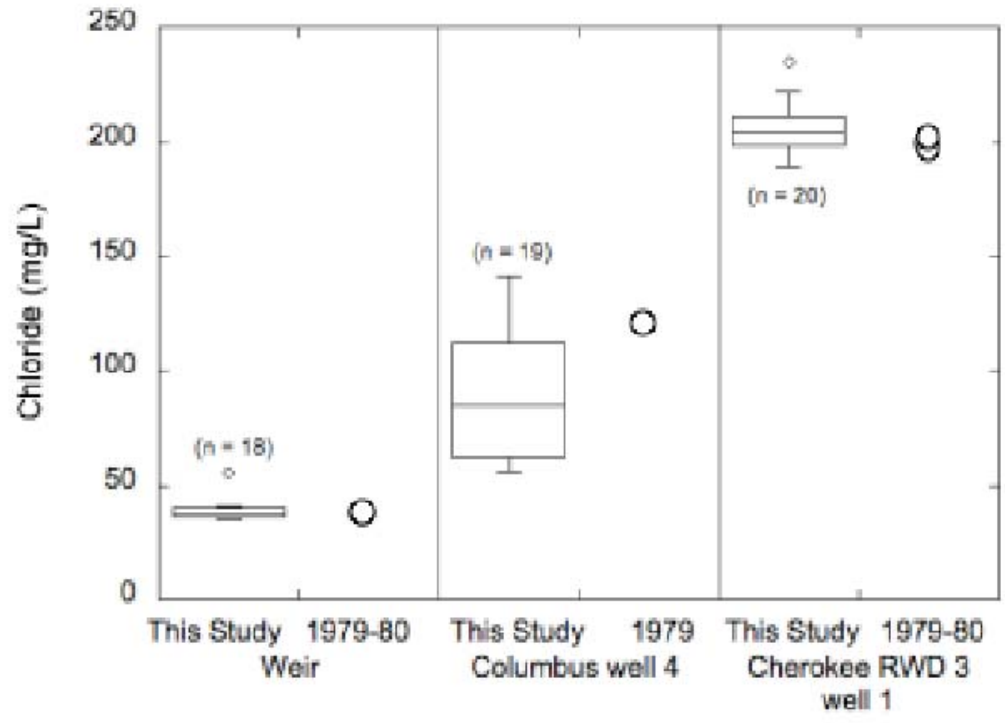

B.

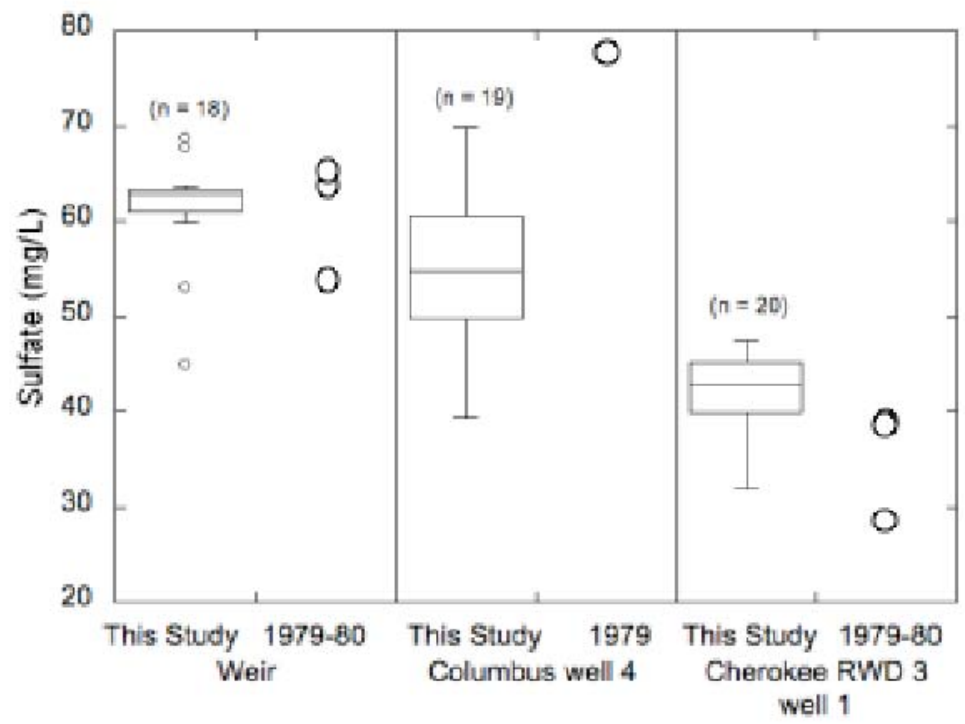

C.

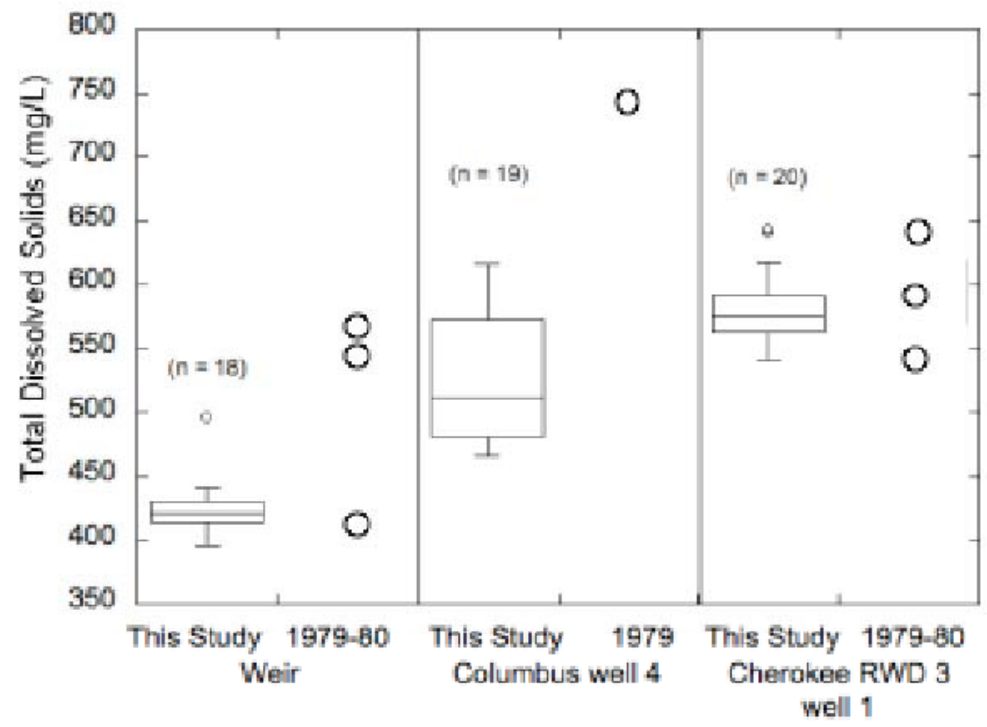

FIGURE 10-Box plot comparing the chloride, sulfate, and TDS concentrations of the 1979-1980 and 2006-08 water samples from wells in Cherokee County.

Current Research in Earth Sciences, Bulletin 258, part 3 (http://www.kgs.ku.edu/Current/2010/Macfarlane/index.html) 
June Test
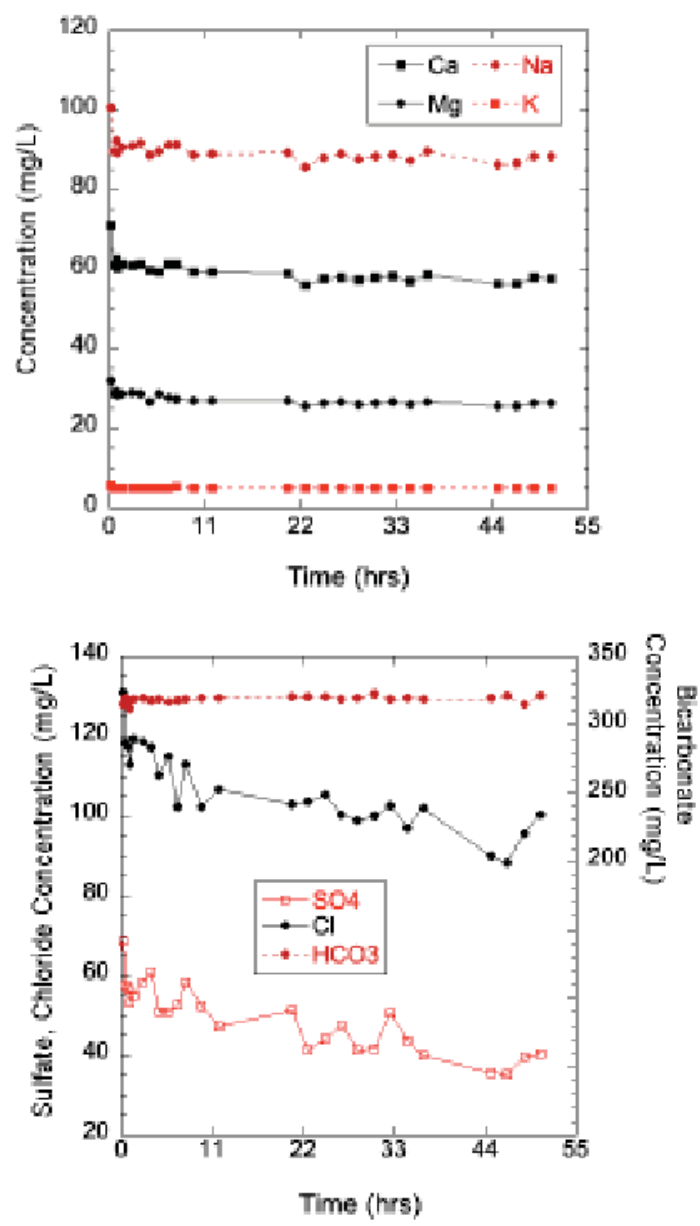

September Test
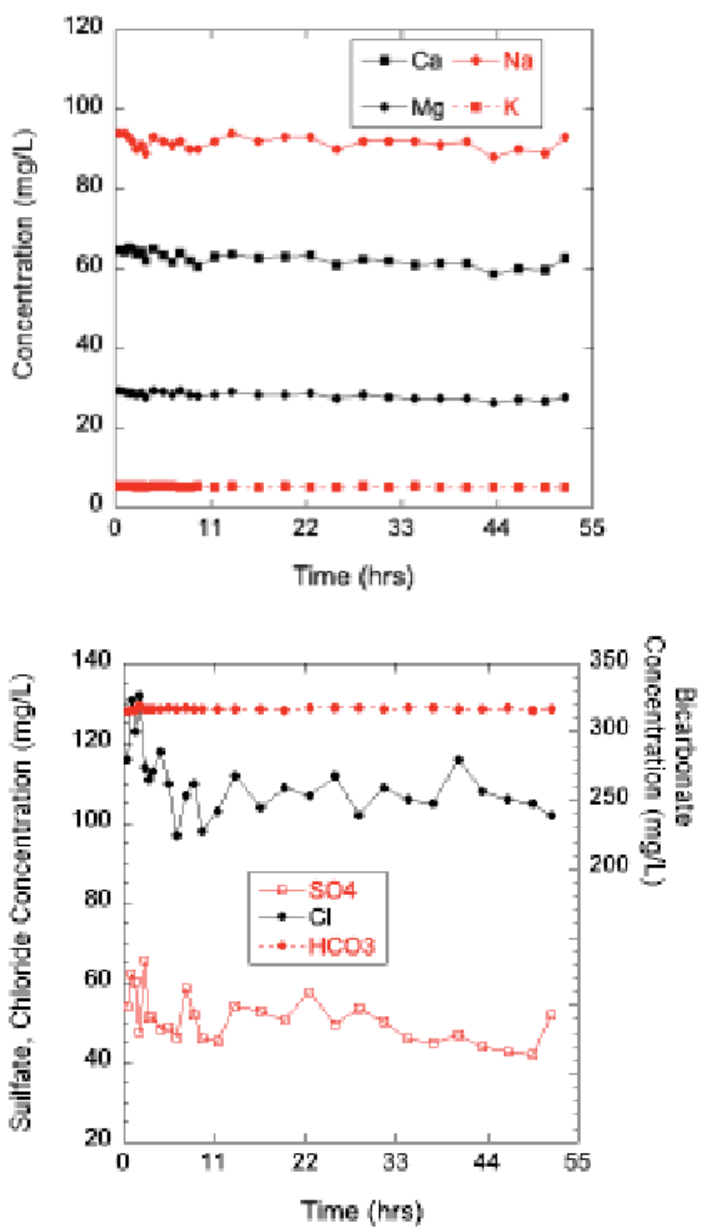

FIGURE 11-Temporal variations in the concentrations of selected major and minor constituents in water samples during the chemicalquality pumping tests of Pittsburg well 8 in June and September 2008.

was about 3 for remainder of the test (fig. 13). The TDS concentration decreased from $566 \mathrm{mg} / \mathrm{L}$ to $478 \mathrm{mg} / \mathrm{L}$ during the June test and from $543 \mathrm{mg} / \mathrm{L}$ to $484 \mathrm{mg} / \mathrm{L}$ during the September test.

The bicarbonate/(calcium + magnesium + strontium - sulfate) equivalent ratio is a measure of the amount of bicarbonate relative to that required to satisfy the calcium, magnesium, and strontium in the water that match up with carbonate mineral sources. The sulfate equivalent concentration is subtracted from the cation equivalent concentration to remove cation sources that match up with sulfate minerals. The (sodium + potassium)/chloride equivalent ratio is a measure of the amount of sodium + potassium relative to that required to satisfy the chloride equivalent concentration in the water. Because both ratios exceeded 1, they are defined as the excess bicarbonate and excess sodium + potassium ratios, respectively. In the June test, the lowest value of the excess bicarbonate ratio was near 1.1 in the very first sample but fluctuated between about 1.2 and 1.3 for the remainder of the pumping period, while the excess sodium + potassium ratio varied but trended upward from 1.2 to around 1.4 to 1.5 (figs. 14 and 15). In the September test, the excess bicarbonate ratio fluctuated appreciably during the first 4 hours and then stabilized around 1.2. The excess sodium + potassium ratio also varied substantially in the first four hours of the test and then increased and fluctuated around a value of approximately 1.4 (fig. 15). The low excess bicarbonate and sodium indicated by the ratios suggest that a significant amount of sodium-bicarbonate water was not contributed from the Springfield Plateau aquifer to the Ozark aquifer while Pittsburg well 8 was pumping.

\section{Mixing of Ground Waters from Differing Sources}

Overall, the produced waters from the wells monitored in this project are mixtures of ground waters 
TABLE 13-Chemical analyses of the monthly 2006-08 samples collected from the Weir city well.

\begin{tabular}{|c|c|c|c|c|c|c|c|c|c|c|c|}
\hline $\begin{array}{c}\text { Date } \\
\text { Sampled }\end{array}$ & $\begin{array}{l}\text { Sp. Con. } \\
(\mu \mathrm{S} / \mathrm{cm})\end{array}$ & pH & $\begin{array}{c}\text { TDS } \\
(\mathrm{mg} / \mathrm{L})\end{array}$ & $\begin{array}{c}\mathrm{Ca} \\
(\mathrm{mg} / \mathrm{L})\end{array}$ & $\begin{array}{c}\mathrm{Mg} \\
(\mathrm{mg} / \mathrm{L})\end{array}$ & $\begin{array}{c}\mathrm{Na} \\
(\mathrm{mg} / \mathrm{L})\end{array}$ & $\begin{array}{c}\mathrm{K} \\
(\mathrm{mg} / \mathrm{L})\end{array}$ & $\begin{array}{c}\mathrm{Sr} \\
(\mathrm{mg} / \mathrm{L})\end{array}$ & $\begin{array}{l}\mathrm{HCO}_{3} \\
(\mathrm{mg} / \mathrm{L})\end{array}$ & $\begin{array}{c}\mathrm{SO}_{4} \\
(\mathrm{mg} / \mathrm{L})\end{array}$ & $\begin{array}{c}\mathrm{Cl} \\
(\mathrm{mg} / \mathrm{L})\end{array}$ \\
\hline 4/13/06 & 707 & 7.54 & 423 & 62.1 & 29.7 & 47.8 & 5.69 & 1.04 & 325 & 61.3 & 35.0 \\
\hline $5 / 15 / 06$ & 732 & 7.49 & 430 & 58.7 & 28.1 & 55.3 & 5.6 & 1.02 & 339 & 63.3 & 40.2 \\
\hline 6/15/06 & 722 & 7.55 & 440 & 61.1 & 29.5 & 61.4 & 5.4 & 1.07 & 344 & 59.9 & 40.7 \\
\hline 7/13/06 & 745 & 7.41 & 442 & 58.9 & 28.6 & 62.6 & 6.5 & 1.04 & 350 & 60.0 & 40.7 \\
\hline 8/15/06 & 700 & 7.85 & 417 & 60.5 & 29.4 & 51.0 & 5.8 & 1.04 & 327 & 61.0 & 36.5 \\
\hline 9/19/06 & 767 & 7.80 & 427 & 59.4 & 28.8 & 54.2 & 4.5 & 1.04 & 337 & 62.9 & 39.5 \\
\hline 10/16/06 & 824 & 7.34 & 497 & 49.5 & 27.2 & 97.0 & 4.2 & 1.10 & 405 & 53.0 & 55.0 \\
\hline 11/21/06 & 707 & 7.45 & 421 & 61.8 & 30.8 & 46.1 & 4.9 & 1.02 & 325 & 67.8 & 37.4 \\
\hline $12 / 18 / 06$ & 726 & 7.65 & 432 & 59.6 & 29.9 & 56.6 & 5.1 & 1.03 & 339 & 62.2 & 39.0 \\
\hline $1 / 26 / 07$ & 720 & 7.50 & 414 & 62.8 & 29.1 & 46.5 & 5.5 & 1.04 & 323 & 62.9 & 35.9 \\
\hline 3/19/07 & 720 & 7.80 & 424 & 61.7 & 28.8 & 48.1 & 5.2 & 1.00 & 329 & 68.7 & 36.7 \\
\hline $4 / 1 / 07$ & 708 & 7.45 & 414 & 61.7 & 29.6 & 46.0 & 5.1 & 1.07 & 322 & 63.6 & 37.5 \\
\hline $5 / 14 / 07$ & 723 & 7.50 & 414 & 63.7 & 29.3 & 47.0 & 5.2 & 1.07 & 319 & 62.6 & 37.0 \\
\hline $6 / 1 / 07$ & 679 & 7.60 & 421 & 62.9 & 29.4 & 48.8 & 5.2 & 1.07 & 325 & 63.2 & 39.9 \\
\hline $8 / 1 / 07$ & 701 & 7.21 & 421 & 63.0 & 29.4 & 48.3 & 5.3 & 1.07 & 334 & 62.9 & 35.2 \\
\hline $10 / 1 / 07$ & 718 & 7.46 & 426 & 63.0 & 29.5 & 47.3 & 5.6 & 1.06 & 341 & 63.7 & 36.4 \\
\hline $12 / 1 / 07$ & 744 & 7.36 & 396 & 61.7 & 29.1 & 46.5 & 5.3 & 1.05 & 327 & 45.0 & 35.5 \\
\hline $1 / 25 / 08$ & 614 & 7.30 & 409 & 61.4 & 27.9 & 46.3 & 5.4 & 1.03 & 321 & 62.2 & 35.1 \\
\hline
\end{tabular}

TABLE 14—Chemical analyses of samples collected during the June 2008 chemical-quality pumping test for Pittsburg 8.

\begin{tabular}{|c|c|c|c|c|c|c|c|c|c|c|c|c|}
\hline Date/Time Sampled & $\begin{array}{c}\text { Sp. } \\
\text { Con. } \\
(\mu S / c m)\end{array}$ & $\begin{array}{c}\mathrm{T} \\
\left({ }^{\circ} \mathrm{C}\right)\end{array}$ & $\mathbf{p H}$ & $\begin{array}{c}\text { TDS } \\
\text { (mg/L) }\end{array}$ & $\underset{(\mathrm{mg} / \mathrm{L})}{\mathrm{Ca}}$ & $\begin{array}{c}\mathrm{Mg} \\
(\mathrm{mg} / \mathrm{L})\end{array}$ & $\begin{array}{c}\mathrm{Na} \\
(\mathrm{mg} / \mathrm{L})\end{array}$ & $\begin{array}{c}\mathrm{K} \\
(\mathrm{mg} / \mathrm{L})\end{array}$ & $\begin{array}{c}\mathrm{Sr} \\
(\mathrm{mg} / \mathrm{L})\end{array}$ & $\begin{array}{l}\mathrm{HCO}_{3} \\
\text { (mg/L) }\end{array}$ & $\begin{array}{c}\mathrm{SO}_{4} \\
(\mathrm{mg} / \mathrm{L})\end{array}$ & $\begin{array}{c}\mathrm{Cl} \\
(\mathrm{mg} / \mathrm{L})\end{array}$ \\
\hline 6/23/2008 11:01:00 & 968 & 22.5 & 6.89 & 566 & 70.9 & 32.1 & 100.8 & 5.8 & 1.10 & 315 & 68.8 & 131 \\
\hline 6/23/2008 11:16:00 & 938 & 22.1 & 6.99 & 519 & 60.9 & 28.6 & 89.7 & 4.9 & 0.97 & 320 & 57.6 & 119 \\
\hline 6/23/2008 11:31:00 & 935 & 22.1 & 6.93 & 521 & 62.7 & 29.2 & 92.2 & 5.1 & 1.00 & 318 & 56.6 & 118 \\
\hline 6/23/2008 11:46:00 & 931 & 22.1 & 6.99 & 505 & 60.5 & 28.3 & 89.4 & 5.0 & 0.97 & 312 & 53.4 & 113 \\
\hline 6/23/2008 12:14:00 & 922 & 22.4 & 6.97 & 519 & 61.2 & 28.8 & 90.7 & 5.0 & 0.98 & 319 & 55.1 & 119 \\
\hline 6/23/2008 13:21:00 & 917 & 23.0 & 6.95 & 522 & 61.1 & 28.9 & 91.0 & 5.1 & 0.99 & 320 & 58.3 & 118 \\
\hline 6/23/2008 14:21:00 & 919 & 22.8 & 6.94 & 523 & 61.2 & 28.8 & 91.7 & 5.1 & 1.00 & 318 & 60.9 & 117 \\
\hline 6/23/2008 15:21:00 & 914 & 22.8 & 6.96 & 500 & 59.6 & 26.6 & 88.8 & 5.0 & 0.95 & 319 & 50.9 & 110 \\
\hline 6/23/2008 16:29:00 & 906 & 22.8 & 7.04 & 506 & 59.4 & 28.6 & 89.8 & 4.9 & 0.98 & 317 & 50.9 & 115 \\
\hline 6/23/2008 17:29:00 & 902 & 22.8 & 7.05 & 499 & 61.5 & 27.8 & 91.3 & 5.0 & 0.98 & 318 & 52.8 & 103 \\
\hline 6/23/2008 18:29:00 & 894 & 22.6 & 7.10 & 515 & 61.4 & 27.4 & 91.4 & 5.2 & 0.99 & 319 & 58.5 & 113 \\
\hline 6/23/2008 20:29:00 & 896 & 22.2 & 7.00 & 494 & 59.4 & 27.0 & 88.8 & 5.1 & 0.96 & 320 & 52.3 & 103 \\
\hline 6/23/2008 22:29:00 & 888 & 21.7 & 7.01 & 493 & 59.3 & 26.9 & 88.9 & 5.1 & 0.97 & 320 & 47.2 & 107 \\
\hline 6/24/2008 7:19:00 & 878 & 20.7 & 7.02 & 494 & 59.0 & 27.0 & 89.5 & 5.1 & 0.97 & 321 & 51.4 & 103 \\
\hline 6/24/2008 9:19:00 & 874 & 21.4 & 6.99 & 477 & 56.1 & 25.8 & 85.6 & 4.9 & 0.92 & 321 & 41.5 & 104 \\
\hline 6/24/2008 11:19:00 & 873 & 22.1 & 7.07 & 486 & 57.8 & 26.4 & 88.0 & 5.0 & 0.95 & 321 & 43.9 & 105 \\
\hline 6/24/2008 13:19:00 & 876 & 22.6 & 7.05 & 485 & 58.1 & 26.6 & 88.9 & 5.0 & 0.96 & 319 & 47.7 & 100 \\
\hline 6/24/2008 15:19:00 & 876 & 22.2 & 6.89 & 475 & 57.3 & 26.1 & 87.7 & 4.9 & 0.95 & 320 & 41.5 & 99 \\
\hline 6/24/2008 17:19:00 & 872 & 22.3 & 6.99 & 450 & 58.0 & 26.4 & 88.3 & 5.0 & 0.96 & 323 & 41.6 & 99.9 \\
\hline 6/24/2008 19:19:00 & 871 & 21.9 & 6.93 & 490 & 58.3 & 26.6 & 88.8 & 5.1 & 0.97 & 319 & 50.6 & 103 \\
\hline 6/24/2008 21:19:00 & 869 & 21.8 & 6.99 & 475 & 57.1 & 26.0 & 87.3 & 5.0 & 0.95 & 320 & 43.8 & 97.1 \\
\hline 6/24/2008 23:19:00 & 863 & 21.8 & 6.97 & 480 & 58.7 & 26.6 & 89.6 & 5.1 & 0.98 & 319 & 39.9 & 102 \\
\hline 6/25/2008 7:28:00 & 866 & 21.1 & 6.95 & 458 & 56.2 & 25.8 & 86.3 & 5.0 & 0.93 & 320 & 35.6 & 89.9 \\
\hline 6/25/2008 9:28:00 & 865 & 21.5 & 6.94 & 457 & 56.5 & 25.8 & 86.8 & 5.0 & 0.94 & 322 & 35.3 & 88.2 \\
\hline 6/25/2008 11:28:00 & 865 & 22.3 & 6.96 & 470 & 58.1 & 26.3 & 88.5 & 5.1 & 0.96 & 315 & 39.8 & 95.6 \\
\hline 6/25/2008 13:28:00 & 871 & 22.4 & 7.04 & 478 & 57.6 & 26.3 & 88.4 & 5.0 & 0.96 & 322 & 40.2 & 101 \\
\hline
\end{tabular}


TABLE 15-Chemical analyses of samples collected during the September 2008 chemical-quality pumping test for Pittsburg 8.

\begin{tabular}{|c|c|c|c|c|c|c|c|c|c|c|c|c|}
\hline $\begin{array}{c}\text { Date/Time } \\
\text { Sampled }\end{array}$ & $\begin{array}{l}\text { Sp. Con. } \\
(\mu S / c m)\end{array}$ & $\begin{array}{c}\mathrm{T} \\
\left({ }^{\circ} \mathrm{C}\right)\end{array}$ & pH & $\begin{array}{c}\text { TDS } \\
\text { (mg/L) }\end{array}$ & $\underset{(\mathrm{mg} / \mathrm{L})}{\mathrm{Ca}}$ & $\begin{array}{c}\mathrm{Mg} \\
(\mathrm{mg} / \mathrm{L})\end{array}$ & $\begin{array}{c}\mathrm{Na} \\
(\mathrm{mg} / \mathrm{L})\end{array}$ & $\begin{array}{c}\mathrm{K} \\
(\mathrm{mg} / \mathrm{L})\end{array}$ & $\begin{array}{c}\mathrm{Sr} \\
(\mathrm{mg} / \mathrm{L})\end{array}$ & $\begin{array}{l}\mathrm{HCO}_{3} \\
\text { (mg/L) }\end{array}$ & $\begin{array}{c}\mathrm{SO}_{4} \\
(\mathrm{mg} / \mathrm{L})\end{array}$ & $\begin{array}{c}\mathrm{Cl} \\
(\mathrm{mg} / \mathrm{L})\end{array}$ \\
\hline 9/2/2008 9:40:00 & 975 & 22.0 & 7.2 & 520 & 64.7 & 29.2 & 94.0 & 5.3 & 1.04 & 315 & 53.9 & 116 \\
\hline 9/2/2008 10:10:00 & 974 & 21.9 & 7.11 & 543 & 64.4 & 29.1 & 94.0 & 5.2 & 1.04 & 316 & 62.2 & 131 \\
\hline 9/2/2008 10:40:00 & 972 & 22.0 & 7.32 & 533 & 65.5 & 28.6 & 93.0 & 5.3 & 1.01 & 316 & 60.4 & 123 \\
\hline 9/2/2008 11:10:00 & 969 & 22.8 & 7.26 & 529 & 65.0 & 28.7 & 92.0 & 5.2 & 1.00 & 320 & 47.6 & 132 \\
\hline 9/2/2008 11:40:00 & 970 & 23.3 & 7.17 & 524 & 63.6 & 28.5 & 90.0 & 5.1 & 0.98 & 317 & 65.7 & 114 \\
\hline 9/2/2008 12:10:00 & 968 & 23.8 & 7.11 & 509 & 64.3 & 28.8 & 91.0 & 5.2 & 0.99 & 317 & 51.3 & 111 \\
\hline 9/2/2008 12:40:00 & 928 & 23.6 & 7.09 & 505 & 62.0 & 27.7 & 89.0 & 5.0 & 0.96 & 317 & 51.2 & 113 \\
\hline 9/2/2008 13:40:00 & 933 & 23.4 & 7.15 & 517 & 65.0 & 29.5 & 93.0 & 5.2 & 1.01 & 317 & 48.5 & 118 \\
\hline 9/2/2008 14:40:00 & 961 & 23.5 & 7.17 & 507 & 63.5 & 29.0 & 92.0 & 5.2 & 0.99 & 318 & 49.0 & 110 \\
\hline 9/2/2008 15:40:00 & 931 & 23.3 & 7.02 & 487 & 61.7 & 28.4 & 91.0 & 5.3 & 0.94 & 317 & 46.3 & 97 \\
\hline 9/2/2008 16:40:00 & 956 & 23.3 & 7.11 & 514 & 64.0 & 29.2 & 92.0 & 5.1 & 1.01 & 318 & 58.6 & 107 \\
\hline 9/2/2008 17:40:00 & 953 & 23.0 & 7.15 & 505 & 61.9 & 28.5 & 90.0 & 5.0 & 0.98 & 317 & 51.9 & 110 \\
\hline 9/2/2008 18:40:00 & 950 & 22.4 & 7.18 & 485 & 60.6 & 28.1 & 90.0 & 5.3 & 0.92 & 317 & 46.0 & 98 \\
\hline 9/2/2008 20:40:00 & 927 & 21.3 & 7.13 & 494 & 63.0 & 28.5 & 92.0 & 5.1 & 1.00 & 317 & 45.3 & 103 \\
\hline 9/2/2008 22:40:00 & 945 & 21.3 & 7.14 & 516 & 63.8 & 28.9 & 94.0 & 5.2 & 1.02 & 317 & 54.3 & 112 \\
\hline 9/3/2008 1:40:00 & 937 & & 7.18 & 503 & 62.7 & 28.5 & 92.0 & 5.1 & 1.00 & 317 & 52.9 & 104 \\
\hline 9/3/2008 4:40:00 & 928 & & 7.24 & 506 & 63.1 & 28.3 & 93.0 & 5.2 & 1.01 & 316 & 50.8 & 109 \\
\hline 9/3/2008 7:40:00 & 916 & 19.4 & 7.21 & 513 & 63.3 & 28.7 & 93.0 & 5.1 & 1.02 & 318 & 57.6 & 107 \\
\hline 9/3/2008 10:40:00 & 926 & 20.6 & 7.27 & 503 & 61.1 & 27.5 & 90.0 & 5.0 & 0.99 & 318 & 49.6 & 112 \\
\hline 9/3/2008 13:40:00 & 928 & 20.6 & 7.28 & 501 & 62.3 & 28.4 & 92.0 & 5.3 & 1.00 & 318 & 53.6 & 102 \\
\hline 9/3/2008 16:40:00 & 918 & 20.3 & 7.27 & 503 & 61.9 & 27.6 & 92.0 & 5.1 & 1.00 & 317 & 50.3 & 109 \\
\hline 9/3/2008 19:40:00 & 919 & 20.2 & 7.30 & 496 & 60.9 & 27.5 & 92.0 & 5.4 & 0.99 & 318 & 46.1 & 106 \\
\hline 9/3/2008 22:40:00 & 913 & 20.1 & 7.29 & 493 & 61.3 & 27.2 & 91.0 & 5.1 & 0.99 & 318 & 45.1 & 105 \\
\hline 9/4/2008 1:40:00 & 910 & & 7.33 & 506 & 61.5 & 27.5 & 92.0 & 5.1 & 1.00 & 317 & 46.9 & 116 \\
\hline 9/4/2008 4:40:00 & 913 & & 7.34 & 487 & 58.8 & 26.2 & 88.0 & 4.9 & 0.95 & 317 & 44.0 & 108 \\
\hline 9/4/2008 7:40:00 & 908 & 20.3 & 7.34 & 489 & 60.0 & 27.0 & 90.0 & 5.0 & 0.98 & 318 & 42.6 & 106 \\
\hline 9/4/2008 10:40:00 & 910 & 20.1 & 7.28 & 484 & 59.6 & 26.8 & 89.0 & 5.0 & 0.97 & 316 & 42.0 & 105 \\
\hline 9/4/2008 12:57:00 & 907 & 21.6 & 7.32 & 500 & 62.6 & 27.8 & 93.9 & 5.1 & 1.02 & 317 & 52.1 & 102 \\
\hline
\end{tabular}

from 1) sodium-chloride brine and calcium, magnesiumbicarbonate freshwater sources in the Ozark aquifer (fig. 1); 2) the Ozark and Springfield Plateau aquifers in multiaquifer wells; and 3) zones within the Ozark aquifer, each with its own ground-water chemistry (Macfarlane and Hathaway, 1987). Downward leakage from the overlying Springfield Plateau aquifer, though probably minor, may also mix with Ozark aquifer ground water in areas where the confining layer is fractured, thin, or absent. The relative amount contributed by each of these sources depends on well location within the transition zone, well construction, intensity and duration of pumping, and thickness and degree of fracturing of the confining layer separating the Ozark from the Springfield Plateau aquifer where it has not been eroded.

Produced water type generally becomes increasingly more sodium and chloride rich with increasing distance down the hydraulic gradient from the eastern, fresh- transition zone boundary (fig. 1). This relationship is most clearly illustrated in the plots of chloride versus the bicarbonate/chloride ratio and chloride versus the (sodium + potassium)/chloride ratio for the wells sampled in this project (figs. 16 and 17). Both plots show two outer mixing lines that bound regions where points plot for published and unpublished analyses of Ozark aquifer water samples collected in 1979-1980 from the Tri-state region (Macfarlane and Hathaway, 1987). Points for saline waters (with chloride concentration $>500 \mathrm{mg} / \mathrm{L}$ ) collected in 1980 from downgradient wells in the Ozark Plateau aquifer in Crawford and Cherokee counties and from lowchloride upgradient wells in southwestern Missouri are also plotted in figs. 16 and 17. The dashed line in fig. 16 represents a mixing curve fitted to the water-chemistry data from the upgradient and downgradient end members. This mixing curve plots within the region defined by the two bounding curves, and with the exception of Cherokee 

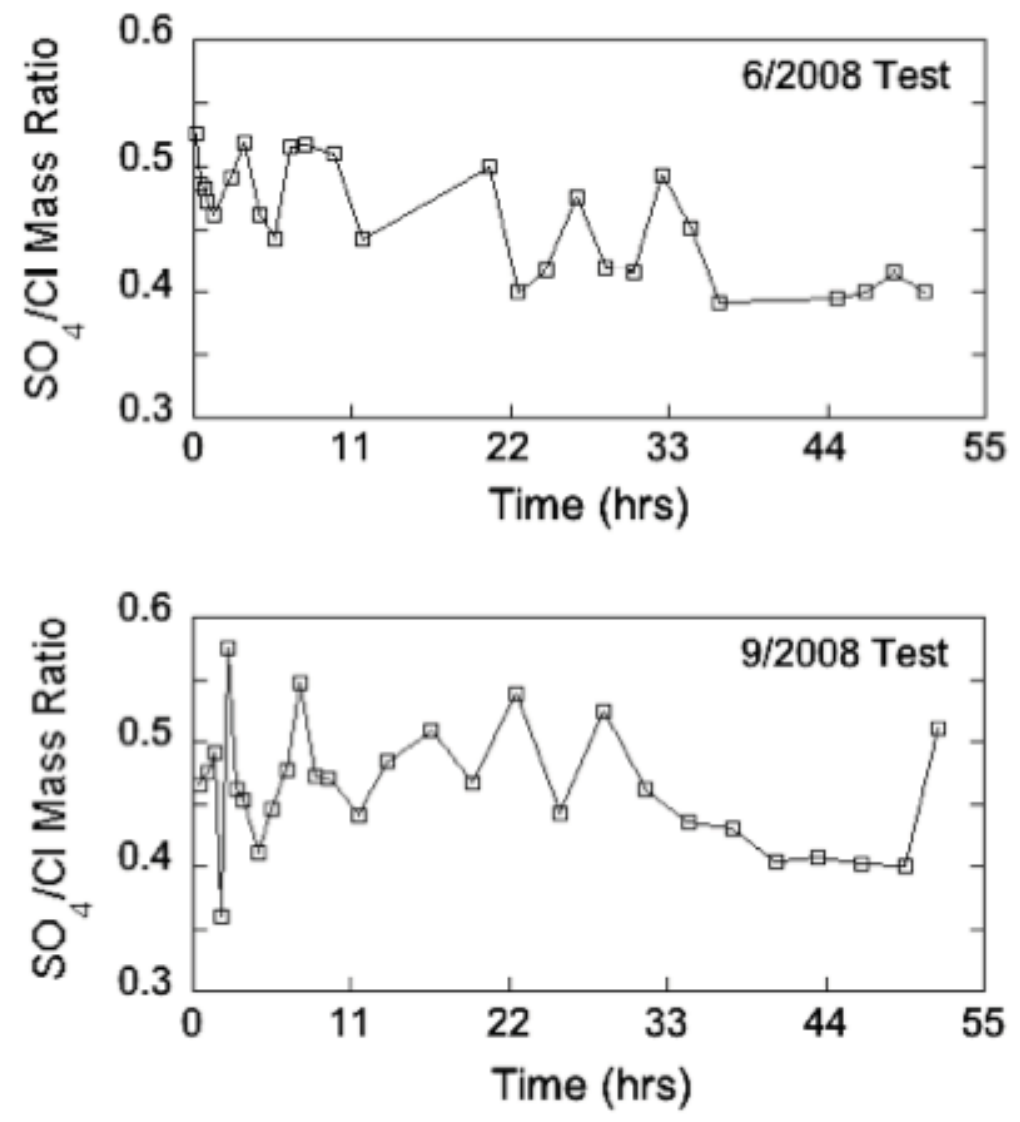

FIGURE 12 (left)—Temporal variations in the $\mathrm{SO}_{4} /$ $\mathrm{Cl}$ mass ratio in water samples during the chemical-quality pumping tests of Pittsburg well 8 in June and September 2008.

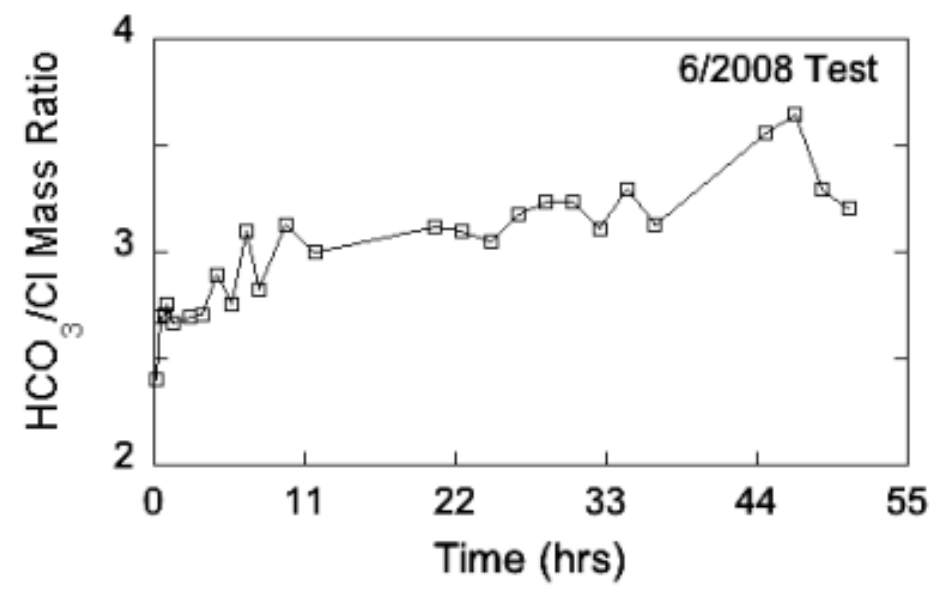

FIGURE 13 (right)-Temporal variations in the $\mathrm{HCO}_{3} /$ $\mathrm{Cl}$ mass ratio in water samples during the chemicalquality pumping tests of Pittsburg well 8 in June and September 2008.

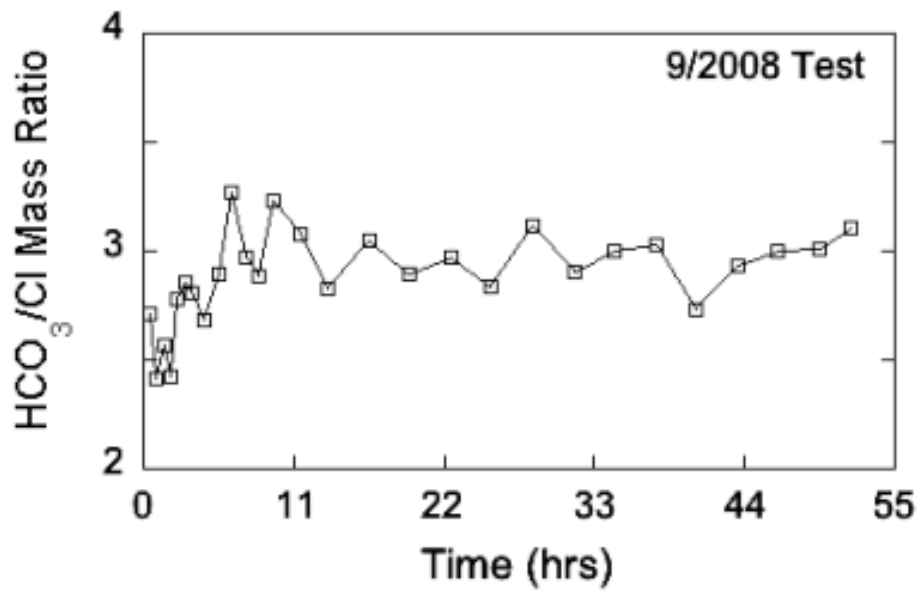



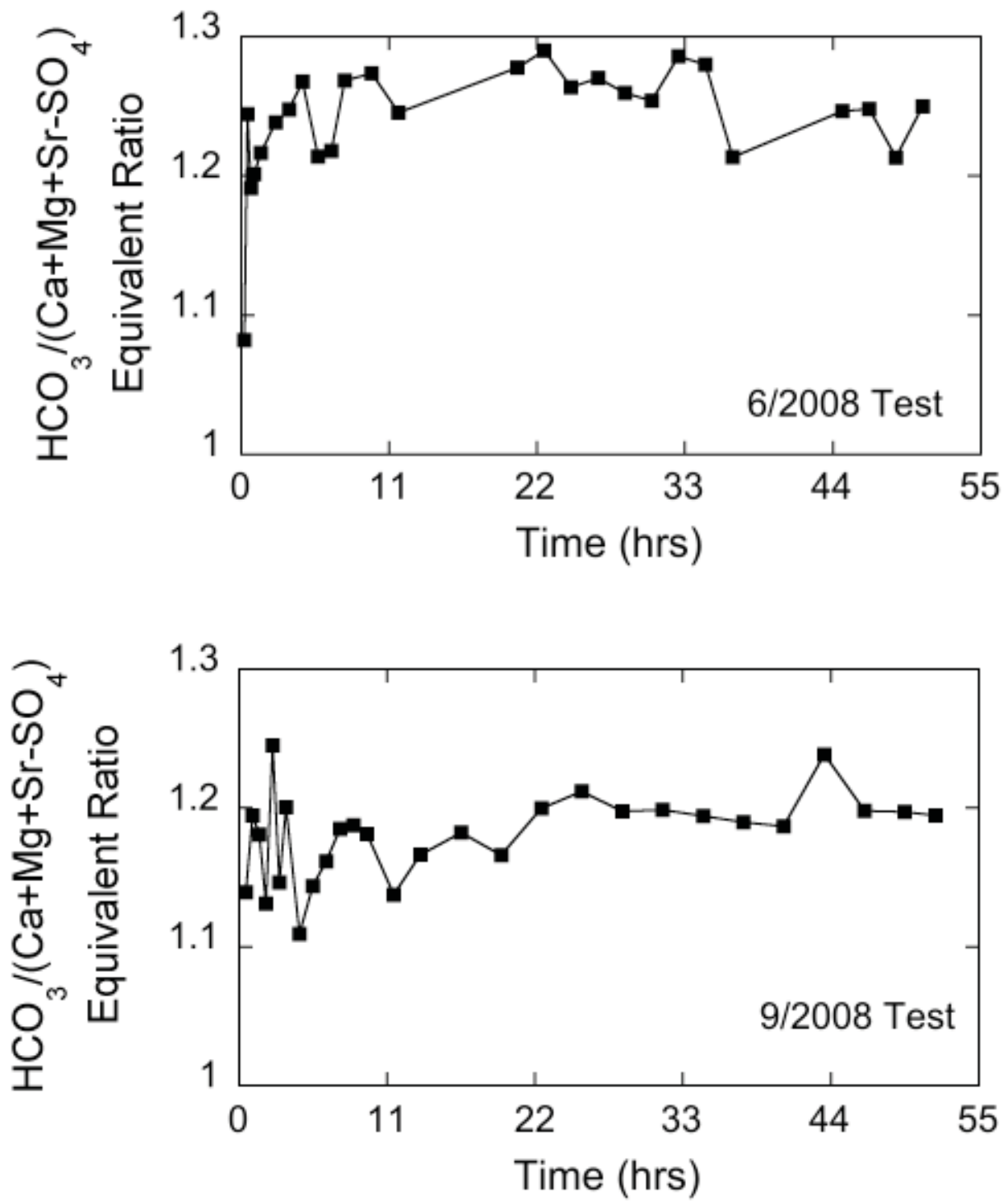

FIGURE 14-Temporal variations in the bicarbonate/(calcium + magnesium + strontium - sulfate ratio) in water samples during the chemical-quality pumping tests of Pittsburg well 8 in June and September 2008.

RWD 3 well 1, points for all the Ozark well samples fall along it. A decrease in the bicarbonate to chloride ratio with an increase in the chloride concentration from the Crawford RWD 4 well 3 and Pittsburg well 10 to Girard well 3 and Crawford Consolidated Rural Water District 1 well 2 demonstrates a progressive westward change in water type across southeastern Crawford County. The data from multi-aquifer wells plot very close to or directly on the dashed mixing curve line, which suggests that the relative contribution of water from the Springfield Plateau aquifer to these wells is minor. In fig. 17, the (sodium + potassium)/chloride equivalent ratio approaches 1 as the chloride concentration increases to $200 \mathrm{mg} / \mathrm{L}$. However, for reasons discussed later in this section, many of the monthly data sets do not plot parallel to the bounding mixing curves for the 1979-1980 data.

Addition of the historic data from the 1979-1980 period to the chloride versus bicarbonate/ratio plot of fig. 16 provides a means of evaluating changes in water chemistry over time in the context of the mixing of water within the Ozark aquifer transition zone (fig. 18). Differences among the sets of data collected from this project and the historic data indicate that the most significant changes in Ozark aquifer chemistry occurred in the waters produced from Pittsburg 10 and Crawford Consolidated RWD 1 well 2, with little if any change in the water pumped by Cherokee RWD 3 well 1 (fig. 18). For the Crawford RWD 5 well 1 multi-aquifer well, a slight shift in the monthly data toward higher chloride relative to the historic data suggests only a minor change in water quality with respect to chloride and bicarbonate. The quality of the produced water from the other multi-aquifer wells does not appear to have changed significantly between the two sampling periods.

Within the transition zone, the sulfate/chloride ratio generally decreases with increasing chloride 

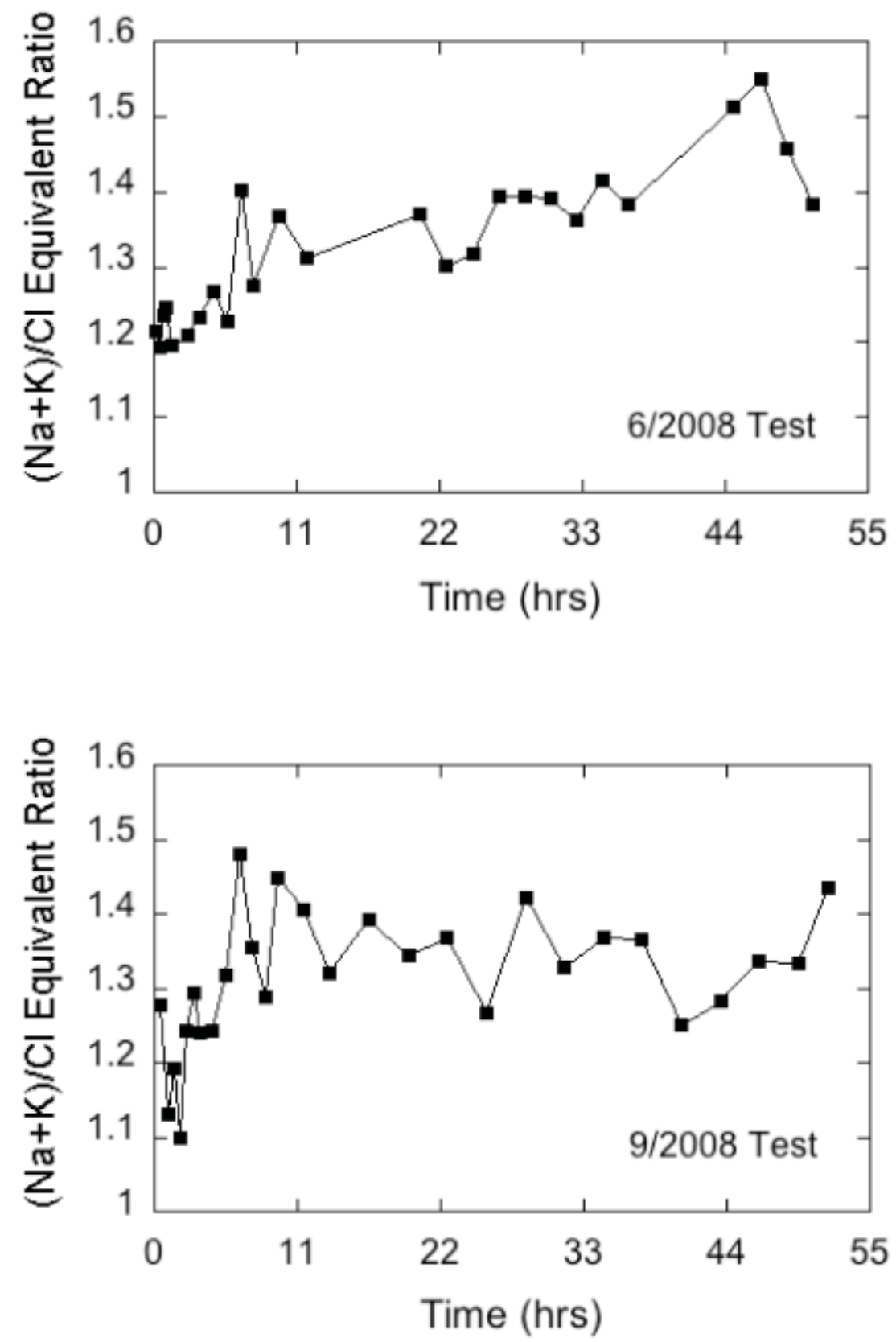

FIGURE 15-Temporal variations in the (sodium + potassium)/chloride ratio in water samples during the chemical-quality pumping tests of Pittsburg well 8 in June and September 2008.

concentration (fig. 19) as mixing with sodium-chloride type water increases down the hydraulic gradient towards the Cherokee basin brines. In addition, the sulfate concentration generally decreases as hydrogen sulfide concentration increases (Macfarlane and Hathaway, 1987). This relationship is thought to reflect a lateral change within the Ozark aquifer toward more chemically reducing conditions. Although, in aggregate, the monthly sample data generally follow a pattern of decreasing sulfate/ chloride ratio with increasing chloride concentration, only the Weir city well and Columbus well 4 monthly data had a substantial change in chloride concentration that followed the overall trend of points in fig. 19.
Data from the water-quality pumping tests also suggest that zones of differing water quality within the aquifer contribute water to a pumping well at different rates throughout a single pumping period. It is also possible that the quality of water produced by individual zones may change without a change in the relative amount contributed to the well during pumping. Figure 20 is a plot of the bicarbonate/chloride ratio versus chloride concentration for the samples from both pumping tests plotted with the same mixing curve as the dashed line on fig. 16. The plot shows an excellent fit between the data and the chloridebicarbonate mixing curve. The trend of the plotted pumping test chloride and the (sodium + potassium)/chloride ratio 


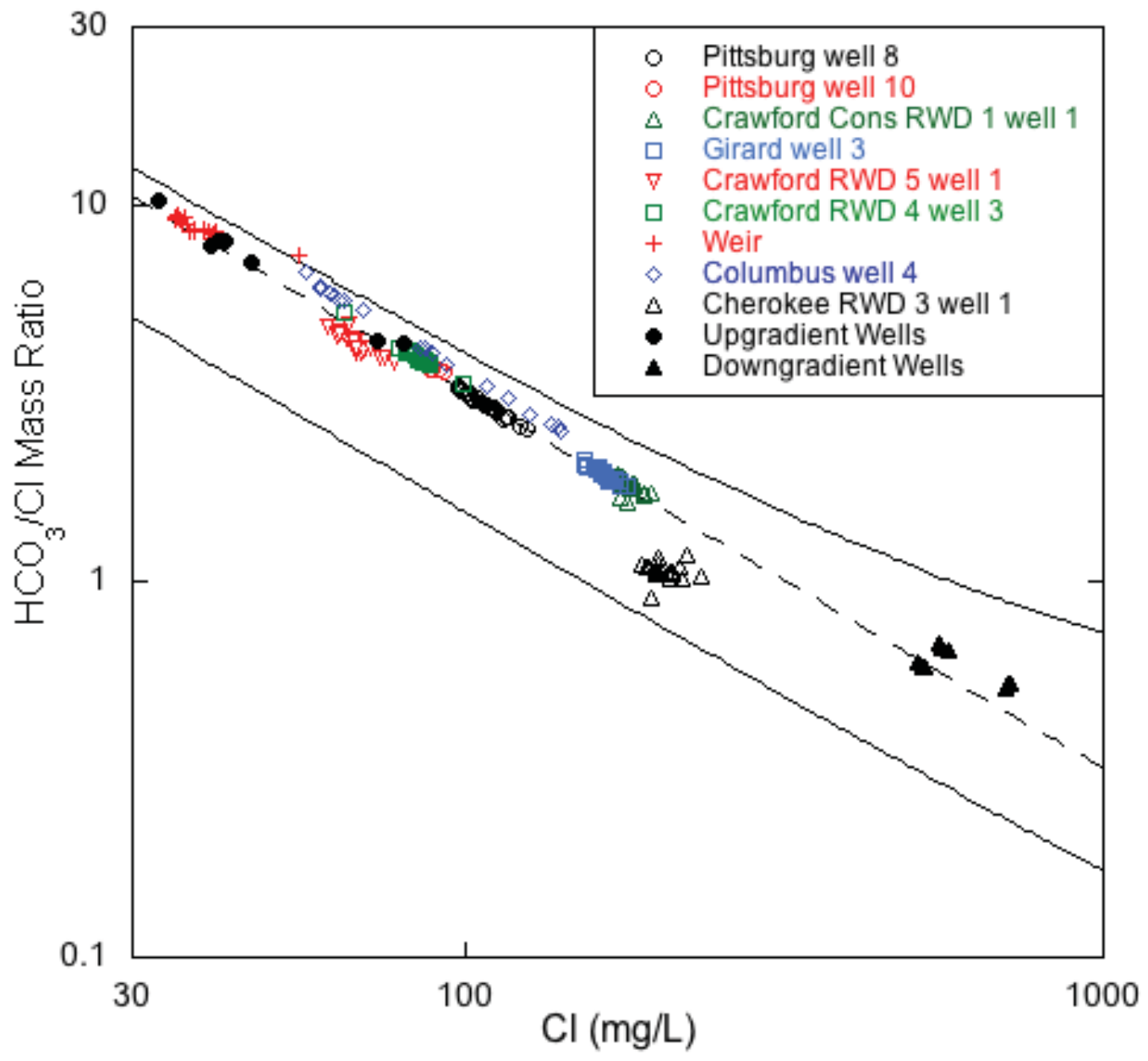

FIGURE 16-Chloride concentration versus bicarbonate/chloride ratio for the monthly samples of 2006-08 and for samples from upgradient and downgradient wells sampled in 1979-1980 from Crawford and Cherokee counties and adjacent southwestern Missouri. The solid lines are curves that describe the mixing curves that bound where points would plot for the 1979-1980 sample data for the Tri-state region and the dashed line is a mixing curve based on a low-chloride end member for the freshest waters from the 2006-08 monthly data and a high-chloride end member for the middle of the group of the saline waters. The curves describe the mixing of various proportions of waters from the low TDS concentration, calcium, magnesium-bicarbonate province and the high TDS, sodium-chloride sources.

values follows well the trend of the monthly data for Pittsburg 8 and many of the other supplies sampled, but not as well as the overall trend of the data from the 19791980 samplings (fig. 21). The ranges of the bicarbonate to chloride and sodium + potassium to chloride ratios and the chloride concentration values are greater for the samples from the pumping tests than for the Pittsburg well 8 monthly samples. The differences in trend between the regional 1979-1980 data sets and the monthly data and the high degree of variability of the sodium + potassium/ chloride ratios over the pumping period are both consistent with time varying amounts of these constituents being contributed to the open borehole from different zones each with its own water chemistry.

Springfield Plateau aquifer wells located above the Ozark aquifer transition zone in southeast Kansas and southwest Missouri produce sodium-bicarbonate type water (Darr, 1978; Macfarlane and Hathaway, 1987). Macfarlane and Hathaway (1987) noted that water samples from some of the multi-aquifer wells within the bounds of the Ozark aquifer transition zone contained bicarbonate in excess of that required to satisfy the equivalent carbonate contribution of calcium, magnesium, and strontium in the sample. The excess bicarbonate ratio is about the same for both the Ozark and multi-aquifer wells, but the excess sodium + potassium ratios are generally higher for the multi-aquifer wells. Excess sodium + potassium values range from about 1.5 to almost 3 in samples from the multiaquifer wells and 1 to about 1.5 for samples from the Ozark wells. The lower values for the Ozark well samples suggest that leakage across the confining unit is at most minor. 


\begin{tabular}{|llll|}
\hline$\circ$ & Pittsburg well 8 & + & Weir \\
$\circ$ & Pittsburg well 10 & $\diamond$ & Columbus well 4 \\
$\Delta$ & Crawford Cons. RWD 1 well 2 & $\bullet$ & Cherokee RWD 3 well 1 \\
$\square$ & Girard well 3 & $\bullet$ & Upgradient wells \\
$\nabla$ & Crawford RWD 5 well 1 & $\bullet$ & Downgradient Wells \\
$\square$ & Crawford RWD 4 well 3 & & \\
\hline
\end{tabular}

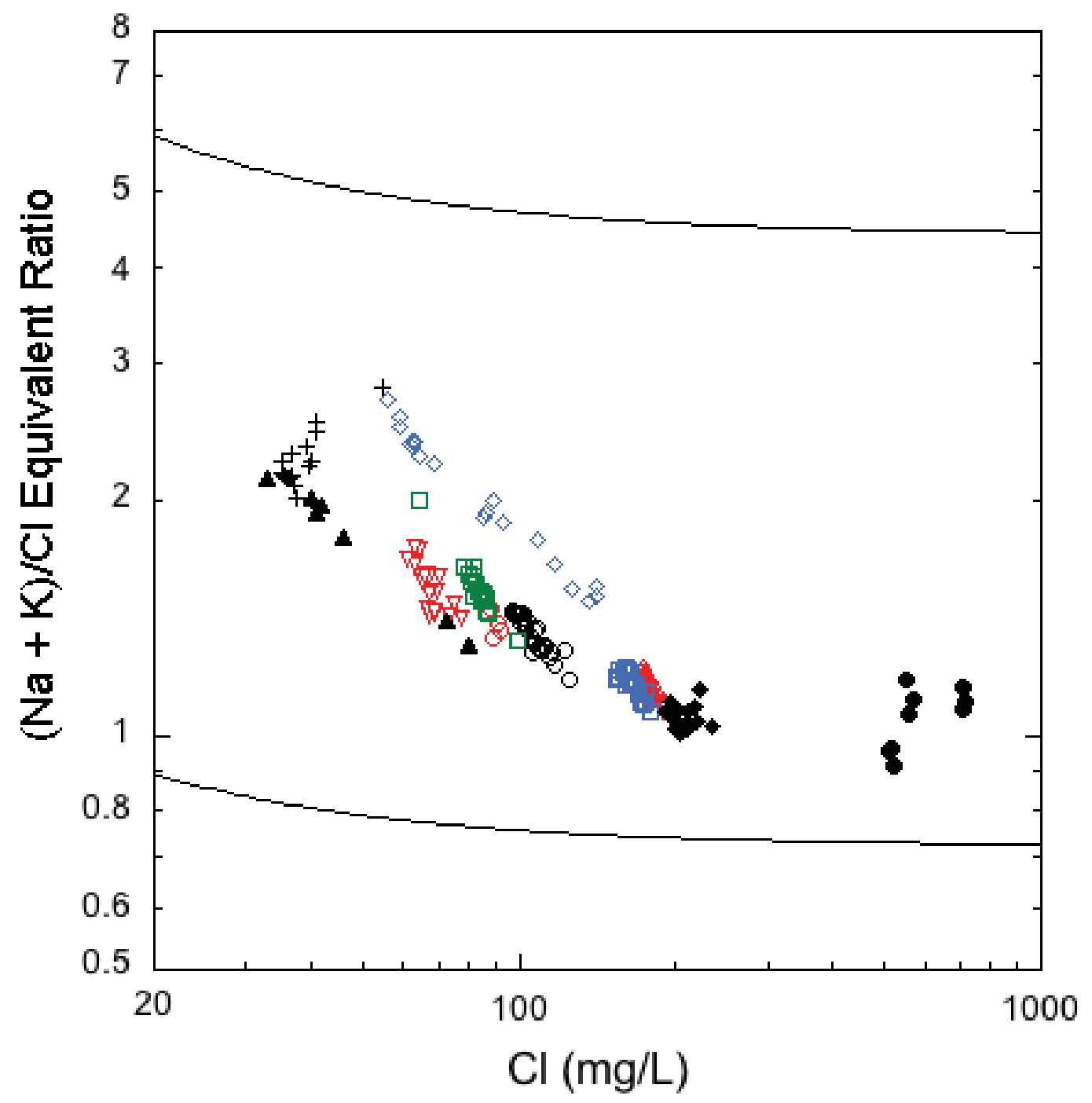

FIGURE 17-Chloride concentration versus sodium/chloride ratio values for the monthly samples of 2006-08 and for samples from upgradient and downgradient wells sampled in 1979-1980 from Crawford and Cherokee counties and adjacent southwestern Missouri. The solid lines are curves that describe the mixing curves that bound where points would plot for the 1979-1980 sample data for the Tri-State region. The curves describe the mixing in various proportions of waters from the low TDS concentration, calcium, magnesium-bicarbonate province and the high TDS, sodium-chloride province.

\section{Discussion}

The vertical variation in water quality in any well within the transition zone ultimately depends on the amount of mixing that has occurred over long periods between the inflowing low TDS freshwater from recharge areas in southwest Missouri and the resident sodium-chloride brines to the west in the Cherokee basin (Macfarlane and Hathaway, 1987). The plots in figs. 11-15 for the Pittsburg well 8 pumping tests imply that waters of differing quality are contributed from different parts of the aquifer at different rates to the well during pumping. Changes in the 


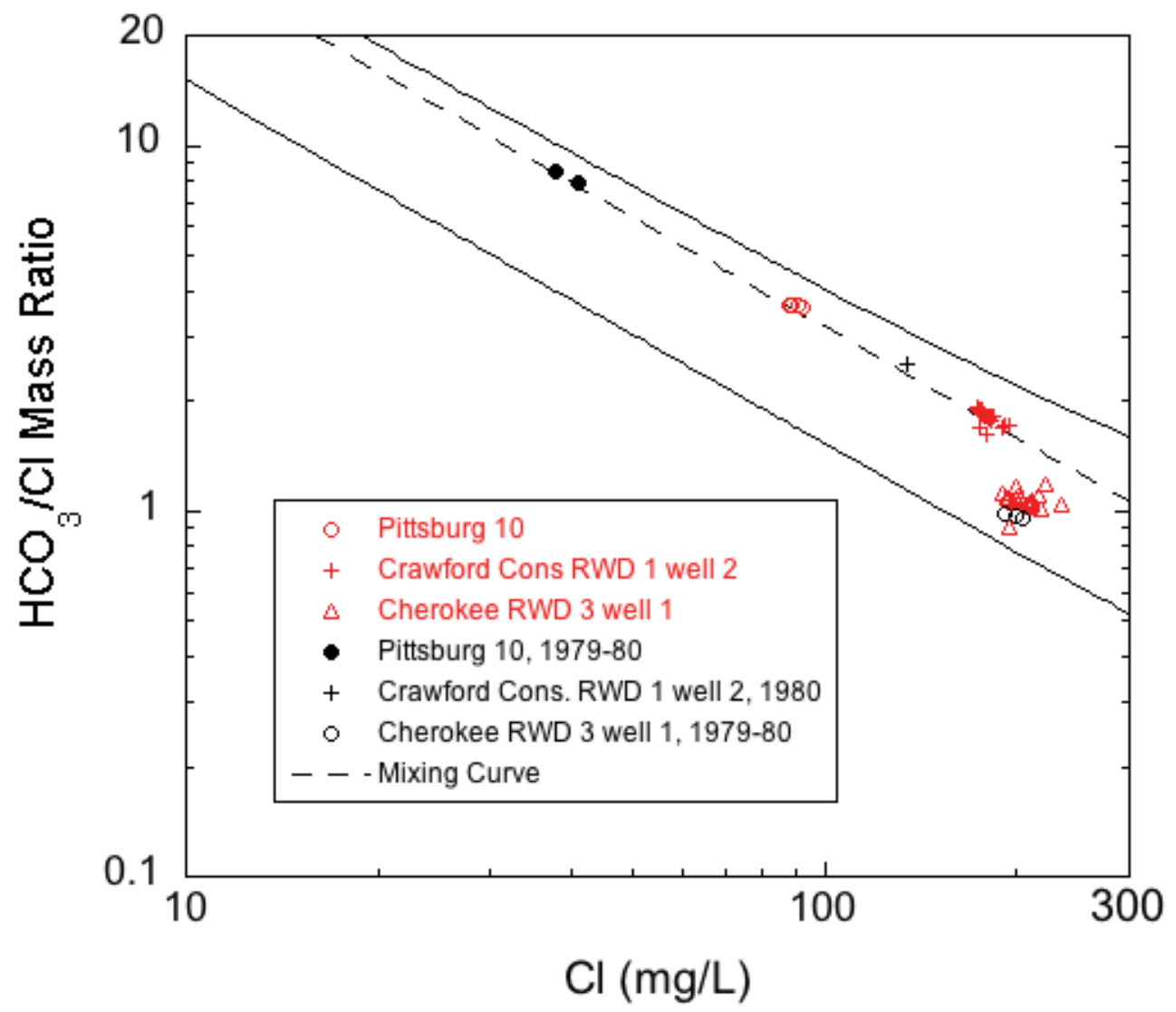

FIGURE 18-Comparison of the 1979-1980 and 2006-08 chloride and bicarbonate/chloride ratios in samples from Pittsburg well 10, Crawford Consolidated RWD 1 well 2, and Crawford RWD 5 well 1.

constituent concentrations as pumping progressed during the tests indicate that the amounts contributed from each source within the aquifer change with time. In particular, the excellent fit of the data points from both tests with the mixing curve on a bicarbonate to chloride ratio versus chloride plot clearly indicates changes in the mixing of water from fresh and more saline end-members within the open borehole of the well.

This interpretation is supported by U.S. Geological Survey data from August 2007 flowmeter measurements and sampling of produced water collected at various depths within the open borehole section from the Pittsburg well 10 after it had been pumped for one week (figs. 1, 22A1, 22A2; Pope et al., 2009). The depth and construction of well 8 are nearly identical to those of well 10, which is located approximately 1,400 $\mathrm{ft}$ (427 m) to the south. The pump in well 10 is situated in the cased portion of the borehole, $350 \mathrm{ft}$ (107 m) below the well top. A well-bore flowmeter survey of Pittsburg well 10 revealed that $77 \%$ of the flow into the open borehole was contributed by two thin zones from $837 \mathrm{ft}$ to $857 \mathrm{ft}$ ( $255 \mathrm{~m}$ to $261 \mathrm{~m}$ ) in the lower part of the Roubidoux Formation (Zone 2) and from $977 \mathrm{ft}$ to $997 \mathrm{ft}$ (298 $\mathrm{m}$ to $304 \mathrm{~m}$ ) in the middle of the Gasconade Dolomite (Zone 3; fig. 22A1). More of the total flow came from Zone 2 (about 46\%) than Zone 3 (about 31\%). Because of the close proximity, similar construction, and depth of the wells, it is reasonable to conclude that the open borehole section of well 8 also penetrates Zones 1 through 4. Chloride concentration and the bicarbonate to chloride ratio for six water samples collected within the borehole from 487 to $1,030 \mathrm{ft}$ below the top of well 10 after a week of pumping ranged from $54 \mathrm{mg} / \mathrm{L}$ to $110 \mathrm{mg} / \mathrm{L}$ and 2.73 to 5.37, respectively (fig. 22A2).

The chloride concentration entering from each of the four zones in the open borehole of well 10 was estimated using a rearranged form of equation 1 , the flowmeter data (fig. 22A1), and chloride concentrations of water sampled from various levels within the well (fig. 22A2). In the calculation, it is assumed that the flow entering the open borehole from each of the zones moves upward toward the pump and mixes with water below the zone. Equation 1 can be expressed as

$$
\mathrm{C}_{1} f_{1}+\mathrm{C}_{2} f_{2}=\mathrm{C}_{3}\left(f_{1}+f_{2}\right)
$$

where $f_{1}$ is the fractional amount of water in relation to the total at the top of the zone with a chloride concentration of $\mathrm{C}_{1}$ that is moving upward from below the zone in question, 

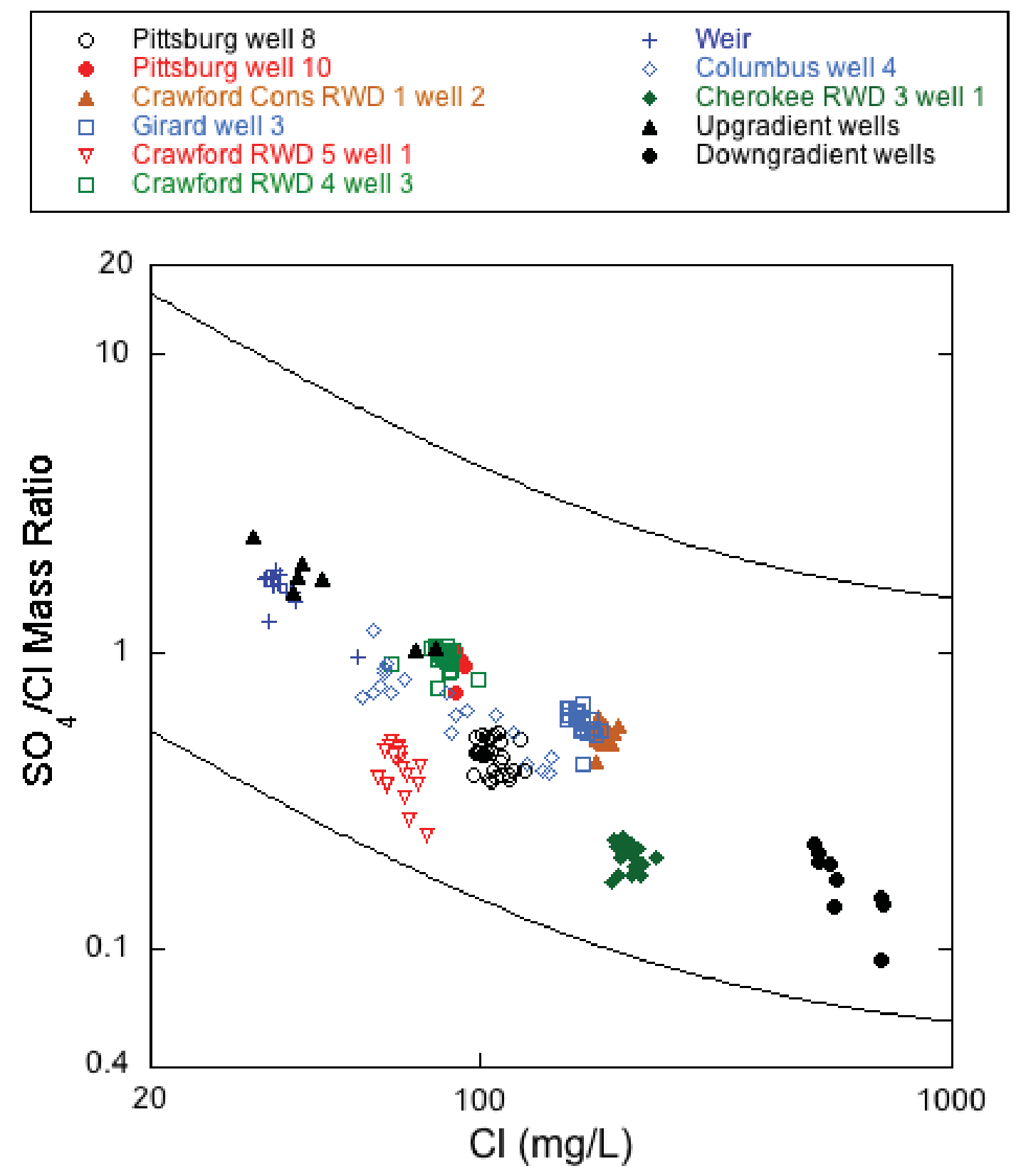

FIGURE 19—Chloride concentration versus sulfate/chloride ratio for the monthly samples of 2006-08 and for samples from upgradient and downgradient wells sampled in 1979-1980 from Crawford and Cherokee counties and adjacent southwestern Missouri. The solid lines are curves that describe the mixing curves that bound where points would plot for the 1979-1980 sample data for the Tri-state region. The curves describe the mixing of various proportions of water of low TDS concentration and calcium, magnesium-bicarbonate type with water of low to moderate sulfate and high TDS concentration and sodium-chloride type with very low sulfate.

$f_{2}$ is the fractional amount of water in relation to the total at the top of the zone with a chloride concentration of $\mathrm{C}_{2}$ that is moving into the well from the zone, and $\mathrm{C}_{3}$ is the concentration of the mix at the top of the zone. With two end-member mixing, $f_{1}+f_{2}$ are equal to 1 and

$$
f_{2}=1-f_{1} \text {. }
$$

Substitution of equation 3 into equation 2 and solving for $\mathrm{C}_{2}$ produces

$$
\mathrm{C}_{2}=\left(\mathrm{C}_{3}-\mathrm{C}_{1} f_{1}\right) /\left(1-f_{1}\right) \text {. }
$$

The profile in fig. 22A3 combines the calculated chloride concentrations of water entering the well in each zone with the chloride concentrations of the samples collected between the zones. The calculation was performed starting at the top of zone 3 and moving upward. The plot shows that the chloride concentration does not change monotonically with depth from zone to zone but rather decreases from $77 \mathrm{mg} / \mathrm{L}$ to $60 \mathrm{mg} / \mathrm{L}$ from Zone 1 to Zone 2, 


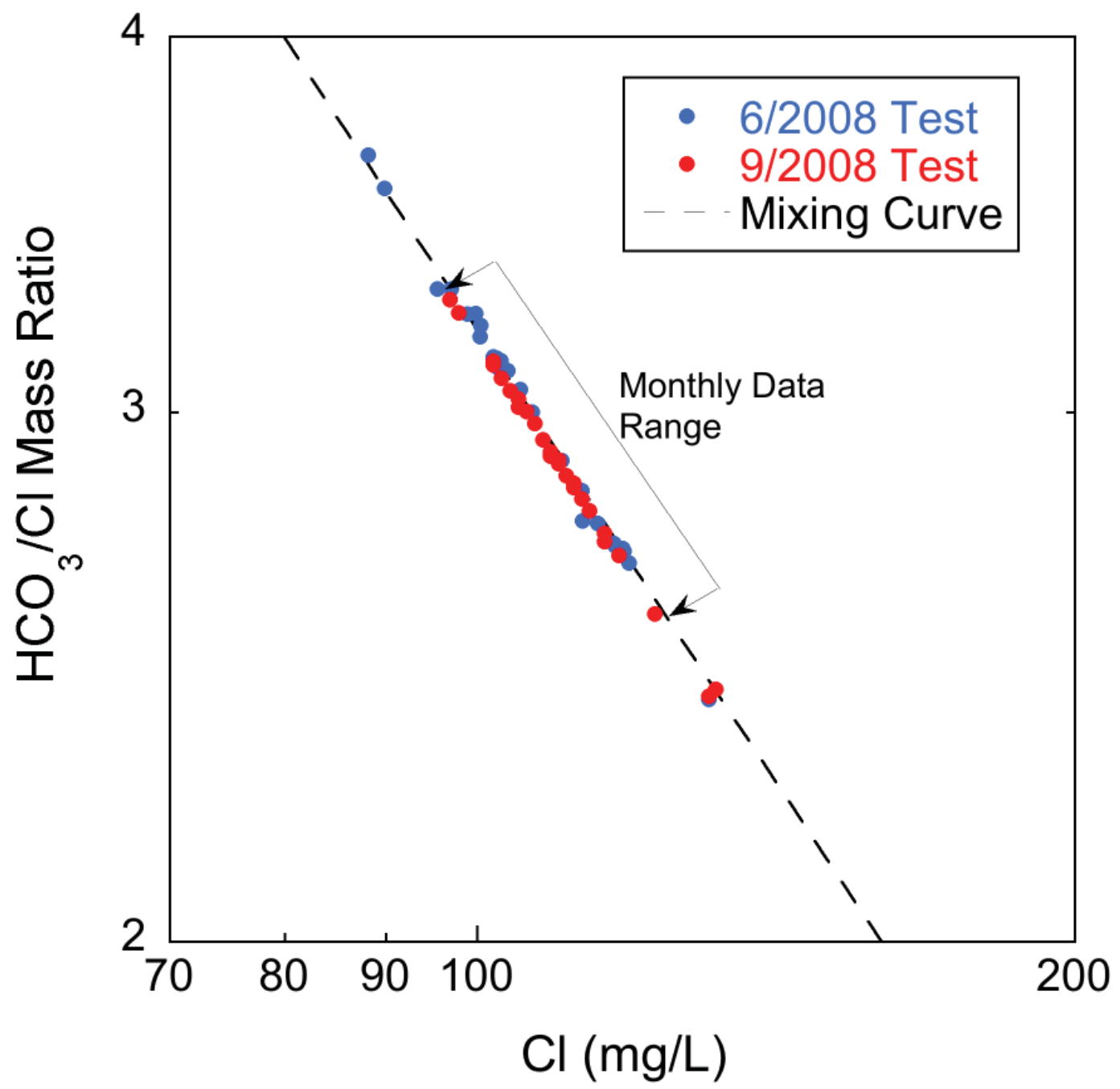

FIGURE 20-Chloride concentration versus bicarbonate/chloride ratio for the samples from the June and September 2008 water-quality pumping tests of Pittsburg well 8. The dashed line is the same mixing curve as on fig. 16 that fits the monthly datasets for the nine project wells.

increases from $60 \mathrm{mg} / \mathrm{L}$ to $122 \mathrm{mg} / \mathrm{L}$ from Zone 2 to Zone 3, and decreases from $122 \mathrm{mg} / \mathrm{L}$ to $54 \mathrm{mg} / \mathrm{L}$ from Zone 3 to Zone 4 . These changes occur over a vertical interval of about $300 \mathrm{ft}(91 \mathrm{~m})$ in the upper part of the Ozark aquifer. The lowest chloride concentration and highest bicarbonate to chloride ratio occurred in water collected near the bottom of the well, indicating that saline water is not entering the deepest zone of the well at the well location. However, it is important to note that for the most productive zones, Zone 2 produced lower chloride water than Zone 3.

The well-head sample collected after a week of pumping Pittsburg well 10 plots close to the mixing curve in fig. 22B and follows the trend of decreasing chloride concentration and increasing bicarbonate to chloride ratio with increasing length of the pumping period established in the June and September 2008 pumping tests of Pittsburg well 8 (figs. 11 and 13). The close overlap of the range of data for Pittsburg wells 8 and 10 shown on fig. 22B suggests that the temporal changes in the chloride concentration and bicarbonate to chloride ratio observed in both well 8 tests could have resulted from changes in the relative volumes of water contributed to the well by different zones over time. Changes in the quality of water produced from different depth zones over time, as well as a combination of both processes could also be explanations. It is unclear which of these scenarios accounts for the general decrease in the chloride concentration of the water produced at the wellhead (fig. 11). The substantially different water quality and flow rate for different depth zones in the aquifer suggest that some of the variability in the chloride and bicarbonate concentrations occurring during both pumping tests could have resulted from small variations in the pumping rate. 


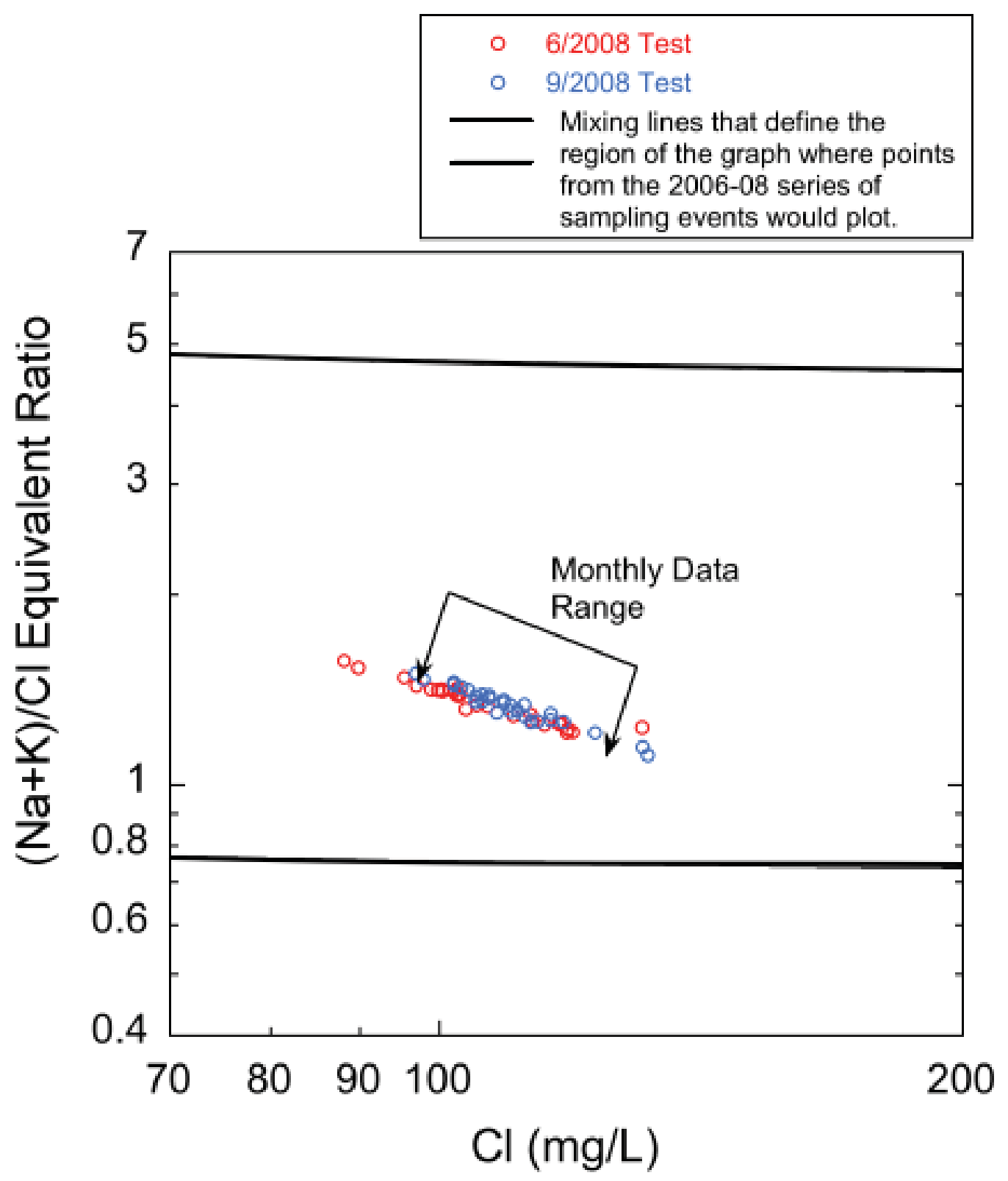

FIGURE 21-Chloride concentration versus sodium + potassium/chloride ratio values for the samples from the June and September pumping tests for Pittsburg well 8. The solid lines are mixing curves that bound the region where the points would plot for the data from the 1979-1980 sampling events.

After a week of pumping well 10, more of the flow entering the open borehole came from Roubidoux Formation sandstones in Zone 2 than from the equally thick Zone 3 in the dolostones of the Gasconade dolomite (fig. 22A1). This difference in flow rates suggests that the transmissivity of Zone 2 is higher than that of Zone 3. Most of the flow from Zone 3 is from secondary permeability features within the Gasconade Dolomite. Data are not available from well 10 to assess the degree of vertical fracturing or carbonate rock dissolution in this interval of the well. However, the Pittsburg well field is located near the crest of the Pittsburg anticline (fig. 3) and fracture sets developed on and parallel to the crest of the structure would be extensional in origin, presumably with wider apertures than sets developed on the flanks or in the adjacent synclines. The higher chloride concentration in water discharging from Zone 3 suggests that these more open fractures could tap sources of higher chloride water that could exist in the lower part of the Ozark and St. Francois aquifers. However, vertical profiles of hydraulic head in the open borehole section of well 10 were not collected prior to and following pumping to lend support for this hypothesis. 
A

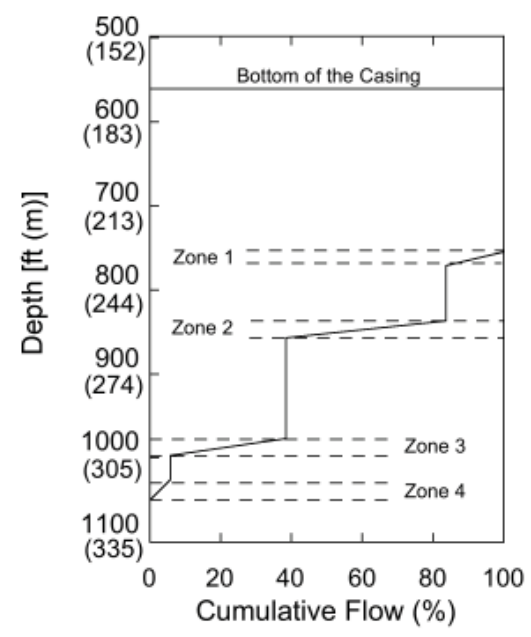

1

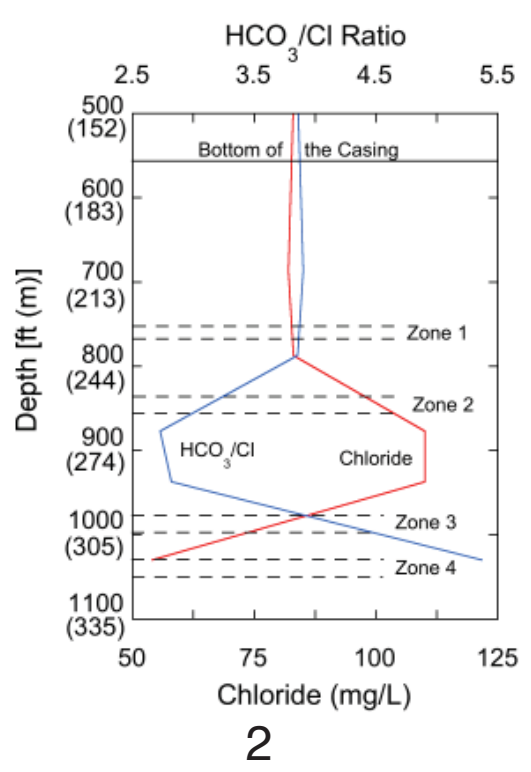

5.5

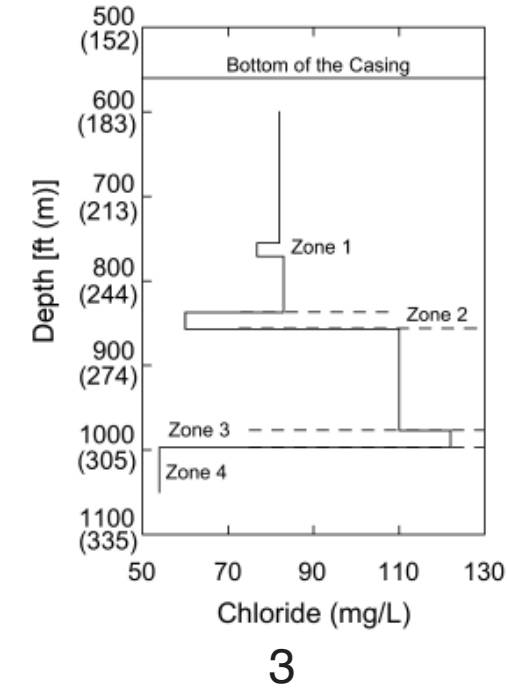

B

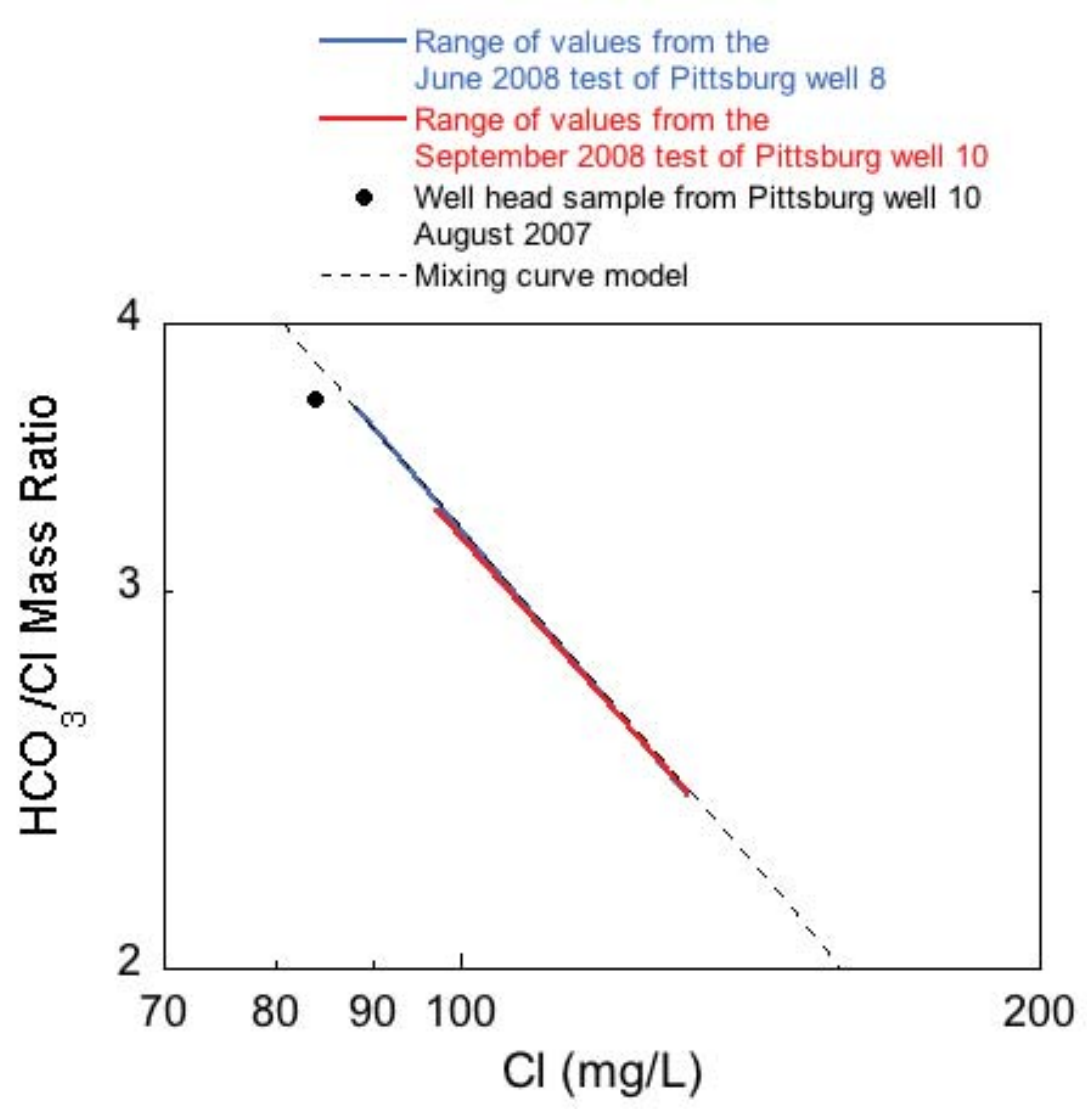

FIGURE 22- (A) Cumulative flow (A1), chloride concentration and bicarbonate to chloride ratio (A2), and calculated zonal chloride concentration (A3) versus depth in Pittsburg well 10; and (B) chloride concentration and bicarbonate to chloride ratio range for samples from the June and September 2008 pumping tests of Pittsburg well 8 in comparison to the wellhead sample collected from Pittsburg well 10. All samples were collected after one week of continuous pumping. Pittsburg well 10 data are from Pope et al. (2009).

Drawdown from individual pumping events could induce 1) lateral flow of lower chloride water through the Roubidoux Formation sandstones from the shallow part of the aquifer and 2) upward flow of higher chloride water from deeper transmissive intervals within the Gasconade
Dolomite into the well and the adjacent sandstones. The June test was conducted prior to the annual period of high pumping stress, and hydraulic head in the aquifer was higher in the well field (fig. 5) and presumably in both Zones 2 and 3. Prior to this test, the hydraulic head in Zone 
3 could have been higher than in Zone 2, which would have allowed higher chloride water to move into this upper zone. When the pump for well 8 was turned on, water from all of the zones would start to flow into the well. In the early part of the pumping period, the higher chloride water from Zone 3 and the part of Zone 2 affected by Zone 3 water would have entered the well resulting in the observed higher chloride concentration (fig. 11). Continued pumping would have gradually flushed the higher chloride water from Zone 2, resulting in a gradual decline in the chloride concentration with time. Turning off the well could potentially have allowed water from deeper zones to continue to flow slowly upwards into the well from Zone 3 into Zone 2 during recovery. Prior to the September well 8 pumping test, higher pumping stress lowered the hydraulic head in the Ozark aquifer in the Pittsburg area generally as indicated by the lower water levels in the monitoring well (fig. 5). This could have increased the vertical hydraulic head gradients within the Ozark aquifer and consequently, the potential for upward flow from deeper flow zones during pumping. The early drawdown in the September well 8 test could have initially induced more flow into the well from Zone 2 than from Zone 3 causing the chloride in the produced water in the early part of the pumping period to decrease (fig. 11). As pumping progressed, the flow from Zone 2 could have slowed sufficiently relative to Zone 3 because of further increases in the vertical hydraulic head gradient so that the continued decline in the chloride concentration of the produced water over time would have eventually ceased (fig. 11). Alternatively, vertical head gradients could have induced leakage of water from Zone 3 to Zone 2 within the aquifer resulting in a decreasing rate of decline in the chloride concentration.

Long-term change in the quality of produced water is occurring very slowly and over many cycles of pumping and recovery and high and low stress periods at Pittsburg well 10 and Crawford Consolidated RWD 1 well 2 as indicated by the datasets from this project, the 19791980 sampling events, and from Darr (1978). Because of the limited sampling that was done in 1979-1980, the amount of change in the bicarbonate and chloride concentrations over the last 25 years is difficult to gauge (fig. 18). However, if the variability in the monthly data from Pittsburg well 8 is similar to that of Pittsburg 10, the apparent change in produced water quality from Pittsburg well 10 from 1979-1980 to 2006-08 is much greater than the monthly variability (fig. 16). The chloride concentration versus bicarbonate/chloride mixing plot in fig. 16 shows that the long-term change in quality of the produced water from Pittsburg well 8 follows the mixing curve from lower chloride to higher chloride values. Assuming that the water quality in Pittsburg well 10 has evolved over time in a manner similar to that of Pittsburg well 8, then the general decrease in chloride concentration and an increase in the bicarbonate/chloride ratio during both pumping tests appears opposite to the long-term trend. Higher levels of pumping during certain times of the year cause a general lowering of the hydraulic head within the Ozark aquifer and the Pittsburg area wells to produce higher chloride water after extended pumping such as indicated by fig. 18.

Upward migration of saline water from the lower part of the Ozark and St. Francois aquifers is a much simpler explanation of the increased salinity in the Pittsburg area wells than eastward migration of more saline water into the area. The observed decrease in the chloride concentration with extended pumping in the well 8 pumping tests is difficult to explain if it is assumed that saline water is moving into the area from the west. In that scenario, the chloride concentration in the produced water during a single pumping period should be relatively constant or possibly increase with time. However, data are currently lacking to evaluate the potential for upward movement of more saline water into the upper part of the Ozark aquifer from deeper zones.

Macfarlane and Hathaway (1987) and Imes and Emmett (1994) speculated that downward leakage from the Springfield Plateau aquifer was a major source of recharge to the Ozark aquifer in the Tri-state region. This is not evident in the results of the Pittsburg 8 chemicalquality pumping tests (figs. 14-15). Ground waters from the Springfield Plateau aquifer in southeast Kansas are a sodium-bicarbonate type (Macfarlane and Hathaway, 1987). A Springfield Plateau aquifer well located $1 \mathrm{mi}$ $(1.3 \mathrm{~km})$ northeast of Pittsburg 8 was sampled twice in 1979-1980. The average excess sodium + potassium and bicarbonate ratios from the two samplings are 15.3 and 21.7 , respectively. In the June pumping test, the excess sodium + potassium ratio rose to approximately 1.5 with some fluctuation throughout the pumping period. In the September test, the ratio rose early and then remained relatively constant at approximately 1.35 throughout the remainder of the pumping period. In both tests, the excess bicarbonate ratio remained relatively constant with values below 1.25 . The low excess bicarbonate and sodium + potassium ratios from the June and September tests suggest that pumping-induced recharge from leakage is either negligible or, if small, is masked by cation exchange and carbonate equilibria that alter the water chemistry.

The chloride concentration for the three monthly samples collected from Pittsburg well 10 during 2006 to 2007 ranged from 88.9 to $109 \mathrm{mg} / \mathrm{L}$. The chloride concentration range for three samples obtained from the same well during 1979-1980 was 38-41 mg/L. If the minimum and maximum differences in chloride concentration between the two sampling periods are divided by the time between the periods, the rate of chloride increase ranges from 1.8 to $2.6 \mathrm{mg} / \mathrm{L} / \mathrm{yr}$. The minimum and maximum chloride concentrations observed for the two pumping tests of Pittsburg well 8 during 2008 were 88.2 and $132 \mathrm{mg} / \mathrm{L}$, respectively. If the chloride content of Pittsburg well 8 during 1979-1980 was about the same as for Pittsburg well 10 (around $40 \mathrm{mg} / \mathrm{L}$ ), then the 
rate of chloride increase for Pittsburg well 8 ranges from 1.7 to $3.2 \mathrm{mg} / \mathrm{L} / \mathrm{yr}$. Based on the value and the date of the maximum chloride concentration observed for each of the two wells and the maximum rate of chloride increase, and assuming that the increase rate remains linear with time, the chloride level would not exceed the recommended drinking water limit of $250 \mathrm{mg} / \mathrm{L}$ until approximately 37 years (the year 2045) for Pittsburg well 8 and 54 years (the year 2060) for Pittsburg well 10.

The range in increase rate estimates indicate that the data from the monthly sampling and pumping tests of Pittsburg well 8 have important ramifications for designing a water-quality monitoring protocol to determine long-term changes in water quality. For this well, the greater ranges of chloride concentration for the pumping test samples than for the monthly samples underscores the need to factor short-term variability in produced water chemistry into the frequency of sampling, the timing of sampling relative to pump start-up and possibly to seasonal water use, and the analysis of the resulting data for trend. The monthly sampling results for many of the other wells sampled in this project exhibit trends indicating changes in the relative proportions of the cations, anions, or both (fig. 6). Longerterm pumping tests of these other wells could reveal results similar to those found for Pittsburg well 8.

\section{Conclusions}

The results of this study reflect the lateral variability in the chemical quality of the water within the Ozark aquifer transition zone described in Macfarlane and Hathaway (1987) and provide documentation of the effects of pumping on produced-water quality. The chemical character of water produced from the Ozark aquifer ranges from mixed cation-bicarbonate type for Pittsburg wells 8 and 10 and Crawford RWD 4 well 3 to a sodium-chloride type for Cherokee RWD 3 well 1 and other wells yielding even higher chloride concentration. As a group, water from the multi-aquifer wells with a chloride content less than $80 \mathrm{mg} / \mathrm{L}$ (Weir city well, Crawford RWD 5 well1, and about half of the Columbus well 4 samples) had a higher bicarbonate percentage and a lower sulfate and chloride percentage of total anions than water only from the Ozark aquifer. However, the much lower sodium and potassium percentage and higher calcium and magnesium percentage of total cations for the multi-aquifer wells than for samples from the Springfield Plateau aquifer suggest that the contribution of water from the Springfield Plateau aquifer is minor relative to the contribution produced from the Ozark aquifer. With the exception of Columbus well 4 and the Weir city well, variability in the chemistry of the monthly samples collected during 2006-08 was small for each site relative to the range among the sample sites.

Data for the chemical-quality pumping tests indicate that different zones within the Ozark aquifer produce waters of differing chemistries at variable rates to Pittsburg well 8 as it pumps. The general decrease in TDS and chloride concentrations relative to bicarbonate concentration indicates mixing of a relatively greater amount of ground water of low TDS concentration and of calcium, magnesium-bicarbonate type than of sodiumchloride type. Differences in the manner in which the bicarbonate/chloride ratio changed over time between the June and September tests suggest that vertical head gradients, both under pumping and nonpumping conditions, play an important role in the temporal pattern of changes in salinity during these pumping tests. Variability in the water chemistry of the monthly samples from most of the sites seems to be primarily related to the range in water quality within the Ozark aquifer. This may also be the main cause of changes observed in the water quality for the Columbus 4 and Weir city wells.

The results of this study compared with the results of the 1979-1980 sampling of Macfarlane and Hathaway (1987) indicate that Pittsburg well 10 and Crawford Consolidated RWD 1 well 2 have experienced long-term increases in chloride. Changes for the other sites from 1979-1980 to 2006-08 were either small or insignificant. Chloride concentration increase in water from wells in the Pittsburg area most likely has resulted from pumping stress associated with the higher density of high-yielding supply wells in southeastern Crawford County and the adjacent area of Missouri. It is possible that the changes in quality are influenced by local upconing of higher chloride, higher TDS, transition-zone water from deeper zones within the Ozark or the St. Francois aquifers. If the long-term increases in chloride concentration are linear with time, the earliest dates that Pittsburg wells 8 and 10 would produce water greater than the recommended drinking water limit of $250 \mathrm{mg} / \mathrm{L}$ are the years 2045 and 2060, respectively.

The variability in the chemical data from monthly sampling and the Pittsburg well 8 pump tests indicates that detection of long-term water-quality changes in the produced water from the wells within the transition zone will be difficult unless its variability over shorter time scales is factored into the analysis. To be successful, 1) water sampling events over the entire network and at individual well sites need to be more frequent to assess decadal changes and monthly variability and 2) the changes in water chemistry that occur under different levels of pumping stress during a single extended pumping event need to be considered in the analysis of trend. However, for these recommendations to more fully contribute to our understanding of the Ozark Plateaus aquifer system as a whole, attention needs also to focus on gathering vertical hydraulic-head profiles and water-quality pumping tests like those conducted in Pittsburg well 10 in existing and future wells. Data from these tests are a requisite for 
fully assessing the mechanisms that cause water-quality degradation in individual, open borehole wells.

\section{Acknowledgments}

This work was made possible by grant funds from the U.S. Geological Survey managed by the Kansas Water Resources Research Institute at Kansas State University, Manhattan, Kansas. The author wishes to acknowledge the assistance of Ed Reboulet with the fieldwork for this project and Rudy Ghijsen, Elizabeth Petroske, and Mike Magnuson of the KGS Analytical Services Laboratory for their careful analysis of the water samples collected for this project. The author also wishes to express appreciation to the operators of the water supplies that were sampled in this project. The author especially wishes to express his appreciation to Steve Gillis, City of Pittsburg, for his assistance that enabled the KGS to conduct the pumping tests on Pittsburg well 8. While working on this project, the author benefited from discussions with Walt Aucott, Mike Pope, and John Czarnecki of the U.S. Geological Survey on the work they were conducting on the Ozark aquifer in the Tri-state region. Margaret Townsend, Jim Butler, and Don Whittemore of the Kansas Geological Survey; Jim Vandyke of the Division of Geology and Land Survey, Missouri Department of Natural Resources; John Schumacher, Supervisory Hydrologist of the U.S. Geological Survey's Missouri Water Science Center; and Ralph Davis, professor and chair of the Department of Geosciences, University of Arkansas-Fayetteville, critically edited and reviewed the manuscript and provided helpful suggestions that solidified the ideas expressed in the manuscript and strengthened its overall message.

\section{References}

Darr, J. D., 1978, Geochemistry of ground water, southwestern Missouri: M.S. thesis, University of Missouri, 113 p.

Doveton, J. H., 1986, Log analysis of Arbuckle aquifer; in, Geohydrology of and Potential for Fluid Disposal in the Arbuckle Aquifer in Kansas, J. E. Carr, H. E. McGovern, and T. Gogel: U.S. Geological Survey, Open-file Report 86-491, p. 88-101.

Feder, G. L., Skelton, J., Jeffery, H. G., and Harvey, E. D., 1969, Water resources of the Joplin area, MO: Division of Geology and Land Survey, Missouri Department of Natural Resources, Water Resources Report 24, 97 p.

Gillip, J. A., Czarnecki, J. B., and Mugel, D. N., 2007, Potentiometric surfaces in the Springfield Plateau and Ozark aquifers of northwestern Arkansas, southeastern Kansas, southwestern Missouri, and northeastern Oklahoma, 2006: U.S. Geological Survey, Scientific Investigations Report 2007-5253, 25 p.

Hem, J. D., 1985, Study and interpretation of the chemical characteristics of natural water: U.S. Geological Survey, Water-Supply Paper 2254, 263 p.

Imes, J. L., and Emmett, L. F., 1994, Geohydrology of the Ozark Plateaus aquifer system in parts of Missouri, Arkansas, Oklahoma, and Kansas: U.S. Geological Survey, Professional Paper 1414D, 127 p.

Jorgensen, D. G., Helgesen, J. O., and Imes, J. L., 1993, Regional aquifers in Kansas, Nebraska, and parts of Arkansas, Colorado, Missouri, New Mexico, Oklahoma, South Dakota, Texas, and Wyoming - Geohydrologic framework: U.S. Geological Survey, Professional Paper 1414-B, 72 p.
Macfarlane, P. A., 2000, Revisions to the nomenclature for Kansas aquifers; in, Current Research in Earth Sciences: Kansas Geological Survey, Bulletin 244, part 2, http://www.kgs. ku.edu/Current/2000/macfarlane/macfarlane1.html.

Macfarlane, P. A., and Hathaway, L. R., 1987, The hydrogeology and chemical quality of ground waters from the lower Paleozoic aquifers in the Tri-state region of Kansas, Missouri, and Oklahoma: Kansas Geological Survey, Ground-water Series 9, 37 p.

Macfarlane, P. A., Whittemore, D. W., and Hathaway, L. R., 1981, A report to the Kansas Department of Health and Environment on the hydrogeology and chemical quality in the lower Paleozoic aquifers in southeast Kansas and adjoining areas of Missouri and Oklahoma: Kansas Geological Survey, Open-file Report 81-16, 48 p.

Piper, A. M., 1944, A graphic procedure in the geochemical interpretation of water analyses: American Geophysical Union, Transactions, v. 25, p. 914-923.

Pope, L. M., Mehl, H. E., and Coiner, R. L., 2009, Quality characteristics of ground water in the Ozark aquifer of northwestern Arkansas, southeastern Kansas, southwestern Missouri, and northeastern Oklahoma, 2006-07: U.S. Geological Survey, Scientific Investigations Report 20095093, 60 p.

Stramel. G. J., 1957, The hydraulic properties of the Ordovician rocks at Pittsburg, Kansas: Kansas Geological Survey, Bulletin 127, part 5, p. 153-178. 